\author{
UNIVERSIDADE DE SÃO PAULO \\ FACULDADE DE FILOSOFIA, LETRAS E CIÊNCIAS HUMANAS \\ DEPARTAMENTO DE LETRAS ORIENTAIS \\ PROGRAMA DE PÓS-GRADUAÇÃO EM LITERATURA E \\ CULTURA RUSSA
}

LUIZA NASCIMENTO ALMEIDA

\title{
A REPRESENTAÇÃO DA MORTE NA OBRA DE TOLSTÓI
}

SÃO PAULO 


\section{A REPRESENTAÇÃO DA MORTE NA OBRA DE TOLSTÓI}

Dissertação de Mestrado apresentada junto à Universidade de São Paulo - Faculdade de Filosofia Letras e Ciências Humanas, Departamento de Letras Orientais, Programa de Pós-Graduação em Literatura e Cultura Russa, para obtenção do título de Mestre.

Orientador: Prof. Dr. Noé Silva

Orientanda: Luiza Nascimento Almeida

\section{SÃO PAULO}

2011 
Autorizo a reprodução e divulgação total ou parcial deste trabalho, por qualquer meio convencional ou eletrônico, para fins de estudo e pesquisa, desde que citada a fonte.

Catalogação na Publicação

Serviço de Biblioteca e Documentação

Faculdade de Filosofia, Letras e Ciências Humanas da Universidade de São Paulo

Almeida, Luiza

A447r A representação da morte na obra de Tolstói / Luiza Almeida ; orientador Noé Silva. - São Paulo, 2011.

$119 \mathrm{f}$.

Dissertação (Mestrado) - Faculdade de Filosofia, Letras e Ciências Humanas da Universidade de São Paulo. Departamento de Letras Orientais. Área de concentração: Literatura e cultura Russa.

1. Lev Tolstói. 2. representação da morte. 3. morte na literatura. 4. literatura russa. 5. A morte de Iván Ilitch. I. Silva, Noé, orient. II. Título. 


\section{LUIZA NASCIMENTO ALMEIDA}

\section{A REPRESENTAÇÃO DA MORTE NA OBRA DE TOLSTÓI}

Dissertação de Mestrado apresentada junto à Universidade de São Paulo - Faculdade de Filosofia Letras e Ciências Humanas, Departamento de Letras Orientais, Programa de Pós-Graduação em Literatura e Cultura Russa, para obtenção do título de Mestre.

Orientador: Prof. Dr. Noé Silva

BANCA DE DEFESA

São Paulo, de de 20 


\section{AGRADECIMENTOS}

Difícil agradecer. Não que não haja uma multidão de pessoas a agradecer, mas, pelo contrário, porque sempre nos esquecemos de alguém nesse tráfego, e, inevitavelmente, uma lacuna fica ali na página em branco, para sempre sem preenchimento adequado. As regras, contudo, nos desafiam a fazê-lo. Por isso - que me perdoem possíveis omissões -, sintam a minha extrema gratidão em face da conclusão desse trabalho aqueles que aqui serão mencionados.

Primeiro agradeço ao querido professor Noé Silva, pela atenção e carinho que teve por essa forasteira recém-chegada de Niterói, Rio, à procura daquilo que mais amava: a literatura. Nesse sentido, agradeço também ao pessoal do Departamento de Letras Orientais da USP, sobretudo ao amável Jorge, que jamais se esquivou de orientar-me no que concerne à "papelada" e tudo mais.

Eis que, ingressa no mestrado, defrontei-me com aulas extraordinárias e professores de conhecimento irretocável. Lembro-me que, por diversas vezes, quis aplaudi-los ao final de suas palestras, mas jamais o fiz. Então o faço agora.

Impressionaram-me muito, apesar do contato restrito às aulas, o professor Marcus Mazzari (Dep. de Teoria Literária e Literatura Comparada), o professor Andrei Kofman (vindo da Rússia especialmente para passar um semestre conosco) e a professora Paula Montero (Dep. de Antropologia). Com relação àqueles com os quais tive um contato maior, agradeço de coração às sempre bem colocadas palavras, e mesmo às "broncas" embebidas em otimismo, da professora Elena Vássina e do professor Bruno Gomide, sem os quais teria sido impossível chegar até aqui. Por último, no que toca aos docentes, ou ao maior deles em nossa matéria, gostaria de deixar inscrito meu enorme apreço pelo professor Boris Schnaiderman, que, sábio e guerreiro, vez por outra aparece na USP, humilde como sempre, para nos brindar com aulas de valor inestimável.

E como não agradecer aos amigos "paulistas" que fiz ao longo dessa jornada? Maged El Gebaly, Ali Karakas, José Araújo, Andrea Dama, dentre outros, foram, sempre que possível, formidáveis. Pelas divertidas aulas de russo, agradeço à querida Katia Volkova e a seus anjinhos. À Natalia Quintero, um “muito obrigada” pela bela tradução de Os diários de juventude de Liev Tolstói, que me foram tão úteis. Pela 
amizade que já dura quase um par de décadas, faço uma menção à Maíra Vasconcelos, essa flor de ser humano, no sentido mais tolstoiano do termo, e ao Érico, amaríssimos que estiveram comigo desde o começo. E claro, não poderia deixar de expressar todo meu carinho à amiga Anastássia Bytsenko, a Nástia, sem à qual minha vida em São Paulo teria sido um tumulto ainda maior. Agradeço sua hospitalidade, seu "russo", suas palavras sóbrias e reconfortantes e sua doce lealdade diante de tudo aquilo que acredita.

Agradeço também à Fundação de Amparo à Pesquisa do Estado de São Paulo (FAPESP) pelo crédito dado ao trabalho; e, por fim, à Universidade de São Paulo - esse magnífico oásis em meio a uma difícil cidade. 
Ao meu avô Olivier Almeida (in memorian). Ao meu tio-avô Jorge da Paz Almeida (in memorian). Ao João Ricardo, meu amorzinho lindo. Aos meus meninos do coração: Miguel Masella e Bruno Ruivo. Aos meus pais. À vida em paz. 
De tanto acumular mistérios nulos e monopolizar o sem sentido, a vida inspira mais pavor do que a morte: é ela a grande Desconhecida. Aonde pode levar tanto vazio e incompreensível? Nós nos apegamos aos dias porque o desejo de morrer é demasiado lógico, portanto ineficaz. Porque se a vida tivesse um só argumento ao seu favor - distinto, de uma evidência indiscutível -, se aniquilaria; os instintos e os preconceitos desvanecem-se ao contato com o Rigor. Tudo o que respira se alimenta do inverificável; um suplemento de lógica seria funesto para a existência - esforço até o Insensato... Dê um objetivo preciso à vida: ela perde instantaneamente seu atrativo. A inexatidão de seus fins a torna superior à morte - uma gota de precisão a rebaixaria à trivialidade dos túmulos. Pois uma ciência positiva do sentido da vida despovoaria a terra em um dia; e nenhum frenético conseguiria reanimar a improbabilidade fecunda do Desejo.

Cioran

Vai... abandona a morte em vida em que hoje estás Ao lugar onde essa angustia se desfaz E o veneno e a solidão mudam de cor Vai indo amor...

Taiguara

Se eu tiver que morrer Vou morrer pela vida!...

Vinicius de Moraes

Quem quiser comigo ir Tem que vir do amor Tem que ter pra dar... 


\section{RESUMO}

O trabalho ambiciona expor como se efetua a representação da morte na obra de Lev Tolstói. Não há, entretanto, uma análise da totalidade de sua obra, o que seria impossível em face do espaço reservado, mas o exame de uma amostra de três de suas narrativas-cânone a respeito da morte: A Morte de Iván Ilitch, Senhor e Servo e Três Mortes; textos que dialogam entre si. Nesse sentido, a pesquisa também disserta sobre as inter-relações existentes entre a morte e a criação literária, pautando-se em textos de Mikhail Bakhtin e Maurice Blanchot; e aponta os principais acontecimentos de morte na vida de Lev Tolstói, responsáveis por definir sua personalidade dualista e, em um segundo momento, conduzi-lo à conversão, processo narrado no fragmento Uma confissão.

Palavras-chave: Lev Tolstói; morte na literatura; A morte de Iván Ilitch. 


\begin{abstract}
The paper aims to show how the representation of death is done in the work of Lev Tolstoy. There isn't, however, an analysis of all of his work, which would be impossible face to the place settled, but the examination of a sample of three of its canon-narratives related to death: The Death of Ivan Ilyich, Master and Man and Three Deaths; texts that talk to one another. In this sense, the research also talks about the interrelations between literary creation and death, basing on texts by Mikhail Bakhtin and Maurice Blanchot, and highlights the main events of death in the life of Lev Tolstoy, responsible for defining his dualistic personality, and latter on, lead him to conversion, a process exposed in the fragment Confession.
\end{abstract}

Key-words: Lev Tolstoy; Death in literature; The Death of Ivan Ilyich. 


\section{SUMÁRIO}

INTRODUÇÃO

1. MORTE E CRIACÃO

1.1.A morte do outro 14

1.2.A morte de si mesmo 18

2. MORTE E VIDA EM TOLSTÓI

2.1.Mortes em família 23

2.2.Uma personalidade em conflito 28

2.2.1. Outra abordagem 32

2.2.2. Memórias 33

2.2.3. Diários de juventude $\quad 35$

$\begin{array}{ll}\text { 2.3.Uma confissão } & \mathbf{3 7}\end{array}$

2.3.1. Gatilhos iniciais $\quad 38$

2.3.2. O episódio de Arzamás $\quad 40$

2.3.3. Desespero, suicídio e busca da possibilidade $\quad 42$

2.3.4. Solução para o enigma da morte: união do finito ao infinito 46

2.4.A própria morte $\quad 51$

3. MORTE E OBRA EM TOLSTÓI

3.1.Observações gerais $\quad 57$

3.1.1. O discurso monológico de Tolstói - Retornando a Bakhtin 57

3.1.2. Deus, o amor, a vida, o outro e o bem 61

3.2.A morte de Iván Ilitch

3.2.1. Capítulo Um 62

3.2.2. Uma personagem sempre "agradável" e "apropriada" 67

3.2.3. A desumanização de Iván 70

$\begin{array}{ll}\text { 3.2.4. Quando a morte é a vida } & 75\end{array}$ 
3.3.Senhor e servo

3.3.1. Relações $\quad 86$

3.3.2. A jornada $\quad 88$

3.3.3. Da perdição à salvação $\quad 90$

3.3.4. Imagens 95

3.4.Três mortes 97

3.4.1. Rousseau $\quad 98$

3.4.2. A história 103

4. CONSIDERACÕES FINAIS

4.1. Somos todos "Iváns Ilitchs"? 110

5. BIBLIOGRAFIA 115 


\section{INTRODUÇÃO}

Nosso interesse em Lev Tolstói está claro: trata-se de um dos maiores escritores da literatura universal. Nosso interesse na morte, no entanto, é obscuro, embora corajoso, alguns diriam, se formos nos ater à reputação adquirida por esse "evento" que a todos acomete, por sinal, na sociedade contemporânea: a pior possível. O medo da morte é das mais terríveis mazelas que, insidiosamente, aflige o homem nos dias de hoje.

Philippe Ariès remonta a origem desse medo ao século XIX, quando as representações da morte cessaram, e uma gélida angústia, advinda do medo da morte aparente - decorrente da diminuição quase total das funções vitais, ainda que o homem não estivesse morto - se tornaria freqüente. Esse pavor se mostrou de tal forma profundo, que a morte passou a ser expressa por meio de silêncios, reticências, gritos mudos - o "que significa que ela rompeu seus grilhões e se tornou uma força selvagem e incompreensível"1. Tolstói estava estatelado no cerne dessas mudanças. Por isso, unir o escritor à morte - o que pode parecer, a princípio, um tanto ousado ou demasiado fúnebre -, é para todos os que tenham um mínimo de intimidade com a obra e a vida do autor, perfeitamente coerente, pois sabem que esse caminho só poderá redundar na vida - e esta é a nossa hipótese principal -, já que, vagando pelos interstícios da danação, Tolstói tentaria desbravar o segredo do bem-viver.

A questão que nos faremos, portanto, é a seguinte: Como se efetua a representação da morte na obra de Tolstói? A partir daí, teremos um longo caminho por percorrer até desembocarmos em alguma conclusão efetiva.

Em um primeiro capítulo, investigaremos o papel da morte sob um âmbito mais geral: a criação literária - o que será, por bem, concernente a todos aqueles que se entregam ao ofício de escrever. No segundo capítulo, particularizaremos o tema, sondando as antecâmaras da vida de Tolstói: sua relação com alguns membros da família, as mortes ocorridas nesse grupo, sua personalidade dualista, seu processo de conversão e, por último, a sua morte. De posse desse conhecimento, não iremos, por fim, examinar toda a obra do autor, o que não seria de forma nenhuma possível no espaço a nós destinados, mas acompanhar alguns de seus personagens em três "jornadas de descoberta", como aponta Gustafson: A Morte de Iván Ilitch, Senhor e Servo e Três

\footnotetext{
${ }^{1}$ ARIÈS, Philippe. História da Morte no Ocidente. Rio de Janeiro: Ediouro, 2003. p. 159
} 
mortes. Essas narrativas-cânone sobre a morte em Tolstói, esperamos, derribarão muitas das dúvidas que temos com relação à questão proposta, corroborando o que já dissemos: por meio da morte, em Tolstói, alçamo-nos à vida real. O sentido da palavra morte, neste contexto, irá deslocar-se até, enfim, perder-se, deixar de ser.

Esperamos, igualmente, fazer jus à tarefa à qual nos propusemos, iluminando, como Lev Tolstói, por meio desse passeio à beira do precipício, os maiores enigmas referentes à vida - esta pela qual caímos, levantamo-nos e batalhamos auroras a fio sem saber exatamente o porquê. 


\section{1.}

\section{MORTE E CRIAÇÃO}

Neste capítulo inicial, a intenção é percorrer as obras de Mikhail Bakhtin e Maurice Blanchot, pensadores que se dispuseram a teorizar a respeito do papel da morte no âmbito da criação literária. Desse modo, em vez de nos enveredarmos antecipadamente pelo principal conteúdo do trabalho, poderemos balizar a pesquisa sobre um parâmetro prévio e mais consistente, com o fito de detectar, nesse tráfego, o modus operandi, por meio do qual o elemento morte funciona em face das circunstâncias que movem o ânimo do escritor.

\subsection{A morte do outro}

Em Estética da Criação Verbal, Mikhail Bakhtin (2006) disserta, entre outras coisas, sobre o imprescindível valor literário da morte. Esta entraria na fundamentação da criação literária, na espinha dorsal do texto, nas preliminares do ato criativo, sendo parte das relações travadas pelo homem antes que possa debruçar-se sobre qualquer iniciativa de estetizar a vida. A morte estaria, dessa maneira, vinculada originariamente à concepção artística. Mas como, afinal, Bakhtin descreve esse processo no qual o evento da morte tem um papel preponderante?

Primeiramente, o autor diferencia a percepção que temos da morte do outro em nós mesmos da percepção que temos da nossa própria morte em nós mesmos. Ou seja, diz que vivenciar o sofrimento do outro em mim seria algo totalmente distinto "do sofrimento dele para si próprio e do meu próprio sofrimento em mim"2. Ele denomina essa vivência do outro em mim de compreensão simpática, ressaltando que ela precipitaria a formação da vida interior do outro (da existência do outro, da alma do outro) na autoconsciência, assim como a imagem física do outro, de seu corpo e características exteriores também toma forma na autoconsciência.

Sabemos, no entanto, que, para efetivar o desenho de uma forma, é preciso haver limites bem traçados, a fim de que seja possível distinguir a imagem do universo a que

\footnotetext{
${ }^{2}$ BAKHTIN, Mikhail. Estética da Criação Verbal. Tradução do russo: Paulo Bezerra. São Paulo: Martins Fontes, 2006. p. 94
} 
ela pertence, individualizando-a em nossa consciência. Por isso, no caso do desenho da alma, essas fronteiras também precisam estar bem claras, devidamente finalizadas, ou então não haverá enformação adequada na consciência. De que fronteiras, contudo, estamos falando? "Antes de tudo" - esclarece Bakhtin - "fronteiras temporais" ${ }^{3}$. As fronteiras da vida interior, portanto, traduzir-se-iam especialmente pelos termos do nascimento e da morte, marcadores do princípio e do fim da vida - do tempo. Só através dessa apreensão é possível determinar o conteúdo valorativo da vida de uma pessoa, o significado e sentido de uma existência.

Interessante pensar, entretanto, que na vida por mim vivenciada - a minha vida não é possível estar consciente dos eventos do meu nascimento e da minha morte. Vivemos, sobretudo, ao compasso de sonhos e projetos futuros, ignorando quando, afinal, vamos morrer. Disso inferimos a impossibilidade de delinear a nossa própria alma na autoconsciência. Por isso, Bakhtin diferencia alma, a maneira que vivencio a vida interior do outro, de espírito, que corresponderia àquilo que vivo em mim mesmo. A alma seria "o conjunto de todo o efetivamente vivenciado"4 "o peso emocional da vida em seu conjunto"5 concluído, fechado, sepultado, que já pode ser considerado em sua integridade porque está morto, acabado: nada além pode ser agregado ou somado a essa vida em particular. Passível de ser analisada como um todo, a alma, com efeito, é a vida do outro.

No campo do espírito, segundo Bakhtin, não há os elementos indispensáveis à esfera da alma - esta que esculpimos em nossa mente.

Os valores de uma pessoa qualitativamente definida são inerentes apenas ao outro. Só com ele é possível para mim a alegria do encontro, a permanência com ele, a tristeza da separação, a dor da perda, posso encontrar-me com ele no tempo e no tempo mesmo separar-me dele, só ele pode ser e não ser para mim. Eu estou sempre comigo, não pode haver vida para mim sem mim $^{6}$.

Por isso, ao contrário do que emerge de nossa relação com o outro, é disparatada a idéia de viver a minha vida após a minha morte, dando continuidade à vivência do enredo de um mundo destituído de mim. Tal hipótese, de tão absurda, pode ser apenas

\footnotetext{
${ }^{3}$ Ibidem. p. 95

${ }^{4}$ Ibidem. p. 101

${ }^{5}$ Ibidem. p. 96

${ }^{6}$ Ibidem. p. 96
} 
contemplada no espaço da ficção, no qual a suspensão de descrédito ${ }^{7}$ é a norma. Um exemplo é o filme A Felicidade não se compra, de Frank Capra, no qual o protagonista George Baley, na iminência de cometer suicídio, é brindado com a chance de testemunhar a existência do mundo em que viveu caso ele não tivesse existido e, a partir disso, imputar valor à própria vida. Examinando a história sob a perspectiva bakhtiniana, porém, saberíamos que, se ele não tivesse existido, esse mundo a ele relegado não teria existido também. A vida real não concede ao espírito tais cortes de caminho. Não possuímos, nessa trilha, a visão do conjunto de nossas vidas, já que nunca poderemos apreender o significado daquilo que lhe denota um contorno: a nossa própria morte. Ou seja: "posso justificar e concluir esteticamente o outro mas não a mim mesmo" 8 .

Sob esse prisma, Bakhtin atrela ao âmbito da vida-morte das pessoas o sentido e a importância da minha vida, uma vez que os termos desta não podem figurar como enredo, ou seja, que ela não existe como totalidade para mim. "Minha vida é a existência que abarca no tempo as existências de outros" ${ }^{9}$. Esse cenário nos leva a deduzir que, não podendo vivenciar o tempo emocionalmente condensado que engloba a minha vida, não posso fazer dela um enredo, uma história, algo que possa ser esboçado em sua inteireza, a não ser que esse "eu" se converta em "outro", cujas lacunas eu preencho com a minha imaginação, inventando a morte - ainda assim, cabe frisar, será “outro" e não "eu”. Em face disso, Bakhtin refere-se "às comparações factuais da visão de mundo da personagem e do autor e as explicações de uma pela outra"10 como inconsistentes. A espécie de comparação que se faz entre Tolstói e Liévin, por exemplo, personagem do romance Anna Kariênina, torna-se inútil e equivocada, se ignorada "a diversidade essencial de planos de conjunto da personagem e do autor" ${ }^{11}$. São, a bem dizer, conteúdos pertencentes a dimensões completamente distintas. Como já vimos, um é espírito, o outro é alma. Um é autor, o outro é personagem - vida cuja imagem foi devidamente talhada pela morte.

Percebendo o outro sob o signo da morte, portanto, é que passamos ao acabamento estético dele, o que se delineia por meio da memória. Após a morte do

\footnotetext{
${ }^{7}$ Suspensão de descrédito ou suspension of disbelief, em inglês, foi um termo cunhado por Samuel Taylor Coleridge para designar o uso de elementos fantásticos ou não realistas em trabalhos de ficção.

8 Ibidem. p. 97

9 Ibidem. p. 96

${ }^{10}$ Ibidem. p. 8

${ }^{11}$ Ibidem. p. 8
} 
outro, diferentemente do que ocorre após a morte de mim mesmo, a enformação da alma tem prosseguimento na autoconsciência - ou seja, é possível contemplar a continuidade do mundo a despeito da inexistência do outro. Instituindo o fim de uma existência, temos como manuseá-la e com ela trabalhar, moldando o barro conforme a quantidade de barro que possuímos, pois se trata de uma vida que já não será irrigada por nenhuma surpresa que the modifique o significado - a lição dada pela anedota final. Tenho, assim, toda a vida do outro em minhas mãos. Nesse ponto, é construída "sua personalidade, sua consolidação e seu acabamento numa imagem esteticamente significativa" ${ }^{\prime 2}$. Isto é, sob determinado aspecto, ocorre a criação da personagem, esse ente finalizado por mim esteticamente segundo um sentido que a mim foi dispensado na esteira de sua morte. Um exemplo bastante literal é o romance "não-ficcional" A sangue frio do jornalista Truman Capote. No processo de finalização do livro-reportagem, baseado ipsis litteris no assassinato real de uma família em Holcomb, Kansas, Capote viu-se diante de um fato que o fez interromper a obra: os anti-heróis, os assassinos do enredo que costurara, ainda não haviam sido enforcados. Uma reviravolta no caso poderia acontecer enquanto eles estivessem vivos, reconfigurando toda a trama. Por isso, Capote não só desejou a morte dos amigos confidentes Perry e Richard, como teve de esperar quatro longos anos até que os criminosos sofressem a pena capital, e ele, enfim, pudesse terminar seu livro, lançado em 1966. "A memória da vida finda do outro possui a chave de ouro do acabamento estético do indivíduo" 13 - aponta Bakhtin. Tolstói parece estar perfeitamente ciente disso ao registrar, em 1890, em seu diário: "Mesmo que velho ou doente, mesmo que você tenha feito muito ou pouco, a missão completa de sua vida não só não terminou, mas ainda não recebeu seu significado decisivo e final até o último suspiro". ${ }^{14}$

O espírito, portanto, "não pode ser agente do enredo", visto que para o espírito não existe nenhum enredo, uma vez que a consciência da morte lhe é negada. A vida que vivencio é uma existência aberta, inconclusiva, não-mensurável emocionalmente, e não há, em razão disso, fronteiras de onde se possa partir e aonde se possa chegar, extraindo, nesse âmbito, um sentido.

\footnotetext{
12 Ibidem. p. 98

13 Ibidem. p. 98

${ }^{14}$ TOLSTÓl apud GUSTAFSON, Richard F. Leo Tolstoy - Resident and Stranger. Tradução minha. New Jersey: Princeton University Press, 1986. p. 6

${ }^{15}$ BAKHTIN, Mikhail. Op. cit. p. 99
} 


\begin{abstract}
A determinidade interna - a carne mortal do sentido -, que nasce e morre no mundo, inteiramente dada no mundo e no mundo acabada, reunida num objeto finito, pode ter significado de enredo e ser personagem. $^{16}$
\end{abstract}

Para Bakhtin, a primeira condição para uma abordagem estética do mundo é compreendê-lo como o mundo dos outros que nele concluíram suas vidas. "Preciso me afastar de mim para libertar o herói para o livre desenvolvimento do enredo no mundo"17. O enredo, a forma e o ritmo só podem adquirir "vida" após a morte. Caryl Emerson (1985) enfatiza que apenas a morte pode tornar o outro disponível, sendo uma espécie de "presente"18. Este presente (a totalidade do outro), no entanto, cobra um preço, para a maioria das pessoas, excessivamente alto, embora inevitável: a perda de um ente querido.

Nosso principal objeto de estudo neste trabalho, portanto, a morte, está tanto na obra de Tolstói quanto no legado de qualquer artista em níveis imponderavelmente mais sutis, remontando ao ato da pré-criação, repercutindo a própria noção de origem, das formas das coisas, palpitando nas profundezas instáveis do texto, e não sendo apenas mais um elemento superficial de uma dada narrativa. Mais adiante, quando analisarmos algumas obras de Tolstói, veremos de que forma a teoria de Bakhtin e suas reflexões sobre a morte interagem com ela.

\title{
1.2 A morte de si mesmo
}

Maurice Blanchot, em $O$ espaço literário, faz uma extensa reflexão sobre a questão da morte e da criação literária. Contudo, nós nos ateremos, aqui, somente aos pontos mais relevantes.

Blanchot parte de um trecho extraído do Diário de Kafka, cujo sentido se resume na seguinte frase: "o que escrevi de melhor fundamenta-se nessa aptidão para poder morrer contente"19. Mas o que significaria "morrer contente"? Significaria que a morte,

\footnotetext{
${ }^{16}$ Ibidem. p. 101

17 Ibidem. p. 102

${ }^{18}$ EMERSON, Caryl. The Tolstoy Connection in Bakhtin. Tradução minha. PMLA, Vol. 100, no 1. Modern Language Association, 1985. p. 74. Disponível em: <http://www.jstor.org/stable/462201>. Acesso: 20/06/2001.

${ }^{19}$ KAFKA apud BLANCHOT, Maurice. O espaço literário. Rio de Janeiro: Editora Rocco, 2011. p. 93
} 
no caso, deixa de ser um claustro, um lugar de desespero, onde não se pode criar senão sob seu jugo, para tornar-se um veículo que conduz o escritor rumo à liberdade, desde que, a bem dizer, se estabeleça com ela relações de soberania. "Kafka sente aqui profundamente que a arte é relação com a morte" ${ }^{20}$. Segundo Blanchot, isso ocorre porque a morte é o extremo.

Dessa forma, se o escritor dispõe da morte, não estabelecendo com ela uma relação de medo e submissão, dispõe integralmente de si mesmo, "é integralmente poder" ${ }^{21}$, senhor de si perante a idéia de fim. Uma relação submissa com a morte, por outro lado, instauraria o pânico que assomou por anos Tolstói. Como veremos mais adiante de forma pormenorizada, Tolstói cultivou tanta obsessão pela morte (ou pela busca de um sentido para a vida), que sua arte passou a desenvolver-se em função dela, trilhando um caminho por ela indicado, e tornando-o, de certa maneira, um prisioneiro de tal neurose. O russo precisava, então, descobrir o sentido de uma vida cuja morte ficasse em segundo plano. Ou a vida faria algum sentido além da morte, ou ela não valeria a pena.

Morrer contente, desse modo, seria encontrar nesse "negativismo extremo, na morte convertida em possibilidade"22, uma total satisfação. O bem escrever, aqui, estaria atrelado ao bem morrer. Nessa trilha, as concepções de Bakhtin se aproximam das de Blanchot, uma vez que em ambas a morte é apresentada como condição para a criação. Na primeira, a morte do outro; na segunda, a morte de si mesmo.

Blanchot então reconhece que "o escritor (...) é aquele que recebe o seu poder de escrever de uma relação antecipada com a morte." ${ }^{23}$ A partir desse mote, ele também sugere que escrever é um meio de não morrer, ou seja, de perpetuar-se na perenidade da obra "ao abrigo da morte" 24 . Deleitando-se na posteridade, a obra concederia essa possibilidade, esse gostinho de eterno ao escritor, sendo, portanto, aclamada como história. O papel do escritor, por sua vez, seria louvável, segundo Blanchot, se ele passasse ao anonimato no intuito de cooperar para a transformação do mundo, substituindo o mesquinho egocêntrico pela verdade profunda e sem autoria.

\footnotetext{
${ }^{20}$ BLANCHOT, Maurice. Op. cit. p. 93

${ }^{21}$ Ibidem. p. 93

22 Ibidem. p. 94

${ }^{23}$ Ibidem. p. 96

${ }^{24}$ Ibidem. p. 97
} 
Esses sonhos tão fortes, ligados a uma transformação da arte em que esta ainda não está presente em si mesma, mas em que o homem que se crê senhor da arte quer tornar-se presente, ser aquele que cria, ser, ao criar, aquele que escapa, nem que seja um pouco, à destruição, possuem de impressionante o seguinte: eles mostram os "criadores" empenhados em uma relação profunda com a morte (...). ${ }^{25}$

De acordo com Blanchot, mantendo a morte a distancia ou dominando-a, podemos travar com ela uma relação de liberdade, essencial ao criador. Relação tão buscada por Tolstoi, que, ao longo de sua vida, ele acabou permitindo que a morte o guiasse pelas artérias da própria obra - o que Petr Bitsilli vai elucidar muito bem -, convertendo-se, por conseguinte, como profere Emerson à luz de Bakhtin, em um "poeta da morte" 26 . Por outro lado, contudo, essa estranha relação de submissão que Tolstói mantinha com a morte instigava tremendamente seu intelecto, levando-o a produzir prolificamente. Bitsilli observa com exatidão que "diferente do maníaco comum, seu foco [na morte] agia de maneira mais a fortalecer seus poderes criativos do que a enfraquecê-los"27. Boris Schnaiderman complementa a assertiva: "Se é verdade que os seus escritos puramente argumentativos não se comparavam em criatividade e poder de sedução às obras ficcionais, o "pathos" do pregador muitas vezes imprime intensidade e veemência ao texto literário.,"28

Blanchot salienta que a busca da possibilidade da morte (ou seja, poder morrer tendo estabelecido uma relação de liberdade com a morte; ou por que o evento da morte foi burlado por meio da inscrição do nome do autor na obra, cuja eternidade está garantida), da aceitação da morte, é algo inerente ao homem, sendo, contudo, significativa apenas quando se torna uma necessidade. No âmbito da religião, entretanto, a morte deixa de ser "o paradoxo de um fato brutal sem verdade" ${ }^{29}$ para tornar-se um espaço onde o "verdadeiro teria sua origem" 30 , alicerçado em uma relação transcendental com outro universo. Tolstói, para quem a busca da possibilidade da morte era uma necessidade da qual dependia sua vida, também se esgueirou por esse

\footnotetext{
${ }^{25}$ Ibidem. p. 98

${ }^{26}$ EMERSON, Caryl. Op. cit. p. 68

${ }^{27}$ BITSILLI apud HARRIS, Jane. A Humanist Reading of Tolstoy: The writings of Petr H. Bitsilli. Tradução minha. Tolstoy Studies, Vol. 4, Toronto: Tolstoy Society of North America, 2001. p. 73

${ }^{28}$ SCHNAIDERMAN, Boris. O legado de Tolstói. Folha de São Paulo, 9 de dez. de 2000. Jornal de Resenhas, no 69, p. 10.

${ }^{29}$ BLANCHOT, Maurice. Op.cit. p. 99

${ }^{30}$ Ibidem. p. 99
} 
caminho da verdade, de tom claramente epifânico, como forma de encontrar uma solução para seu tormento, sobretudo quando em sua vida e obra se dá o evento da "iluminação", da revelação pré-morte, no qual seus personagens (e Iván Ilitch é o mais representativo dessa tendência), prestes a sucumbirem, deparam com um estado que lhes descortina a verdade - uma verdade invariavelmente expressa pelo amor. Da morte, portanto, decorre a vida, o sentido da vida - na acepção mais estrita da palavra "sentido", ou seja, a de uma direção por seguir.

Blanchot não poderia deixar de tocar também no tema do suicídio, que nada mais é do que a morte voluntária. Esta seria, sob certo aspecto, a morte mais humana, ou mais "honrada", como sugere Tolstói em Uma confissão. Segundo o pensamento desenhado pelo autor francês a partir de Kirílov, personagem do romance Os Demônios de Dostoiévski, o suicídio é como um balão de oxigênio ao alcance da mão, já que a morte, nestes termos, "torna a vida possível" ${ }^{31}$. Da mesma forma, o suicídio traz em si o sabor da liberdade, uma vez que se trata de um ato que vai de encontro àquilo que nos aprisiona: o medo, o mistério, o absoluto concernente a Deus. Com o suicídio, Kirílov visa a obter uma prova sem a qual se angustia - a prova da inexistência de Deus. Ele se rebela contra o absoluto representado pela divindade e almeja libertar-se. "Se ele morre livremente, se experimenta e prova a si mesmo sua liberdade na morte e a liberdade de sua morte, terá atingido o absoluto, ele será esse absoluto, absolutamente homem, e não haverá absoluto fora dele" 32 - explica Blanchot. O suicídio de Kirílov significaria, com efeito, a morte de Deus, desonerando o homem do medo e libertando a vida no rastro de uma morte possível. O medo da morte, para Kirílov, seria a origem de Deus. Por isso, derrotando esse medo por meio da própria morte, ele estaria livrando a humanidade d'Ele.

O problema, contudo, estaria calcado em descobrir se o suicídio é de fato uma possibilidade, já que ao acreditar no poder de dominar a morte, o homem pode estar sendo, a bem dizer, dominado por ela. Isso leva-nos a refletir a respeito de outra forma de domínio da morte, que consiste basicamente na indiferença, quando "Morrer bem significa morrer com decência, coerente consigo mesmo e no respeito dos vivos" ${ }^{33}$. Sob esse prisma, a boa morte se consagraria em morrer em nossa própria vida "de costas

\footnotetext{
${ }^{31}$ Ibidem. p. 101

32 Ibidem. p. 101

33 Ibidem. p. 105
} 
para a morte" ${ }^{34}$, demonstrando generosidade em relação ao mundo, em vez de uma escandalosa deferência pelas dimensões do abismo de onde ecoa a palavra "fim". Em $A$ morte de Iván Ilitch, vemos a personagem principal, a despeito dos obstáculos que enfrenta, e do desconcerto mental que o assola, caminhar no momento final para uma boa morte regada a coerência e doçura. Nikita, o servo de Senhor e Servo, tem esses valores inerentes a si e a ameaça da morte não lhe causa medo. $\mathrm{O}$ mesmo ocorre em Três mortes, quando Tio Khviédor deixa o mundo de forma a incomodar o mínimo possível àqueles que ficam, enquanto estes conferem à sua morte apenas o que ela naturalmente requer: dignidade.

Nessa linha de raciocínio, Blanchot observa que a certeza de que o homem morre não é nada, se comparada com a certeza de que ele é a partir de sua morte. Mediante a proposição de Bakhtin que, por outro lado, revela a importância primordial da morte do outro no ofício do escritor, podemos concluir que este é, em sua trajetória, duplamente dependente da morte. Cabe a ele guiar com bom senso, quando lhe for permitido, os avanços desse veleiro batizado de "Жизнь" 35 .

\footnotetext{
${ }^{34}$ Ibidem. p. 105

${ }^{35}$ Vida.
} 


\section{2.}

\section{MORTE E VIDA EM TOLSTÓI}

Como vida e obra em Tolstói se desenvolveram juntas, uma reportando-se à outra - qual o artista reportava-se ao moralista e o Residente ao Estrangeiro -, nosso propósito, neste segundo capítulo, é fazer uma reflexão sobre como a morte se tornou o maior enigma na vida do autor - repercutindo, por conseguinte, em sua obra. Por que seu intelecto se tornara tão avesso a ela? Que havia nesse alvo que repelia todo e qualquer projétil que o autor ambicionasse nele cravar? Nesse contexto, também investigaremos em que medida a morte se fez presente em sua longa trajetória (ressaltando as mudanças nessa relação) ao propiciar um sem-número de emoções e ações concretas, de forma a moldar, por conseguinte, uma grandiloqüente personalidade.

\subsection{Mortes em família}

Tão logo chegou ao mundo, Tolstói recebeu sobre sua tez delicada uma lufada da brisa fria da morte. Perdia, em 30 de agosto de 1830, o maior elo que possuía com o mundo até então: sua mãe, a Condessa Maria Nikoláievna Tolstáia. A despeito de não lembrar-se desse momento específico, quando estava prestes a completar dois anos, durante toda a vida Tolstói sofreria pela falta dessa mãe e buscaria esse amor, ainda que os esforços da tia Toinette ${ }^{36}$ para substituí-lo fossem enormes. Essa primeira morte (que se tornaria também a primeira morte de sua ficção ${ }^{37}$ ) significativa em sua existência recém-consolidada moldaria um ser humano intenso, carente, dramático, sulcado por uma torpe cicatriz arregaçada no peito. Poucos anos antes de morrer, ele teria escrito: “eu passeio pelo jardim e penso na minha mãe, em Mamãe; eu não me recordo dela, mas ela sempre foi um ideal de santidade para mim" 38.

O pai de Tolstói, Nikolai Ilitch Tolstói, morreria no dia 21 de junho de 1837, quando o filho tinha oito anos, de um ataque de apoplexia no meio da rua. Sobre o

\footnotetext{
${ }^{36}$ Tatiana Aleksandrovna Ergolskaia era a tutora de Tolstói e de seus irmãos. Ela morreu em 1874 aos 79 anos.

${ }^{37}$ Tolstói descreveria a morte da mãe em Infância.

${ }^{38}$ TOLSTÓl apud TROYAT, Henri. Tolstoy. Tradução minha. New York: Grove Press, 1967. p. 14
} 
episódio, Tolstói teria registrado: "Eu amei muito meu pai. (...) Mas eu não havia aprendido o quão grande era esse amor até a sua morte" 39 . A morte do pai aguçou no menino uma sensação que já lhe era proeminente - a sensação de abandono, de orfandade, de falta. Pouco tempo depois, em maio de 1838, a avó do escritor morreria, extinguindo os laços familiares primários.

Um profundo senso familiar, na verdade, capturara o autor desde a mais tenra idade. A experiência da "irmandade das formigas", ocorrida quando Tolstói tinha cerca de cinco anos, expõe com exatidão esse vestígio de afeição pueril. Trata-se de um jogo simples inventado pelo arteiro Nikolai e levado a cabo pelos irmãos. O jogo portava, contudo, um segredo redentor, cuja revelação faria a humanidade feliz, ao erradicar a doença, a miséria e a raiva: "todos deveriam amar uns aos outros e se tornar "irmãos formigas" $" 40$. O segredo estava inscrito em uma vareta verde soterrada à beira de uma ravina na floresta Zakaz. Mesmo destituídos da vareta, os meninos, encantados com a história, passaram a brincar de "irmandade das formigas", o que consistia em "enterrarse" por debaixo de cadeiras cobertas com xales e ficar por ali, aninhados, aconchegados, protegidos, compartilhando do afeto e ternura uns dos outros. Certo de que Nikolai não dissera aquilo em vão, pois suas intenções eram sempre as melhores, Tolstói solicitou ser sepultado no mesmo lugar onde se encontrava a vareta verde, com o propósito de, igualmente, homenagear o irmão pelo qual alimentava enorme admiração - e seu desejo foi assim realizado.

Em decorrência disso, Petr Bitsilli, ao comparar Tolstói com outros escritores compatriotas, como Turguêniev e Gontcharov, "que não tinham família" 41 , caracteriza Tolstói como um "homem de família" da vasta propriedade que herdara ou, seguindo um rastro mais "humano", de seus irmãos legítimos: Dmítri, Nikolai, Serguei e Maria.

Dmítri Tolstói, como registrado em Uma Confissão, experimentou em vida um período de envolvimento religioso inflamado - não só venerando a Deus, mas observando todos os preceitos, por mais rígidos que fossem, instaurados pela Igreja Ortodoxa. Ateve-se, nesse rastilho, a uma vida imaculada e dentro dos princípios da moralidade, privando-se do consumo do álcool, do tabaco e da prática de relações

\footnotetext{
${ }^{39}$ TOLSTÓl apud TROYAT, Henri. Op. cit. p. 28

${ }^{40}$ GUSTAFSON, Richard F. Leo Tolstoy - Resident and Stranger. Tradução minha. New Jersey: Princeton University Press, 1986. p. 8

${ }^{41}$ HARRIS, Jane. Op. cit. p. 74

42 Ibidem. p. 74
} 
sexuais. Tal austeridade conferiu-lhe a alcunha de Noé. Sua personalidade, contudo, tornava-se explosiva, caso zombassem de sua fé. Em suas Reminiscências ${ }^{43}$, escritas em idade avançada entre 1902 e 1906, Tolstói declara ter amado Dmítri de uma forma simples e natural, enquanto por Nikolai e Serguei acredita ter cultivado um sentimento de amor especial, além de respeito e admiração.

Em 1851, na época em que morou no Cáucaso, Tolstói descreveria uma experiência onírica: "Hoje, 22 de dezembro, eu acordei de um sonho terrível - o cadáver de Mítinka. Trata-se de um desses sonhos que não se esquecem. Isso pode significar algo? Eu chorei muito." ${ }^{44}$ De novo, em suas Reminiscências, Tolstói relata admirar seu irmão Dmítri dado a seu fervor religioso e, sobretudo, por sua indiferença a respeito do que outras pessoas pensavam dele, o que também era uma característica de Nikolai. Uma vez inebriado pelos efeitos de sua "conversão", embora afogado em remorsos, Tolstói revela: "Como é claro para mim agora que a morte de Mítinka não o aniquilou, que ele existiu antes que eu o conhecesse, antes até que ele tivesse nascido, e que ele existe agora, depois de ter morrido" ${ }^{45}$. Dmítri morreria de tuberculose em 21 de janeiro de 1856. Em oposição ao socorro que prestaria a Nikolai no momento de sua morte, Tolstói permaneceria apenas um dia em Oriol, onde Dmítri sucumbiria. Os maus pensamentos que nutrira por ele, de súbito, o autor diz, naquela ocasião, desvaneceramse. Sentindo-se terrível, Tolstói julga nada poder fazer.

Quatro anos depois do falecimento de Dmítri, com o qual Tolstói se envolveria o mínimo possível, morreria Nikolai, também de tuberculose, em 20 de setembro de 1860. Como enfatiza McLean (2008), Nikolai era o irmão amado e admirado, um modelo cultuado nos anos de infância, um companheiro durante as aventuras no Cáucaso, um consultor literário $^{46}$, um homem isento de vaidades. Desse evento de morte Tolstói não se eclipsaria, até porque já se sentia em débito pela forma como se comportara por ocasião da morte de Dmítri. Ele se manteve em vigília, cheio de fé, à cabeceira da cama do irmão moribundo até testemunhar seu derradeiro suspiro. Nikolai morreria em seus braços. Em carta a Serguei, em outubro de 1860, ele diria:

\footnotetext{
${ }^{43}$ Воспоминание

${ }^{44}$ TOLSTÓl apud MCLEAN. Hugh. In Quest of Tolstoy. Tradução minha. Brighton: Academic Studies Press, 2008. p. 38

${ }^{45}$ MCLEAN. Hugh. Op. cit. p. 38

${ }^{46}$ Segundo Hugh McLean, além de escrever, Nikolai dava conselhos literários a Tolstói.
} 
Você já deve ter recebido a notícia da morte de Nikólenka. Eu estou triste por você não ter ficado aqui. Não importa o quão doloroso seja isso, eu estou bem por tudo ter acontecido na minha presença e por que os efeitos em mim se deram tal como eu esperava. Não foi como a morte de Mítinka, que eu fiquei sabendo em Petersburgo quando não estava pensando nele. Foi algo completamente diferente. No caso de Mítinka, eu estava cerceado por memórias e laços familiares, enquanto no caso de Nikólenka estamos falando de um homem de verdade para você e para mim, alguém que amamos e respeitamos mais do que ninguém na terra. ${ }^{47}$

Já nessa carta, Tolstói expressa certo remorso por não ter estado presente à morte de Dmítri, justificando-se com o fato de que ele não teria morrido em boa hora - ou que não era suficientemente importante, se comparado a Nikolai. No entanto, podemos sugerir que, pela personalidade radical e introspectiva, Dmítri talvez tenha conseguido alcançar tudo aquilo que Tolstói tanto almejara em sua vida e, sobretudo, no fim de seus dias: a sobriedade religiosa. Para compensar seu descaso diante da morte de Dmítri, porém, Tolstói compõe o personagem Nikolai Liévin do romance Anna Kariênina, irmão preferido e mais afinado a Liévin, em oposição a Kóznichev. Contrariamente ao que possa parecer, Nikolai Liévin não fora inspirado em Nikólenka, mas em Dmítri Tolstói. Para atenuar sua omissão, Tolstói concede a Dmítri a partida que ele deveria ter tido: ao lado da família. Dessa vez, estão todos ao redor de sua cama para confortá-lo: Liévin, Kitty, Agáfia Mikháilovna, o médico, o padre. Munido da coragem que lhe faltara alguns anos antes, Tolstói proporcionava, na ficção, o calor humano que o solitário Dmítri não tivera na vida real. Dmítri morria de novo, só que dessa vez sob os cuidados que, em diferentes condições, foram dispensados apenas a Nikolai Tolstói ${ }^{48}$. Era preciso dar-lhe uma boa morte, conceder-lhe a dignidade que Tolstói supunha ser primordial aos "irmãos formigas". A morte de Dmítri, pela dilacerante culpa que gerou em Tolstói (propiciando uma expiação literária ${ }^{49}$ ), uma vez que o autor jamais se aproximara do irmão além das fronteiras da ficção, talvez o tenha afligido

\footnotetext{
${ }^{47}$ Ibidem. p. 48

${ }^{48}$ Essa passagem, sem dúvida, por todas as variáveis que compreende, é das mais belas da literatura mundial e, por isso, não poderíamos deixar de citar as conexões entre vida e obra como forma de promover um maior entendimento.

${ }^{49}$ Reparação (Atonement), romance celebrado e contemporâneo (2001) do escritor britânico lan McEwan, que, por sua vez, inspirou o filme homônimo de 2007, traz à baila essa idéia de "expiação literária" a que Tolstói alude em Anna Kariênina. Seria interessante, nessa chave, investigar que outros escritores (além da ficcional "Briony Tallis") usaram do mesmo artifício literário como forma de livrar-se de uma culpa (relativa à morte) concernente a suas biografias.
} 
psicologicamente na mesma proporção da morte de Nikolai, em 1860. Ele não se perdoaria pela negligência, a ponto de apresentar, durante a velhice, delírios com o irmão.

Em 23 de agosto de 1904, morre, aos setenta e oito anos, o irmão mais velho de Tolstói: Serguei. Um câncer na língua o torturara por anos. Tolstói diria que Serguei fora seu irmão amado e incompreendido, muito embora lhe houvesse sido negado um genuíno contato com a fé. $\mathrm{Na}$ época, o semblante de Tolstói já sinalizava tensa melancolia por causa da morte de sua querida prima Aleksandrine Tolstói, com quem estabelecera uma relação de ternura, cumplicidade e autêntica amizade por mais de meio século. Ela morrera em 21 de março de 1904, aos 86 anos. Seu passado se deteriorava no compasso do tempo - imune à restauração.

Pouco mais de 40 anos antes, em 1862, seguindo o curso natural da vida, ele se casara. A reboque da sensação de orfandade que sempre o movera, ávido por encontrar sua amada e constituir sua própria família, seu "formigueiro", ele não poderia prever que tantas mortes dolorosas turvariam seu caminho.

Dos treze filhos que Tolstói tem com Sofia Andréievna, seis falecem enquanto ele está vivo. Em 1873, Piotr, de 15 meses, sucumbe à difteria. "Isso é novo para mim e muito doloroso, especialmente para Sónia" ${ }^{50}$ - relata em uma carta ao irmão Serguei, ainda que, na mesma missiva, não deixe de comentar acertos técnicos para um romance em gestação. Seguidamente a Piotr, no início de 1875, o seu sétimo filho, Nikolai, de apenas nove meses, tem a vida abreviada por uma galopante meningite. $\mathrm{O}$ ano é implacável para o casal Sónia e Liev, que não resistem a uma atroz depressão. Segundo Sónia, Tolstói estava tomado por uma espécie de morte emocional e, por anos a fio, não pôde se concentrar em coisa alguma. Para incrementar o opaco panorama, em outubro de 1875 , Sónia dá à luz uma menina prematuramente, que morre tão logo nasce.

Por pouco mais de dez anos, o casal não seria afetado por esse tipo de infortúnio, até que o pequeno Aleksiei, de quatro anos e meio, morreria em 1886. Outra década se encerraria se, em decorrência da escarlatina, Ivan, nascido em 1888, não falecesse em 1895. A moléstia de Ivan o consumiria rápido, e o que a princípio fora diagnosticado como uma simples gripe, levou-o à morte cerca de um mês e meio após os primeiros sintomas. A perda devastaria por completo o espírito de Sónia, que jamais se recuperaria. Já Tolstói, intoxicado pela sua "conversão", vê a morte do filho como uma

\footnotetext{
${ }^{50}$ TOLSTÓl apud SHIRER, William. Amor e Ódio. São Paulo: Paz e Terra, 1997. p. 92
} 
manifestação de Deus, "puxando-me em sua direção". ${ }^{51}$ Tratava-se, para ele, de um fato misericordioso que, feito uma dádiva vinda dos céus, desenredaria as mentiras da vida. "Sónia não consegue ver desse modo. Para ela, a dor - quase física - da separação esconde a importância espiritual do fato" ${ }^{52}$. Temos a impressão aqui de que Tolstói reluta em perceber que, ao desvalorizar a dor de uma mãe que perde um filho de sete anos, ele não está pondo lenha na fogueira da fé, mas fechando os olhos para o outro que, como vamos examinar, de acordo com seus próprios escritos "pós-conversão", seria o único meio de chegar a Deus e de esquivar-se da morte. Suas palavras, porém, podem ser atribuídas à dificuldade de lidar com a dor ocasionada pela perda do querido filho - o que justifica, em parte, sua estranha reação.

Por fim, em 1904, morreria de pneumonia, aos 35 anos, sua filha preferida e melhor amiga, Maria. Na ocasião, Tolstói, que acompanhou as etapas do óbito da filha, registra não ter sofrido tanto. Ela teria morrido de forma calma e, segundo ele, "ela era uma criatura experimentando uma revelação" 53 - o que o deixou contente.

Todas essas perdas familiares, entre muitas outras de pessoas menos próximas, foram eventos perturbadores e emocionalmente desgastantes para Tolstói. A necessidade de entendê-las à luz da razão, que se intensificaria com a maturidade, conduziria o escritor a um plano paralelo traduzido pelo movimento de fé.

\subsection{Uma personalidade em conflito}

Ao lado da presença da morte na biografia de Tolstói, caminhava também uma personalidade angustiada, dualista, que precisaria ser examinada como precedente de seu foco na morte - isto é, sua busca de um sentido na vida que a morte não teria o poder de destruir. Esse caráter vai dar ensejo à urgente "questão" do autor, declarada de maneira "sonora" em Uma confissão, muito embora pistas nesse viés possam ser rastreadas em trabalhos mais antigos.

Alguns autores levam-nos a crer que a obra do escritor pode ser compreendida, assim, em duas fases bastante distintas, o que não é de todo verdade. Em Tolstoy: an approach, Janko Lavrin (1946) observa que jamais se deu uma ruptura repentina em sua

\footnotetext{
51 Ibidem. p. 199

52 Ibidem. p. 200

53 Ibidem. p. 276
} 
carreira que pudesse marcar um nítido divisor de águas. O artista, em hipótese nenhuma, estava sendo destronado para a coroação de um impetuoso teólogo. Ao longo da vida do autor, os mais variados trechos demonstram que o conflito entre o Tolstói artista e o Tolstói moralista, que explorava o sentido da vida (à procura de um elemento que burlasse a morte), é a tônica. Sobre essas supostas fases, Lavrin comenta:

O que aconteceu foi apenas uma mudança de proporção entre elas, ou antes um tipo de substituição de um centro de gravidade por outro - um processo que, longe de eliminar o conflito interno de Tolstói, na realidade, intensificou- $0 .{ }^{54}$

No compasso de Lavrin, no ensaio Tolstói ou Dostoiévski, George Steiner (2006) registra que, a despeito da ênfase colocada pelo próprio Tolstói ao condenar sua literatura "no inverno de 1879-1880"55 56, ilustrando um ponto de transição radical, é possível detectar, em grau maior ou menor, em seus escritos precoces, tanto as suas idéias e crenças quanto elementos de sua moralidade. "O moralista e o poeta coexistem em proximidade angustiada e criativa" - aponta Steiner. "No decorrer de sua carreira, o impulso religioso e o artístico lutaram pela supremacia”. ${ }^{57} \mathrm{G}$. W. Spence complementa a assertiva, ao dizer que "As idéias que ele carregou em seu período inicial, em alguma extensão determinou a natureza daquelas apresentadas tardiamente após a chamada conversão" ${ }^{58}$. Boris Schnaiderman acrescenta à discussão a observação de que o doutrinador está presente nas obras tidas como propriamente literárias, mas alerta para o fato de que essa presença é discreta, "o suficiente para não prejudicar a realização". 59

O historiador russo Dmítri Petrovitch Sviatopolk-Mírski salienta que, ao atrelar a Razão ao Bem, designando-a como um valor supremo, "daquilo que ele considera ser a consciência a única e verdadeira porta-voz", Tolstói "coloca seu novo "apetite" em nível de igualdade com o Absoluto, - o "apetite" conhecido pela moral teológica como

\footnotetext{
${ }^{54}$ LAVRIN, Janko. Tolstoy, an approach. Tradução minha. New York: The Macmillian Company, 1946. p. 50

${ }^{55}$ STEINER, George. Tolstói ou Dostóiévski. São Paulo: Perspectiva, 2006. p. 179

${ }^{56}$ A obra Uma confissão (Исповедь) foi escrita por Tolstói nesse período.

57 Ibidem. p. 179

${ }^{58}$ SPENCE, G. W. Tolstoy's Dualism. Tradução minha. Russian Review, Vol. 20, No. 3. Blackwell Publishing, 1971. Disponível em: <http://www.jstor.org/stable/126400>. Acesso: 29/06/2011. p. 217

${ }^{59}$ SCHNAIDERMAN, Boris. Leão Tolstói - Antiarte e Rebeldia. São Paulo: Brasiliense, 1983. p. 26
} 
orgulho espiritual". ${ }^{60}$ Tolstói não tolera mistérios, quer substituir Deus por ele próprio e, por ser dotado de razão, considera essa hipótese perfeitamente realizável. Segundo Mírski, foi essa idolatria de Tolstói pela razão que, em parte, culminou em obras como Uma confissão e $A$ morte de Iván Ilitch; enquanto a vitória da vida sobre a razão (ou sobre a morte) pode ser contemplada, em sua espontaneidade vital, em Guerra e Paz. A morte, com efeito, estaria no fim (ou no começo) de um excessivo, e até patológico, movimento racional. Sua obsessão pela razão alimentava sua obsessão pela morte, e vice-versa.

Lavrin entende que a vida pregressa de Tolstói, repleta de imoralidades, fornecelhe abundante material para que ele se farte em uma posterior regeneração, obtendo daí um prazer espiritual. Esse desejo de auto-perfeição, portanto, cujas etapas lhe concediam enorme satisfação, seria também um estímulo moral que iria envolver sua existência. Quantos mais pecados Tolstói possuísse, mais razões ele teria para rejubilarse por meio de seus planos e regras de retidão moral e abnegação. Regras que se amontoavam na medida em que ele se sentia aviltado por suas paixões (e estas também estariam vinculadas à morte, especialmente em sua obra) e por impulsos obscuros. Nesse sentido, Lavrin comenta:

As regras adotadas por ele devem ter uma validade universal se são para serem válidas sob qualquer condição, e seu dever é endossá-las para o benefício do mundo. $O$ que é bom para sua salvação pessoal, deve ser bom para a salvação de $\operatorname{todos}^{61}$.

Os melhores momentos do Tolstói artista vêm à tona quando ele se entrega sem culpas ao jorro vital que lhe irrompe da carne, sem dar ouvidos ao moralista que nele habita e a suas regras sobre o que é certo ou errado, privando-se de viver ao bel prazer da mera existência. É quando ele canaliza toda sua energia para criação. Ao que parece, porém, Tolstói precisava exercer pleno controle sobre si mesmo, derrubando aquilo que lhe era tão evidente: sua força instintiva. Lavrin (1946) aponta que a conversão de Tolstói resultou numa série de supressões que mutilaram não só sua existência, mas a vida como um todo. "O ascetismo desesperado de Tolstói, longe de erradicar sua sede

\footnotetext{
${ }^{60}$ MIRSKY, D. S. Tolstoy. Tradução minha. The Slavonic and East European Review, Vol. 7. no 19. Modern Humanities Research Association, 1928. Disponível em: <http://www.jstor.org/stable/4202241>. Acesso: 29/06/2011. p. 79

${ }^{61}$ LAVRIN, Janko. Op cit. p. 53
} 


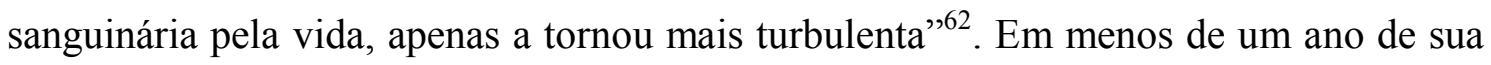
conversão, por exemplo, Tolstói escreveria uma carta ao poeta Afanássi Afanássievitch Fet, na qual conta que, apesar de estar lutando, a beleza da natureza, naquele verão, o conquistara. $\mathrm{O}$ conflito a que Tolstói chegara em nome da razão asfixiava-lhe a vida, a qual não podia já desfrutar. A contradição, nesse caso, residiria no fato de que ele encontraria um sentido para a vida, ou uma "razão para a vida", negando-a.

Tolstói deixou claro em seus escritos, e personagens como Várienka de Anna Kariênina ou fragmentos como Uma confissão são a síntese desse pensamento, que para ser salvo, livrando-se dos tormentos peculiares ao par razão/emoção, o ser humano deve esquecer-se de si mesmo e inflar-se de amor pelo próximo. Lavrin (1946) atenta para o outro lado da questão, ou o lado utilitarista dessa declaração, que não é salvar o próximo, fazer o bem pelo bem e muito menos praticar o amor desinteressado, mas buscar um "egoísta conforto interno" 63 . Tolstói não mede as palavras, ao confessar que toda essa abnegação tem como maior e melhor resultado a "salvaguarda contra o demônio da morte" ${ }^{, 64}$. Ou seja, a contradição residiria no âmago da doutrina de Tolstói, uma vez que, ao sair de si mesmo por meio do amor direcionado ao outro, ele estaria, na verdade, francamente interessado em fugir da angústia da morte - e quanto maior essa, maior sua necessidade de escapar de si mesmo. O grande incentivo para a prática do bem comum repousaria no interesse pessoal de obter o próprio "bem", arrefecendo os desprazeres da realidade da morte.

Em $O$ que eu acredito, ele declara francamente que se deve viver pelos outros, e apenas pelos outros, por causa do imediato benefício pessoal derivado desse amor impessoal. ${ }^{65} 66$

Aqui, além do conflito inato à personalidade de Tolstói, podemos observar o que diz Blanchot, isto é, que o escritor é a partir de sua morte. O medo da morte, a necessidade de afugentar os malefícios que ela carrega como grilhões, a exemplo da descontinuação da vida, da sensação de absurdo ou do cessar da felicidade, seriam assim racionalmente extirpados pela prática do bem. Eis a lógica: se não nos preocupamos com nós mesmos, morremos bem. O temor da morte encerraria um

\footnotetext{
62 Ibidem. p. 65

63 Ibidem. p. 89

64 Ibidem. p. 89

65 Ibidem. p. 89

${ }^{66}$ Grifos meus.
} 
excessivo "amor" por si mesmo - uma egolatria profunda. Tolstói também supunha que a felicidade concedida aos outros não soçobraria com a morte, mas permaneceria intacta no fluxo constante da eternidade. Vemos novamente ecoar a idéia de legado a que Blanchot faz menção. Contraditórias ou não, as idéias de Tolstói, sob esse prisma, são alavancadas pela morte.

\subsubsection{Outra abordagem}

Robert Gustafson (1986), que faz uma leitura notadamente teológica da vida e obra de Tolstói, em vez de falar de artista e moralista, ou irracional e racional, divide a personalidade do autor entre o que ele chama de Residente e Estrangeiro. Sob a perspectiva do Residente, Tolstói seria aquela formiga que, amontoada com as outras, vive o amor em sua plenitude. Nessa existência, ele pertenceria a um mundo onde tudo, como uma música, estaria em perfeita harmonia, sem sugerir nenhuma dissonância. "O Residente pertence quando ele ama" ${ }^{, 67}$. Este Residente, contudo, só pode prevalecer, se a vontade do autor estiver vertida em direção ao outro. O pertencimento só se efetiva por meio da participação na vida dos outros com o trabalho pelo bem comum. Desse modo, Tolstói atinge um estado extasiante de amor por todos. Em 1907, ele elucidaria: "Eu estou sentindo vividamente... a alegria, a calma e o êxtase desse estado de amor por todos. Apenas nesse estado é tudo na vida e na morte bom." ${ }^{68}$ Essa experiência clama pelo pertencimento, pela comunhão da vida com Deus, e a sensação da queda "morro abaixo" em direção à morte desaparece. Tolstói acredita que o maior desejo do homem é ser amado e, nesse âmbito, deve haver reciprocidade, ou seja, ele também deve amar. Para o Residente, o amor é mútuo, recíproco e comunal. A sensação de pertencimento está vinculada à família. Voltaremos a esse ponto, quando examinarmos a presença da morte na obra do autor.

O Estrangeiro, por outro lado, vem à tona quando Tolstói sente na pele a orfandade que o vitimou ainda menino, caracterizada, sobretudo, pela perda da mãe. "O senso da residência familiar é perdido" ${ }^{69}$. A precoce perda dos pais desperta em Tolstói o desejo de estar com seus entes queridos e, nessa trilha, só a morte pode aplacar tal

\footnotetext{
${ }^{67}$ GUSTAFSON, Richard F. Op. cit. p. 9

68 Ibidem. p. 10

${ }^{69}$ Ibidem. p. 13
} 
sofrimento, tal desejo não realizado. O modelo de Deus de Tolstói é justamente a mãe que jamais conheceu. Sem poder, assim, gozar da sensação de pertencimento, Tolstói é Estrangeiro. Ele destrói relações, torna a vida com a esposa um inferno, despreza o meio do qual faz parte, rejeita suas obras-primas e tem dificuldade de amar ou de confiar nos outros. Além disso - assinala Gustafson (1986) -, ele é inflexível, não consegue tolerar oposições às suas opiniões. Só compartilha de sua vida com seu diário, o qual, ao fim, só Tchertkov, um seguidor fanático, teria permissão de ler. Em vez de focar a vida nos outros, o Estrangeiro foca-a em si mesmo, sendo o extremo oposto do Residente. Enquanto este aceita, aquele rejeita. Em lugar de viver a vida, o Estrangeiro observa-a, sendo um espectador que mantém diários. Por fim, o Estrangeiro não encontra um propósito em sua vida e sente a morte devorá-lo a cada minuto, ao passo que o Residente não teme a morte e acredita que sua vida faz parte da eternidade simbolizada por Deus. Em Uma confissão, bem como na vida do autor, Residente e Estrangeiro se alternam, até que, na hora da decisão, o Residente, até onde sabemos, prevalece.

\subsubsection{Memórias}

Nas memórias que marcaram o início da carreira de Tolstói, Infância, Adolescência e Juventude, a face moralista do autor pode ser identificada em várias passagens. Quando ele descreve sua tristeza pela morte da mãe, por exemplo, o espectador de si mesmo - do qual falamos - se pronuncia:

Antes e depois do sepultamento, eu chorei sem parar e estive triste, porém dá-me vergonha recordar essa tristeza, porque a ela sempre se mesclava um que outro sentimento tocado do meu amorpróprio: ora o desejo de mostrar que eu estava mais desconsolado do que todos, ora a preocupação com o efeito que eu produzia sobre os outros, ora a curiosidade à-toa que me fazia observar a coifa de Mimi e os rostos dos presentes. Eu desprezava-me por não experimentar exclusivamente o sentimento de amargura e esforçava-me por ocultar todos os outros; isso tornava a minha tristeza insincera e artificial. Para além do mais, eu experimentava um certo deleite em saber que era infeliz, esforçava-me 
por excitar a consciência da minha desdita, e esse sentimento egoísta, mais do que os outros, abafava a verdadeira tristeza em mim. ${ }^{70}$

Aqui, além do menino carente - que irá redundar em um homem à cata da possibilidade da morte -, que se deixa envolver pelo sentimento de orfandade e está ávido para chamar atenção após perder a pessoa mais importante de sua vida, implorando, nesse rastro, pela piedade e reconhecimento alheios, vemos alguém que medita. "Sem saber se seu sofrimento é sincero e temendo que possa ser apenas um show de vaidade" ${ }^{71}$, o que lhe causaria horror, Tolstói é aquele que vive e aquele que observa aquele que vive de um lugar remoto, exibindo a frieza e o cálculo, sem se abalar um milímetro diante de pareceres secos - estranhos pela sinceridade exibida -, que ora condenam, ora apreciam comportamentos a ele atribuídos por si próprio.

Não importa o quão profundas e espontâneas fossem suas emoções, a fria lâmina da análise estava lá, pronta para observar, dissecar, e muito freqüentemente também para condenar. $O$ resultado óbvio de tal hábito foi uma crescente consciência (...) do que "não é certo". ${ }^{72}$

No capítulo XIX de Adolescência, Tolstói revela o conteúdo da maioria de suas divagações quando garoto, o que a um iniciado na obra e pensamento do autor não suscita tanta surpresa. Já naquele período, ele reconhece o sentido de moralidade que lhe serve como combustível, e reflete sobre temas como o destino do homem, o futuro e a imortalidade da alma, referindo-se a essas questões como as de maior qualidade sobre as quais o intelecto tende a se ocupar.

Alguns pensamentos, de tão evidentes, incitam-no a uma aplicação real, uma vez que ele acredita estar de posse de "verdades inestimáveis", ". Para provar, por exemplo, que o poder da mente pode tolerar qualquer dor física, ele segura um bojudo dicionário da largura do braço por cinco minutos, ou vai ao depósito e chicoteia suas costas até verter lágrimas involuntárias. Há, nesses casos, sem dúvida, um desejo deliberado de enaltecer a força de sua consciência, o poder da razão, mas, de outra forma, há um

\footnotetext{
70 TOLSTÓI, Lev. Infância. Tradução do russo: Noé Silva. No prelo, 2012.

${ }^{71}$ GUSTAFSON, Richard F. Op. cit. p. 31

72 LAVRIN, Janko. Op. cit. p. 51

${ }^{73}$ TOLSTOY, Lev. Boyhood. Tradução minha. Tradução do russo: C.J. Hogarth. Disponível em: <http://www.gutenberg.org/files/2450/2450-h/2450-h.htm>. Acesso: 14/07/2011.
} 
estado de extremo prazer advindo da sensação de sofrimento, semelhante àquele que atormenta o escritor quando ele relata a morte da mãe ou trata de sua relação com o pecado, o que revela, sob certa ótica, uma tendência ao masoquismo ${ }^{74}$.

De outra vez, o adolescente constata que a morte pode acometê-lo a qualquer instante e, sem encontrar um motivo para fazer o que quer que seja, ele deixa os estudos de lado e, estirado na cama por dois ou três dias, lê romances e come apenas pães de gengibre ${ }^{75}$ com mel. Nesse rastro, ao mirar um cavalo pela janela, ele interroga-se: "Em que animal ou ser humano o espírito desse cavalo irá se transformar com a morte?" Em seguida, contudo, julga a pergunta absurda.

Tolstói se diz movido pelo ceticismo e acredita que ninguém exista no mundo exceto ele. De todo esse esgotamento mental, porém, Tolstói supõe ter herdado, dentre outras coisas, o hábito da análise moral perpétua. Afirma ser dotado de um excesso de razão. Por isso, cada descoberta filosófica feita deixa-o tão orgulhoso que ele se imagina "um grande homem descobrindo verdades em benefício da humanidade"77. Tal era a mente desse futuro "servo de Deus" ainda antes de completar 20 anos.

\subsubsection{Diários de juventude}

Boa parte das regras que Tolstói desenvolve está em seus diários de juventude. São inúmeras, versam sobre todo e qualquer assunto, e a disposição para escrevê-las é muito maior quando comparada à disposição para colocá-las em prática. No dia 17 de junho de 1850, por exemplo, com apenas 21 anos, ele escreve:

Segundo dia de preguiça. Não cumpro o que foi traçado. Por quê? Não entendo. Porém, não me desespero, vou forçar-me. Ontem, além de não ter cumprido o determinado, ainda infringi a minha regra. Agora, já não infringirei a regra de, na aldeia, não ter nenhuma mulher, exceto em

\footnotetext{
${ }^{74}$ Questões dessa ordem são analisadas por Daniel Rancour-Laferriere em Tolstoy on the Couch: Misogyny, Masochism, and the Absent Mother, publicado em 1998 pela NYU Press.

75 Пряник. O pão de gengibre, ou pão de especiarias - já que leva uma série de ingredientes além do gengibre (имбирь) - é muito popular na região de Tula, onde existe, inclusive, o Museu do Pão de Gengibre (Музей Тульский Пряник). Receitas: <http://www.gotovim.ru/recepts/bake/pryaniky/>. Mais informações: <http://www.gotula.ru/tula/29.htm>.

${ }^{76}$ Ibidem.

77 Ibidem.
} 
algumas ocasiões que não buscarei, mas que também não deixarei passar. $(. . .)^{78}$

Em 1851, aos 22 anos, ele revela em seu diário algo da disposição mórbida de espírito que dele se apoderaria anos depois: “(...) há algo especialmente grande e grandioso na indiferença à vida e eu me deleito com esse sentimento. Quão forte eu me pareço contra tudo, com a firme convicção de que aqui não há nada por que esperar, além da morte"79. Por encontrar, mesmo que irracionalmente, a possibilidade da morte, Tolstói se sente poderoso. Poderoso e forte porque livre. Ao aceitar a morte sem desespero, ele se liberta dela e pode criar sem a sua intromissão.

Em cinco de fevereiro de 1852, já aos 23 anos, ele continua dizendo-se indiferente à vida, uma vez que a felicidade é pouca para amá-la. E prossegue, revelando a contradição e a dualidade presentes em sua consciência. Na primeira frase, ele é livre. Na segunda, prisioneiro: "Não temo à morte e também não temo os sofrimentos. Mas temo não poder suportar nem os sofrimentos nem a morte." ${ }^{, 80}$ Em 20 de março do mesmo ano, o jovem Tolstói constata: "É preciso confessar que uma das mais importantes ambições da minha vida era convencer-me de algo de maneira firme e constante 81 - Que certeza é tão firme e constante quanto a certeza da morte? A anotação de Tolstói, contudo, parece ser o prelúdio daquilo que ele escreveria em Uma confissão, quando diz ansiar por algo na vida cujo sentido a morte não devore. E indaga: "Será que com os anos as dúvidas crescem?" 82 . Suas dúvidas não só iriam crescer como solucioná-las tornar-se-ia o propósito de sua existência. No mesmo ano, só que em 29 de junho, o jovem Tolstói recorre à razão, que chama de "clareza", para resolver o conflito que no momento o absorve: a questão da eternidade da alma, da imortalidade. A “clareza" para ele é o árbitro soberano.

(...) a minha inteligência se nega a compreender a eternidade. Alguém disse que o indício da verdade é a clareza. Embora seja possível

\footnotetext{
${ }^{78}$ QUINTERO N. C. E. Os diários de juventude de Liev Tolstói, tradução e questões sobre o gênero de diário. 2010. 155 f. Dissertação (Mestrado) - Faculdade de Filosofia Letras e Ciências Humanas, Universidade de São Paulo, 2010. p. 45

${ }^{79}$ Ibidem. p. 85

${ }^{80}$ Ibidem. p. 85

81 Ibidem. p. 86

82 Ibidem. p. 86
} 
discutir isso, a clareza permanece como o melhor signo e é sempre necessário verificar seus juízos por meio dela. ${ }^{83}$

A morte incita a razão de Tolstói, uma vez que nada lhe soa transparente neste nebuloso terreno. Em 17 de novembro, em seu movimento racional oscilante, o jovem escritor se sente Estrangeiro, percebendo como inevitável seu afastamento do mundo: "Devo acostumar-me a que ninguém nunca me entenderá. Esse destino, talvez comum a todas as pessoas, é muito penoso." ${ }^{\text {} 4}$ No dia 31 de outubro de 1853, no entanto, Tolstói se mostra insatisfeito com o instrumento que tem nas mãos para lidar com as paixões, talvez prevendo um futuro trágico a tal refrega - ou antevendo a falibilidade da razão, que traria à baila seus limites: "E a razão, ao agir irregularmente, é fraca contra as paixões" ${ }^{\prime 85}$. Ao final, diz não suportar nem a felicidade, que o estragou com mimos, nem a infelicidade. Esse conflito de personalidade se estenderia e se intensificaria com os anos, redundando na fase pós-conversão.

\subsection{Uma confissão}

Uma confissão, sob certa perspectiva, é uma autobiografia, em que todos os elementos gravitam ao redor da morte. A conversão de Tolstói, em última análise, davase como um meio de fugir das aflições geradas pela consciência do evento da morte. Uma forma definitiva de encontrar uma possibilidade para aquele câncer que o paralisava. "Trata-se do primeiro trabalho escrito durante seu intenso estudo dos Evangelhos" ${ }^{\text {"86 }}$, situando-se entre Guerra e Paz e Anna Kariênina e seu retorno à ficção com $A$ morte de Iván Ilitch e $O$ Poder das Trevas. O texto se desenvolve, contudo, como uma descrição da trajetória de sua fé e de sua relação com Deus que, por fim, será um sinônimo ou um epíteto para a palavra amor. David Patterson assinala que esse movimento de fé surge como o quarto aspecto de uma metamorfose de quatro dimensões: “(1) o encontro com a morte, (2) o acesso de desespero, (3) a luta pela

\footnotetext{
${ }^{83}$ Ibidem. p. 104

${ }^{84}$ Ibidem. p. 114

${ }^{85}$ Ibidem. p. 128

${ }^{86}$ FLEW, Antony. Tolstoi and The Meaning of Life. Tradução minha. Ethics, Vol. 73 no 2. The University of Chicago, 1963. Disponível em: <http://www.jstor.org/stable/2379552>. Acesso: 13/06/2011. p. 110
} 
possibilidade, e (4) o movimento de fé" ${ }^{87}$. No esquema é o encontro com a morte que desencadeia o processo. Gustafson complementa: "Somente na morte Tolstói encontraria sua verdadeira e completa natureza." 88

A crise, recrudescida pelo tempo entre o Tolstói moralista e o Tolstói artista, chega ao paroxismo, e não lhe resta outra alternativa a não ser abraçar a fé, pelo menos em teoria, engessado pelo pavor que a morte lhe incita mediante uma verve racional que o aturde desde a infância. $\mathrm{O}$ escritor, mais do que nunca, era talhado a partir da morte, vendo sua possibilidade apenas em uma existência devotada ao próximo. Encontrar um sentido para vida torna-se necessário porque, em todo o caso, há a alternativa de morrer, de desistir da vida, sempre a seu encalço. É essa (im)possibilidade, ou essa oposição à vida apresentada como escolha, que o leva a questionar o valor da existência em face de todos os seus sofrimentos ou alegrias, uma vez que, como enfatiza o próprio Tolstói em Uma confissão, para dar um fim a essa piada estúpida bastaria "uma corda em torno do pescoço, água, uma faca para cravar no coração ou os trens nas ferrovias" 89.

\subsubsection{Gatilhos iniciais}

Tolstói acomoda-se, desse modo, em um confessionário onde todos nós, seus leitores, temos a oportunidade de absolvê-lo ou condená-lo. Inicia seu percurso pela fé advinda do Cristianismo Ortodoxo. Embora tenha sido batizado e criado nessa fé, ele diz que aos dezoito anos já não acreditava em mais nada do que havia aprendido. Tolstói entende que, na maioria dos casos, a religião, pelo menos a Ortodoxa, e a vida, são coisas que não andam juntas, sendo levadas adiante independentemente, e reconhece que seu desligamento da religião se deveu a tal incongruência.

(...) a doutrina religiosa não faz parte da vida, tanto na interação com outras pessoas quanto na vida privada; essa doutrina religiosa é pregada lá longe, em algum lugar distante da vida e dissociado dela.

\footnotetext{
${ }^{87}$ PATTERSON, David. The Movement of Faith as Revealed in Tolstoi's “Confession”. Tradução minha. The Harvard Theological Review, Vol. 71 no 3/4. Harvard Divinity School, 1978. Disponível em: <http://www.jstor.org/stable/1509617>. Acesso: 15/07/2011. p. 227.

${ }^{88}$ GUSTAFSON, Richard F. Op. cit. p. 6

${ }^{89}$ TOLSTOY, Lev Nikolayevich. A Confession. Tradução minha. Tradução do russo: Louise Maude e Aylmer Maude. Disponível em: <http://www.ccel.org/ccel/tolstoy/confession.pdf>. Acesso: 15/06/2011. p. 23
} 
Quando depara com ela, é apenas como um fenômeno externo, sem relação direta com a vida. ${ }^{90}$

Tolstói afirma que sua fé estava depositada no auto-aperfeiçoamento, como corroboram as regras de seus Diários de Juventude. O escritor sublinha a imoralidade em que esteve submersa sua vida por 10 anos, durante os quais matou, jogou, explorou e puniu camponeses, mentiu, roubou, enganou pessoas, cometeu adultérios, bebeu em demasia, enfim, como ele mesmo assinala, "não houve crime que eu não tenha cometido" 91 .

No capítulo III do fragmento, Tolstói descreve como sua fé no progresso, ainda antes de casar-se, foi abalada durante uma visita à Europa, quando, em Paris, no dia 25 de março de 1857, ele testemunhou a execução de François Riche, acusado de homicídio, pela guilhotina:

Quando vi a cabeça se soltar do corpo e cair, separadamente, no cesto, compreendi, não pela razão, mas por todo o meu ser, que nenhuma teoria sobre a racionalidade da ordem existente e do progresso poderia justificar tal ato ${ }^{92}$.

Essa morte, somada à morte do irmão Nikolai aos 37 anos - que Tolstói não entendia por que, ainda jovem, havia sofrido tanto em face de um óbito doloroso, ou por que, afinal, tinha de viver para de repente perecer -, foram gatilhos rumo ao despertar religioso, cuja tônica era a busca do sentido da vida. A morte (no caso, duas mortes atrozes ocorridas de maneiras distintas) desbravou-lhe um caminho, uma direção a seguir a partir de então.

A crise existencial de Tolstói repete-se, dessa vez com muito mais força, cerca de quinze anos após seu casamento. As ocupações que anteriormente o desviavam dessa espécie de preocupação, de súbito, não surtem mais nenhum efeito. Sua vida fica em suspense, à deriva, assume um tom de absurdo e, com cada vez mais freqüência, o escritor receia não saber para que servem ou para onde o estariam levando suas ações

\footnotetext{
${ }^{90}$ TOLSTÓI, Liev. Os últimos dias. Tradução do russo: Anastassia Bytsenko, Belkiss J. Rabello, Denise Regina de Sales, Graziela Schneider e Natalia Quintero.. São Paulo: Penguin Companhia das Letras, 2011. p. 22

${ }^{91}$ TOLSTOY, Lev Nikolayevich. A Confession. Tradução minha. Tradução do russo: Louise Maude e Aylmer Maude. Disponível em: <http://www.ccel.org/ccel/tolstoy/confession.pdf>. Acesso: 15/06/2011. p. 5

92 Ibidem. p. 7
} 
cotidianas. Essas questões, supostamente irrelevantes, adquirem com o tempo um vulto colossal, tomando de assalto sua vida. Não por acaso, Tolstói faz uma analogia acerca desse processo insidioso de domínio:

Assim, ocorreu o que acontece com aqueles acometidos por uma doença interna letal. Primeiro, sinais triviais de indisposição aparecem (...); então esses sinais reaparecem com cada vez mais freqüência e se transformam em um ininterrupto período de sofrimento. $O$ sofrimento aumenta (...) e o que ele julgava ser uma mera indisposição se torna para ele mais importante do que qualquer outra coisa no mundo - isso é a morte! $!^{93}$

\subsubsection{O episódio de Arzamáz}

Em sua biografia de Tolstói, Henri Troyat (1967) chama a atenção para uma noite sinistra que o escritor passou em Arzamáz, cidade russa localizada na região de Níjni Nóvgorod $^{94}$, em 1869. Na época, ele estava lendo Schopenhauer apaixonadamente, tendo pendurado um retrato do filósofo em seu escritório - o que, em Uma confissão, iria revelar-se como mais um equívoco. Por ter acabado de entregar Guerra e Paz ao editor, ele mostrava-se, segundo Sónia, "meditativo" 95 . E acrescenta: "Freqüentemente ele dizia que o cérebro estava ferindo-o; algum processo doloroso se passava dentro dele, tudo estava acabado para ele, era hora de ele morrer" ${ }^{96}$. Apesar da vida e da carreira de Tolstói estarem em seu ápice, e de o escritor estar mais saudável e bem disposto do que nunca, ele temia a morte. Segundo Troyat, esse temor se devia, na verdade, ao fato de que não havia absolutamente nada a temer. Tal constatação lhe soava simplesmente aterrorizante.

"No intuito de fortificar suas defesas contra o perigo de vida"97, Tolstói decide comprar mais terras. Alargando seus domínios, aumentando seus bens, perpetuando sua "vida na terra" ao fincar ainda mais raízes nela, ele, por conseguinte, poderia encontrar um refúgio seguro a salvo da morte. Tolstói chegaria, no dia 2 de setembro, de trem a

\footnotetext{
93 Ibidem. p. 9

94 Нижний Новгород

${ }^{95}$ ANDRÉIEVNA apud TROYAT, Henri. Op. cit. p. 317

96 Ibidem. p. 317

${ }^{97}$ TROYAT, Henri. Op. cit. p. 317
} 
Níjni Nóvgorod, lugar no qual iria ter com o vendedor das terras. Como pretendia dar uma espécie de golpe, tirando proveito da negociata, Tolstói estava ansioso e, com saudades de casa, resolveu saltar do trem e pernoitar em Arzamáz. Tudo ali, como em um filme de terror, lhe parecia soturno: o porteiro da pensão com uma mancha na face, o quarto quadrado de paredes vermelho-escuras que alugara, o silêncio insólito da cidade que descansava. Ao se deitar, Tolstói imediatamente adormeceu. Quando se levantou, contudo, no meio da noite, nada mais lhe soava familiar, nem seu propósito anterior de adquirir terras. A escuridão o perseguia na medida em que andava trôpego pelo cômodo, e assustado, prestes a perder o controle, ele pensou: "Isso é ridículo. (...) Por que estou tão deprimido? Do que eu tenho medo?" 98 - ao que ouviu: "De mim respondeu a Morte - Eu estou aqui." ${ }^{99}$ Nesse momento, foi desencadeada uma crise de pânico avassaladora em sua alma, e Tolstói teve a certeza de que a morte, aquele monstro abominável, viera buscá-lo. Encontrou uma vela que, mesmo acesa, não espantou a horrenda criatura. A fim de recobrar o juízo, ele tentou rememorar seus projetos de vida, mas o quarto em que estava lhe pareceu a caixa na qual caía a cabeça de François Riche degolada pela guilhotina e, por fim, um estéril caixão. Não compreendeu como as pessoas podiam dormir ali, com a morte imiscuindo-se entre elas. Rezando em agonia, "imaginou a morte penetrando em cada poro de sua pele, enfraquecendo e apodrecendo seus órgãos, atando sua língua e corroendo seu cérebro" 100 . De rompante, ele pulou da cama e desistiu de tudo. "Não ficaria nem um minuto mais naquela estalagem assombrada, por nenhum dinheiro do mundo" 101. Acabou adormecendo de novo e, no dia seguinte, já estava de posse de suas faculdades normais, ainda que não quisesse mais ficar. Tolstói jamais se esqueceria daquela noite em Arzamáz, na qual o desespero e o medo consumiram-no de maneira sem precedentes. Esse pesadelo o acompanharia pelo resto de seus dias.

\footnotetext{
98 TOLSTÓI apud TROYAT, Henri. Op. cit. p. 319

99 Ibidem. p. 319

100 TROYAT, Henri. Op. cit. p. 319

${ }^{101}$ TOLSTÓl apud TROYAT, Henri. Op. cit. p. 319
} 


\subsubsection{Desespero, suicídio e busca da possibilidade}

No rastro dessa noite aterrorizante, é possível dimensionar por que as questões que assombravam o autor careciam de urgente resolução, sob a pena de que ele sofresse um colapso. Era primordial saber qual o sentido do conjunto de elementos que constituíam a vida, ou não haveria mais uma "razão" para se levantar pela manhã e lutar por tal causa. A existência de Tolstói se torna mecânica, automática, inerte, e lhe sobrevém um desejo de se livrar de tal desesperança, dessa perturbadora ausência de fé. Para ele, não se tratava exatamente de uma vontade de dar cabo da própria vida, mas de "uma força semelhante à minha antiga aspiração pela vida, só que em sentido inverso" $" 102$. Tolstói parece ser vítima do desespero ao qual alude Kierkegaard, uma vez que a morte, ou a sensação de estar morto, intercepta-o em vida. Kierkegaard considera que estar mortalmente doente significa não poder morrer, muito embora a vida se torne inócua: a esperança se esfarela, a vontade se desvanece, e, nesse rastro, "a desesperança é a impossibilidade da última esperança, a impossibilidade de morrer" ${ }^{103}$. Desse modo, a morte se torna uma esperança para o indivíduo acometido pelo desespero, sem, no entanto, poder ser de fato executada. Kierkegaard distingue morrer - a condição em que tudo está acabado -, de morrer a morte, que significa viver a morte. E sublinha: "e vivêla um só instante, é vivê-la eternamente" ${ }^{104}$. A maior tortura desse estado, assim, é a impossibilidade da morte, essa sensação que se desdobra em angústia, torpor, confinamento, visto que, como vimos em Blanchot, a saída está, em contrapartida, na possibilidade da morte, em "morrer contente". De forma bastante semelhante à encontrada por Tolstói, o filósofo dinamarquês contempla essa possibilidade na superação do $e u^{105}$ rumo ao poder que o criou. O poder que o criou, no caso, pode ser identificado como Deus.

Abandonado no cerne desse desespero, Tolstói teme a vida. Ela lhe é odiosa e, para não tomar uma decisão drástica, o escritor evita situações em que possa cometer suicídio, uma idéia que o seduz progressivamente.

\footnotetext{
102 TOLSTOY, Lev Nikolayevich. A Confession. Tradução minha. Tradução do russo: Louise Maude e Aylmer Maude. Disponível em: <http://www.ccel.org/ccel/tolstoy/confession.pdf>. Acesso: 15/06/2011. p. 10

${ }^{103}$ KIERKEGAARD, Sören. O desespero humano. In: Col. Os Pensadores. São Paulo: Victor Civita, 1979. p. 199

104 Ibidem. p. 199

${ }^{105} \mathrm{O}$ "eu", para Kierkegaard, seria uma relação que "não se estabelece com qualquer coisa de alheio a si, mas consigo própria", orientando-se "dessa relação para própria interioridade". Ibidem. p. 195
} 
(...) escondia de mim mesmo a corda para não me enforcar na trave, entre os armários do meu quarto, onde cada tarde ficava sozinho para me despir; não ia mais à caça com meu fuzil para não me deixar tentar por este meio tão fácil de alijar a vida. ${ }^{106}$

Um dos maiores enigmas para Tolstói residia em compreender o motivo pelo qual ele deveria esforçar-se mediante uma vida cujo fim era certo, como se o ocaso fosse retirar-lhe todo o significado conquistado a duras penas no decurso dos anos. A existência, desse modo, descortina-se, aos seus olhos contaminados pela racionalidade, como uma fraude infame. $\mathrm{O}$ escritor afirma que não pode mais viver sem apreender o sentido da vida - embora ele só vislumbre um famigerado dragão esperando-o no fundo de um poço, enquanto o esquálido ramo de galhos ao qual se aferra é roído por dois ratos. Sair do poço de nada adiantaria, já que um animal feroz, do lado de fora, está à sua espreita. As distrações que o afastam desse tenebroso cenário, como o amor da família e a arte, não the parecem mais doces como outrora pareceram. Os homens estariam caminhando para a verdade. "E a verdade é a morte". ${ }^{107}$ A morte iria solapar todo o resto.

$\mathrm{Na}$ trilha de uma solução para tamanho sofrimento, Tolstoi formula a pergunta: "Há algum sentido em minha vida cuja ocorrência inevitável da morte que me espera não vá destruir?" ${ }^{108}$ A ciência, entretanto, o desaponta, já que esta ignora por completo as questões da vida. Segundo Tolstói, se um cientista fosse indagado sobre "o motivo pelo qual vivemos", responderia, sem vacilar: "no espaço e tempo infinitos, pequenas partículas mudam infinitamente suas formas em um processo de infinita complexidade, e quando você tiver entendido as leis dessas mutações de forma, você terá compreendido por que vive na terra" ${ }^{109}$ - o que denota certo escárnio e, na seqüência, aversão à ciência por parte do autor. Essa aversão se desdobraria em um desprezo pelos médicos e seus procedimentos, posto que esses "cientistas-médicos", a despeito de ocuparem-se em manter as pessoas vivas a qualquer custo, desconhecem o significado da vida, quando o mais indicado, em alguns casos, seria deixá-las partir desapegando-se

\footnotetext{
${ }^{106}$ TOLSTOY, Lev Nikolayevich. A Confession. Tradução minha. Tradução do russo: Louise Maude e Aylmer Maude. Disponível em: <http://www.ccel.org/ccel/tolstoy/confession.pdf>. Acesso: 15/06/2011. p. 11

${ }^{107}$ Ibidem. p. 12

108 Ibidem. p. 14

${ }^{109}$ Ibidem. p. 15
} 
da matéria. Às vésperas da morte de sua filha, Maria, em novembro de 1904, Tolstói condenaria em carta para Tchertkov as copiosas tentativas de salvá-la: "Esses esforços vãos para prolongar sua vida através de tratamento médico são eles mesmos lamentáveis e perversos" ${ }^{110}$. Em A morte de Iván Ilitch, as críticas de Tolstói no que tange à medicina também seriam acerbas.

A partir da leitura de alguns filósofos e sábios, Tolstói fundamenta sua tese de que a vida é sem sentido, absurda, inútil e, sobretudo, um mal, o que aumenta seu desespero. Contudo, pensadores como Sócrates, Schopenhauer, Buda ou Salomão, nos quais Tolstói se fia para justificar sua posição, estiveram somente buscando uma vida independente da morte, sem tormentos, na esteira de uma possibilidade para a morte $-\mathrm{e}$ não a temiam, uma vez que, sob esses parâmetros, o viver não estaria mais sujeito ao morrer. Eles não faziam apologia da morte ou refutavam a vida, mas, do contrário, encaravam-na como parte de um processo cuja morte seria um passo evolutivo, uma etapa superior que os libertariam das amarras do corpo, da consciência, das paixões e, nesse rastro, do sofrimento. Sem a vida, e uma vida vivida da melhor forma possível, não se poderia ascender à morte.

Schopenhauer (2004), por exemplo, em Metafísica da morte, reconhece que, com o advento da razão, apareceu, necessariamente entre os homens, "a certeza assustadora da morte"111. Sob esse prisma, o valor objetivo da vida se esfacela, e o "não-ser" acaba por sobrepujar tudo o mais, visto que os poucos anos de vida "desaparecem por completo ante o tempo sem fim no qual não mais se existirá" ${ }^{112}$. O filósofo, contudo, não aposta na racionalidade, mas na vontade de vida que, apesar de cega e irracional, origem de nosso apego à vida e avessa ao conhecimento, é a essência mais íntima do homem $^{113}$. Faceta da eternidade, a vontade de vida está enraizada na espécie, e não no indivíduo. A consciência, assim, seria lapidada na medida em que o ser vivo se afastasse da espécie para constituição do indivíduo no tempo. "Neste encontra-se (...) apenas a

\footnotetext{
${ }^{110}$ TOLSTÓI apud SHIRER, William. Op. cit. p. 275

${ }^{111}$ SCHOPENHAUER, Arthur. Metafísica do amor, Metafísica da morte. São Paulo: Martins Fontes, 2004. p. 63

112 Ibidem. p. 63

${ }^{113}$ Em Metafísica da morte, Schopenhauer nos alerta para a imagem do arco-íris, que permanece colorindo a abóboda celeste enquanto as gotículas de chuva se formam, passam pelo espectro e, em seguida, sucumbem. $\mathrm{O}$ arco-íris seria o infinito e as gotículas, o finito. "Como as gotas pulverizadas da queda d'água estrondosa mudam com rapidez de relâmpago, enquanto o arco-íris, do qual elas são o sustentáculo, está fixo em calma imóvel, (...) assim permanece cada Idéia, isto é, cada espécie de ser vivente pela mudança contínua de seus indivíduos". Ibidem. p. 95
} 
consciência imediata e por isso ele presume ser diverso da espécie" ${ }^{114}$. O temor racional da morte é, então, o temor de apartar-se de mim, da autoconsciência, muito embora "a coisa-em-si", a vontade de vida, seja imortal. Desse modo, o filósofo alemão atribui à razão um papel periférico e superficial, e à vontade de vida, que em nós está imbuída profundamente, um valor eterno, tangenciando uma possibilidade para morte.

Já Sócrates (2005), a despeito de acreditar que a maior aspiração do filósofo é a aniquilação proporcionada pela morte, uma vez que ela determina o momento no qual a alma estará livre do corpo, uma barreira para aquisição de conhecimento, considera o suicídio uma impiedade. Em Fédon, afirma que não é dada ao homem a escolha entre viver ou morrer. Nossas vidas, a bem dizer, pertenceriam aos deuses e apenas estes saberiam o que é melhor para o homem. Platão registra: "talvez não seja absurdo afirmar que ninguém deve partir da vida sem que a divindade envie uma ordem formal" 115 . Pautado na teoria dos contrários, Sócrates argumenta que vida e morte são conceitos entrelaçados, interdependentes, já que cada qual se origina de seu oposto: sem a vida não haveria a morte e vice-versa. Desse raciocínio Sócrates também constrói sua tese sobre a imortalidade. Patterson (1978) ratifica que Tolstói não entende o pensamento de Sócrates, enxergando apenas o que lhe é conveniente: "Quando Sócrates afirma que o sábio passa sua vida se preparando para morte, ele está, na verdade, dando um sentido à vida". 116

Certo, no entanto, de que a filosofia o incentivava a adicionar um termo final à vida, Tolstói considera o suicídio a forma mais honrada de se desfazer dela, e deseja adotá-la. A fraqueza, não obstante, de acordo com suas confissões, o impedem de fazêlo. Sem ação, Tolstói, nessa altura, elenca as quatro formas pelas quais um homem pode se comportar a bordo da existência. A primeira seria não julgando a vida insensata e vivendo-a. A segunda seria viver a vida sem pensar no futuro. A terceira implicaria em entender que a vida é inútil e, em seguida, matar-se. A quarta e última seria, ainda que saiba que a vida é uma grande piada, vivê-la. "Isso era para mim um tormento, era repulsivo. Mas eu permaneci nessa posição" ${ }^{117}$ - alega Tolstói.

\footnotetext{
114 Ibidem. p. 97

${ }^{115}$ PLATÃO. Fédon. São Paulo: Editora Rideel, 2005. p. 22

${ }^{116}$ PATTERSON, David. Op. cit. p. 234

117 TOLSTOY, Lev Nikolayevich. A Confession. Tradução minha. Tradução do russo: Louise Maude e Aylmer Maude. Disponível em: <http://www.ccel.org/ccel/tolstoy/confession.pdf>. Acesso: 15/06/2011. p. 24
} 


\subsubsection{Solução do enigma da morte: união do finito ao infinito}

O escritor chega ao pináculo da reverência à razão, ao dizer que não há nada mais elevado do que esta, atribuindo a ela o título de criadora da vida. Disto, ele conclui que onde há vida, há razão, mas o fato de o raciocínio rejeitar a vida deixa-o confuso. Como, afinal, aquilo que é tão essencial à vida pode condená-la? Tolstói aqui, na verdade, não concebe uma vida não consciente de sê-la. Isso é demonstrado, por exemplo, em Anna Kariênina, quando a cadela de Liévin, Laska, usufrui de uma pseudo-razão ao refletir e fazer escolhas, o que causa um estranhamento ao leitor em se tratando de um romance notadamente realista. O mesmo ocorre quando deparamos com cavalos pensantes em Kholstomér. Tolstói não está apenas fazendo uma alegoria - para ele, e dada a sua intimidade com cavalos, a sugestão do raciocínio em animais é fácil de ser compreendida.

A razão, contudo, "elimina o caminho para a possibilidade" ${ }^{118}$, enfatiza Patterson. E Tolstói, investigando o cotidiano, compreende que, para ter a resposta do sentido da vida, precisa ultrapassar os limites da razão, ao passo que esta não pode relacionar o infinito ao finito, mas somente elementos de uma mesma categoria. No capítulo VIII de Infância, Tolstói teria escrito: "Se raciocinarmos só pelo que as coisas realmente são, então não haverá jogo nenhum! E, se não houver jogo, que restará, então?.." ${ }^{119}$. Essa centelha do artista revelada em sua integridade, na qual a razão perde por completo seu sentido diante daquilo que de fato importa na vida "pós-apocalipse" - a brincadeira, o jogo, a imaginação, a criação -, ou na vida cuja morte é uma possibilidade, retorna a Tolstói quando ele se evade da casta a qual pertence para entrar em contato mais íntimo com aqueles que lhe estavam próximos, mas que, até então, ele não havia, em virtude de um preconceito declarado ${ }^{120}$, levado em conta: os camponeses, o povo comum. Estes, por possuírem fontes de conhecimento diversas das suas; por desempenharem um trabalho que lhes garantia a sobrevivência diária, o pão, o cobertor, o abrigo e a ocupação; por estarem lidando no cotidiano com a concretude da morte possível e não com questões metafísicas sem desfecho; alheios, por conseguinte, aos medos e

\footnotetext{
${ }^{118}$ PATTERSON, David. Op.cit. p. 237

119 TOLSTÓ, Lev. Infância. Tradução do russo: Noé Silva. No prelo, 2012.

${ }^{120}$ Em Uma confissão, Tolstói afirma que só enxergava como humanidade o círculo rico e intelectual de desocupados que ciscavam ao seu redor, enquanto o povo simples, para ele, não era constituído por pessoas reais.
} 
tormentos delirantes que enlutavam Tolstói em sua comodidade, visto que precisavam descobrir "aqui e agora" qual era o sentido da vida, ou então seriam tragados por ela, chamaram a atenção do conde. A realidade "nua e crua" em que estavam inseridos, de luta diária pela existência, conduziu o escritor à dedução de que

O conhecimento racional apresentado pelos bem-educados e sábios nega o sentido da vida, mas a enorme massa de homens, ou seja, toda a espécie humana recebe esse sentido do conhecimento irracional. $\mathbf{E}$ esse conhecimento irracional é a fé, tudo isso que eu não poderia, mas rejeitei. Isso é Deus (...) e todo o resto que eu não posso aceitar enquanto eu retiver minha razão. ${ }^{121}$

Nesse momento, detectamos em Tolstói, mais uma vez, a associação da razão à morte e da vida à ausência de razão ${ }^{122}$. A experiência de Tolstói com o outro, com o novo, abdicando do monólogo em detrimento do diálogo, agindo de forma a sair de si mesmo, onde vivia enclausurado junto à razão ${ }^{123}$, à "Verdade", levou-o a ter uma experiência (o que os camponeses eram compelidos a ter todos os dias) e, a partir dela, aprender. Como resultado, o escritor curvou-se à visão por meio da qual a lei de Deus tornava a vida possível e a morte uma possibilidade. A razão não the parecia mais um valor determinante na arena da fé, na arena do outro. Era imperativo, nesse contexto, sintetizar em seu interior o finito ao infinito com o propósito de libertar-se da morte - e só a fé poderia encarregar-se desse trabalho. A pergunta, portanto, "que sentido tem a vida que a morte não possa destruir?” já teria, segundo Tolstói, uma resposta: “A união com o eterno, Deus" ${ }^{124}$. A fé, para o escritor, era, assim, "o conhecimento do significado da vida humana em conseqüência do qual o homem não destrói a si próprio, mas vive" ${ }^{125}$. Sem ela, o homem não poderia viver. “O que eu sou?” - indaga Tolstói, e emenda: "Uma parte do infinito" 126.

\footnotetext{
${ }^{121}$ TOLSTOY, Lev Nikolayevich. A Confession. Tradução minha. Tradução do russo: Louise Maude e Aylmer Maude. Disponível em: <http://www.ccel.org/ccel/tolstoy/confession.pdf>. Acesso: 15/06/2011. p. 27

${ }^{122}$ Esse ponto será revisto quando analisarmos o conto Três mortes e sua ligação a Rousseau.

${ }^{123}$ Em Uma confissão, Tolstói relata que, até então, só estudava o pensamento daqueles que se encontravam na mesma posição que ele, o que não adiantava nada, uma vez que eles só poderiam ensinar o que Tolstói já sabia.

${ }^{124}$ Ibidem. p. 28

125 Ibidem. p. 29

126 Ibidem. p. 29
} 
$\mathrm{O}$ autor, contudo, a despeito do passo enorme que dera, conta que algo ainda o perturbava, conduzindo-o ao desespero e empalidecendo a esperança que ele agora depositava em Deus: a incoerência com que a maioria dos crentes vivia a fé que diziam professar. Não obstante, Tolstói observa que, diferentemente dos fiéis de seu círculo, a fé do povo era mais verdadeira, autêntica. E relata:

Em contradição à forma como as pessoas de nosso círculo se opõem ao destino e reclamam por causa das privações e sofrimentos, essas pessoas aceitam a doença e o pesar sem qualquer perplexidade ou oposição, e com uma convicção calma e silenciosa de que tudo é bom. (...) Em contraste ao fato de que uma morte tranqüila, sem horror e desespero, é uma rara exceção em nosso círculo, uma morte problemática, insurgente e infeliz é a mais rara exceção entre o povo. ${ }^{127}$

Não bastava, porém, encontrar um sentido para vida "para ter uma morte tranqüila", mas, sobretudo, era incondicional imprimir à existência um sentido prático: religião e vida precisavam andar de mãos dadas dessa vez, suscitando a coerência que ele não detectava no passado. Uma coisa supunha a outra. Ele precisava viver a vida de verdade, livrando-se de sua existência de "parasita"

Verificando que a vida só era possível com fé, depois de uma série de novas crises, Tolstói chega à conclusão de que "Deus é a vida"129. Essa conclusão concederlhe-ia a chave para o bem viver: uma possibilidade para morte. "Eu me salvei do suicídio" 130 - declara Tolstói, que finalmente percebia os limites do intelecto. Era na fé que residia o absoluto que o escritor tanto almejara.

Retornando a Patterson (1978), vemos que as etapas do processo que menciona a metamorfose de quatro aspectos - não se dão, em Tolstói, cronologicamente ou de forma evolutiva, mas cada aspecto emana de um e retorna ao outro de modo um tanto arbitrário, sendo que o movimento de fé vive um estado de eterno recomeço.

Diferente de um personagem de romance que no final não é mais perturbado pelo objetivo da vida, a partir do momento que ele agora o

\footnotetext{
${ }^{127}$ Ibidem. p. 32

${ }^{128}$ TOLSTÓI, Liev. Os últimos dias. Tradução do russo: Anastassia Bytsenko, Belkiss J. Rabello, Denise Regina de Sales, Graziela Schneider e Natalia Quintero. São Paulo: Penguin Companhia das Letras, 2011. p. 25

${ }^{129}$ Ibidem. p. 28

130 Ibidem. p. 28
} 
tem fixado em sua alma, Tolstói continuou tentando elucidar esse objetivo depois de ter sido convertido, se realmente é possível falar em conversão $^{131}$ nesse $^{132}{ }^{132}$.

Em face desse cenário, o movimento de fé empreendido por Tolstói precisava ser por ele mantido de forma a garantir a própria vida. "A crise de Tolstói ao redor da morte clama pela vida agora e para sempre" ${ }^{\# 3}$ - ressalta Gustafson. Para o escritor russo, no entanto, a vida só poderia ser verdadeiramente vida se estivesse pautada por um trabalho impregnado de sentido. É o próprio Tolstói que explica: “A consciência do contínuo processo da morte é útil por que não se pode tê-la sem a consciência da vida que evoca a necessidade de utilizar nossa vida como uma tarefa."134 Tolstói acreditava que, como Cristo, fora enviado ao mundo para uma missão. Ele queria doar à humanidade sua razão e suas "virtudes", encontrando a melhor tradução para tanto na idéia cristã de amor. Essa idéia, no entanto, opunha-se aos desígnios da ortodoxia, possuía um rasgo de inflexibilidade e egolatria que o escritor interpretava como retidão, verdade, o que propiciou sua ruptura com a Igreja, que o excomungaria em 1901.

A procura da fé por Tolstói pela exploração da morte, nas palavras de Gustafson, "se torna uma busca pela identidade a qual irá revelar sua verdadeira vocação." ${ }^{135} \mathrm{Se}$, de fato, esta seria sua verdadeira vocação, ou uma forma encontrada por ele para escapar da morte por meio da negação da vida, no entanto, ainda é um ponto contencioso em face do qual caberia discussão. Nesse debate, a posição de Patterson (1978), para o qual a vida que se descortina no processo de busca é mais vital do que a conclusão encontrada, soa mais contundente. Nessa busca, ao propor a questão com vontade apaixonada, Tolstói nos mostra que a pergunta é de longe mais importante do que a resposta. $\mathrm{O}$ lamento, o questionamento, o movimento, a discussão pesaria mais do que o entendimento. $\mathrm{O}$ segredo não estaria em chegar, mas em como chegamos. $\mathrm{O}$ fato, com efeito, sobre o qual não restam dúvidas, é que Tolstói estava destinado a enfrentar essa crise.

A fim de que nada mais pudesse extraviá-lo do caminho essencial da fé, portanto, suas ações passaram a ser norteadas por um sentido utilitário prático, cujo objetivo era,

\footnotetext{
${ }^{131}$ Não nos cabe analisar aqui, de acordo com parâmetros teológicos, se a conversão de Tolstói se efetivou ou não.

132 PATTERSON, David. Op. cit. p. 242

${ }^{133}$ GUSTAFSON, Richard F. Op. cit. p. 3

134 TOLSTÓI apud GUSTAFSON, Richard F. Op. cit. p. 4

${ }^{135}$ GUSTAFSON, Richard F. Op. cit. p. 4
} 
igualmente, assegurar uma possibilidade para morte. A coerência moral de Tolstói, assim, ao minar o desespero, inibe nele a porção criativa que, isenta de um caráter utilitarista, não serviria aos seus novos propósitos. A literatura, agora, seria um veículo panfletário de exaltação, confirmação, racionalização, acentuação e propagação da fé, cujos efeitos, o escritor acreditava, diziam respeito a todos. Boris Schnaiderman (1983) assinala, contudo, que, a despeito da constante nostalgia que Tolstói sentia pelo trabalho puramente literário, os escritos doutrinários não deixam de lado a garra do escritor, "que introduz personagens e escreve situações humanas, entremeadas às longas digressões, e não obstante alcance, assim, altos momentos de criação". ${ }^{136}$ Não é à toa que a fé também seria difundida na esfera coletiva em oposição à morte advinda de genocídios e massacres, quando Tolstói iria apostar na tese da não-resistência à violência como forma de vencê-la, arrebanhando milhares de adeptos mundo afora. Com relação ao chamado tolstoísmo, Aurora Fornoni Bernadini afirma que a intenção do autor era purgar o cristianismo dos dogmas, dos rituais ou da promessa de vida eterna, reduzindo o Sermão da Montanha a quatro mandamentos:

1) Não querer o mal; 2) Não cometer adultério; 3) Não dar falso testemunho; 4) Não resistir ao mal; e fundamentado em quatro crenças básicas: 1) Existe um Deus, origem de tudo; 2) Há uma parcela da origem divina no homem, que poderá variar conforme suas ações; 3) Para aumentá-la devem-se refrear as paixões e fazer crescer o amor dentro de si; 4) Para consegui-lo deve-se amar o próximo como a si mesmo. ${ }^{137}$

Mais do que nunca, no sentido que vimos no primeiro capítulo, Tolstói é a partir de sua morte, estabelecendo com ela uma relação de distância que deverá ser permanentemente monitorada.

\footnotetext{
${ }^{136}$ SCHNAIDERMAN, Boris. Op. cit. p. 24

${ }^{137}$ BERNARDINI, Aurora Fornoni. O exorcismo da libertinagem em Tolstoi. O Estado de São Paulo: Caderno 2, São Paulo, p. 8, 21 jan. 2001.
} 


\subsection{A própria morte}

Se, por um lado, Tolstói institui uma espécie de seita, o tolstoísmo, para dar à sua fé uma concretude, uma liga, e até para sustentar sua austeridade puritana ${ }^{138}$, uma vez que, após seu desligamento da ortodoxia, seu pensamento religioso não coaduna mais com o oficial ${ }^{139}$; por outro, ele continua arrastando sua vida pelas sendas do "sempre igual". O aristocrata não deixa de gozar das regalias e privilégios próprios a um homem de sua posição, ou seja, aqueles que o dinheiro pode prover - situação que lhe causa ojeriza $^{140}$. Afinal de contas, sem a fé, desempenhada no contexto do cotidiano, ele perderia novamente a noção do sentido da vida, ou pior, estaria traindo tudo aquilo com o qual se havia comprometido. Diante da vida que se vê forçado a levar, o escritor, em 1908, reacende sua relação com a morte: "Minha alma está gravemente deprimida (...). Eu anseio pela morte. (...) escapar dessa vida que está me intoxicando. Socorro, Senhor,

\footnotetext{
${ }^{138}$ Tolstói acreditava na abstinência sexual e de drogas como algo fundamental para manter a fé. Seu rigor puritano ainda incluía outros costumes, como dividir o dia em quatro seções: "Antes do café-damanhã, todos deveriam praticar o trabalho manual e ganhar seu pão pelo suor de seu próprio rosto. Entre o café e o almoço, cada pessoa deveria aprimorar suas habilidades em algum ofício. Do almoço até a tarde todos deveriam se engajar em algum exercício mental. A noite deveria ser reservada para o cultivo de boas relações com outros homens." STEPUN, Fedor. The Religious Tragedy of Tolstoy. Tradução minha. Russian Review, Vol. 19, № 2. Blackwell Publishing, 1960. Disponível em: <http://www.jstor.org/stable/126738>. Acesso: 23/07/2011. p. 166

${ }^{139} \mathrm{Em}$ resposta à resolução do Sínodo que o excomungou, Tolstói teria escrito: "Basta ler o missal e seguir as celebrações incessantemente realizadas pelo clero ortodoxo e examinar a missa cristã para se perceber que todas essas celebrações não são outra coisa senão diversas formas de sortilégio, que se adaptam a todos os acontecimentos eventuais da vida. Para que uma criança, caso morra, alcance o paraíso, é preciso untá-la com manteiga e resgatá-la com a pronunciação de determinadas palavras; para que a parturiente deixe de ser impura, é preciso pronunciar certas fórmulas sacramentais; para se obter sucesso nos negócios ou uma vida tranqüila numa nova casa, para que o pão cresça bem, para que a seca se interrompa, para que uma viagem tenha êxito, para que uma doença se cure, para que a condição do morto no céu seja aliviada, para todas essas e milhares de outras circunstâncias existem certas fórmulas sacramentais que o sacerdote pronuncia em determinados locais e com determinadas recompensas. (...) Um verdadeiro e revoltante sacrilégio é o fato de pessoas servirem-se de todos os meios possíveis, de embustes e hipnotismos para assegurar às crianças e ao povo de alma simples que, ao se cortar de determinada maneira e com certas palavras uns pedacinhos de pão e colocá-los no vinho, Deus se faz presente neles. (...) Seja qual for a maneira de entender a pessoa de Cristo, seu ensinamento (...) foi totalmente distorcido, convertido em grosseiros sortilégios como banhos, unções com manteigas, gestos, fórmulas sacramentais, deglutição de pedacinhos de pão etc., sem que nada reste do ensinamento original". TOLSTÓl. Liev. Resposta à resolução do Sínodo de 20-22 de fevereiro de 1901 e às cartas recebidas nessa ocasião. In: Padre Sérgio. Tradução do russo: Beatriz Morabito. São Paulo: Cosac \& Naify, 2001. p. 120

140 Boris Schnaiderman salienta: "Tolstói arava o solo de sua propriedade, acendia o forno, trabalhava de sapateiro. E, ao mesmo tempo, seus tormentos morais não lhe davam sossego". SCHNAIDERMAN, Boris. Op. cit. p. 35
} 
socorro! A morte é o único lugar para onde se pode ir realmente." ${ }^{141}$ Em vez de assumir a responsabilidade pela incoerência pessoal, no entanto, Tolstói acaba encontrando um bode expiatório: sua esposa, Sófia Andréievna. Não se tratava, porém, de uma mera perseguição sem motivo. Sónia realmente transformara a existência de Tolstói, nos últimos meses, em uma sucessão de tragédias e episódios truculentos, tanto que algumas biografias do autor se apropriaram desse mote de modo a traçar um parâmetro a fim de explorar sua vida, ainda que houvesse outro vilão: Tchertkov ${ }^{142}$.

Primeiro, Sónia recusa-se a mudar seus hábitos para favorecer o ideal de fé do marido, o que consistiria, em resumo, em viver como um simples camponês e no meio destes. "Renuncie aos direitos autorais, abra mão da terra e viva numa cabana" Tolstói ter-lhe-ia proposto. Essa impossibilidade, aliás, até hoje, faz que Tolstói, enfiado em sua célebre túnica, de calções largos e cinta de mujique, sendo um Conde, assemelhe-se a uma risível caricatura - na verdade, a imagem perfeita das contradições que permearam sua vida.

Segundo, ela não admite, em hipótese nenhuma, o relacionamento cultivado pelo marido com Tchertkov, discípulo com o qual Tolstói partilha de enorme intimidade. Ela acredita que eles sejam amantes conspiradores, justificando tal cisma com argumentos sobre a homossexualidade de Tolstói em seu diário ${ }^{144}$, e não tolera que ele confie toda a sua produção literária a Tchertkov, enganando a família, a menos que ela possa controlar tal acesso, visto que Sónia julgava merecer vantagens por ter sido a mais devotada secretária de Tolstói até então. Desavenças tornam-se freqüentes. Sónia cogita formas de matar-se (e algumas das formas incluem tomar ópio ou atirar-se sob um trem, como de Anna Kariênina), acabando por tentar algumas delas, a ponto de mergulhar no lago congelado à época da fuga do marido. Ao que parece, as mortes dos filhos, especialmente a de Vânia, fizeram-na perder a sanidade mental, e seu único objeto de desejo passara a ser, portanto, a obra do marido, que deveria lhe ser garantida em testamento. Diante das ameaças de Sónia de suicidar-se ou de cometer uma sandice, Tolstói e Tchertkov, que de fato vinham tramando legar toda a obra do escritor à

\footnotetext{
${ }^{141}$ TOLSTÓI apud SHIRER, William. Op. cit. p. 301

142 Lavrin observa: "Ele [Tchertkov] logo descobriu alguns pontos fracos no caráter de seu professor e começou a explorá-los para o avanço de seus próprios planos". LAVRIN, Janko. Op. cit. p. 137 143143 TOLSTÓI apud SHIRER, William. Op. cit. p. 372

${ }^{144}$ Sonia relata que, quando rapaz, Tolstói se sentia atraído por homens, adorando participar de atividades como caçadas.
} 
humanidade como propriedade pública ${ }^{145}$, entram no jogo sem imaginar o próximo passo da mulher. O cerco de Sónia, assim, se fecha. Ela não mede esforços para conseguir o que quer e, nesse ínterim, não deixa Tolstói, cuja saúde requer cuidados, privar da solidão, pela qual regenerava seus pensamentos, por um segundo sequer. Ela está sempre ao seu encalço, ou a poucos metros, como uma sombra demoníaca, uma sentinela, sem nenhum receio de humilhação. Os filhos escolhem cada qual de que lado ficar: nenhum, pois se compadecem por ambos: entendem a agonia do pai e testemunham a debilitante loucura da mãe. Apenas Aleksandra, desde o início, manifesta-se como seguidora do pai, e auxilia-o no que é preciso, sem nada questionar. Sob certa perspectiva, a conivência de Tolstói com as idéias testamenteiras de Tchertkov revelavam nele, mais do que uma ânsia de beneficiar os pobres, um desejo de viver para sempre nesse acesso universal que todas as pessoas, sem maiores despesas, teriam à sua obra.

Tolstói decide ir embora, deixar aquela existência de excessos para encontrar o Bem, o campo e, sobretudo, o homem do campo, aninhado à natureza, a fim de completar sua missão na terra, avistando a paz sob a qual Deus se ocultava. Ele teria escrito em seu diário em abril de 1910:

Dores atormentadoras causadas pela consciência da vileza de minha vida circundado como estou por trabalhadores que mal são capazes de se salvar, e às suas famílias, da inanição. Em nossa sala de jantar, quinze pessoas estão se empanturrando com panquecas, enquanto cinco ou seis camponeses que possuem famílias ficam correndo de um lado para o outro, mal sendo capazes de preparar e servir o que devoramos. Sinto-me torturado e extremamente envergonhado. ${ }^{146}$

Em 24 de setembro do mesmo ano, ele deixaria transparecer seu desespero: "Eles estão dilacerando-me e deixando-me em frangalhos. Eu não raro penso em escapar para longe de todos eles". ${ }^{147} 148$ Por essa época, Tolstói pediria instruções a um camponês a respeito de como fugir secretamente e encontrar uma cabana rústica para instalar-se e viver o resto de seus dias. Agora, sim, Tolstói estava disposto a fazer aquilo que não

\footnotetext{
${ }^{145}$ Sob a influência de Tchertkov, Tolstói renunciaria, a princípio, a seus direitos póstumos apenas pelos trabalhos escritos depois de 1881. Depois, entretanto, ele estava sendo coagido a abdicar de todos os seus trabalhos, sem exceção. Tolstói acreditava que tivesse feito um testamento nesse sentido.

146 Ibidem. p. 318

147 LAVRIN, Janko. Op. cit. p. 141

${ }^{148}$ Grifos meus.
} 
fizera: imprimir um sentido à sua vida, convertendo-se verdadeiramente. Era fato que a morte se achegava - e Tolstói clamava por essa possibilidade, pela liberdade. Patterson assinala: “Tolstói não completaria seu movimento de fé até aquela noite em 1910, pouco antes de sua morte, quando ele se levantou como Abraão, sem saber para onde ia." 149

Na madrugada do dia 28 de abril de 1910, portanto, ao ouvir passos de Sónia, que remexia gavetas em seu gabinete, ele percebeu que não havia mais o que ou por que esperar. Estava resoluto. Não poderia mais suportar o assédio daquela mulher em estado demencial. Acordou o Dr. Makovítski e Sacha, temendo que Sónia pudesse surpreendêlo a qualquer minuto. Às seis horas daquela manhã fria, estava tudo pronto. Uma carruagem partia levando Tolstói e seu médico rumo à estação.

No convento de Chamordino ${ }^{150}$, Tolstói encontraria sua irmã, Maria, que se tornara freira, dividindo momentos de relativa paz com ela. Ele até pensou em permanecer no vilarejo, mas desistiu quando fora informado de que Sónia poderia estar a caminho, a despeito dos problemas que vinha causando em Iásnaia Poliana. Tolstói partiria, então, junto à sua “delegação", para Novotcherkassk ${ }^{151}$, uma cidade mais ao sul onde vivia uma sobrinha. Ali, se conseguissem passaportes, rumariam para a Bulgária, se não para o Cáucaso, onde o mestre teria com muitos de seus seguidores. O escritor estava com os nervos à flor da pele, a insônia liquidava-o, e ele, inconscientemente, substituía àquilo que antigamente consistia em um medo da morte, por um medo doentio da mulher, de seu brusco aparecimento, pois agora era ela que, com sua compulsiva e histérica obsessão, estava privando-o da vida - ou da fé. Os "fugitivos", no entanto, na pressa da fuga, esqueciam totalmente que Tolstói era um dos homens mais famosos da Rússia, e que, além do governo, que o considerava um anarquista subversivo, os jornalistas também já deveriam estar à sua espreita.

Em face de tudo isso, no trem, o pânico de Tolstói aumentou. Mantendo a coerência de seu objetivo, ele embarcaria em um vagão de segunda classe, frio, esfumaçado e barulhento. Isso seria letal. Tolstói iria contrair pneumonia ali mesmo, e não restou a ele e a seu grupo outra alternativa a não ser descer na estação seguinte: Astápovo $^{152}$.

Naquele lugar, o que para Tolstói era uma realidade quando partira de casa, se converteria, num átimo, em sonhos embaçados, embaralhados, que debandariam

\footnotetext{
149 PATTERSON, David. Op. cit. p. 242

150 Шамордино

151 Новочеркасск

152 Астапово
} 
conforme sua doença - e a perseguição dos curiosos - avançasse horas adentro. Como não havia nenhuma pensão nos arredores, Tolstói seria instalado na modesta cabana de um agente ferroviário. Uma cabana? Sim. Mas não aquela que o escritor havia imaginado, em um cenário bucólico e perto dos seus. A multidão de curiosos que tão logo abarrotou o lugar, formada por autoridades, jornalistas, tolstoístas e gente comum apinhada de forma a achar o melhor ângulo de visão, transformou o desejo de Tolstói de ter uma "boa morte", sem convergir atenção e aureolada pela paz, tal qual tio Khviédor tivera em Três mortes, em uma quimera.

As indicações de que Tolstói estava insatisfeito com o seu destino, ainda buscando uma possibilidade para morte, resvalava em vários sinais. "E os mujiques? Como morrem os mujiques?"153 - ele indagaria estupefato, duvidando ainda se conseguira se tornar-se, no âmago de seu espírito, um simples camponês (figura por ele em parte idealizada), o que impusera como condição para sua fé. Em outro momento, ele reagiria como o Iván Ilitch de outrora, revoltado em decorrência da morte: "Eis o fim e ele... não é nada! Nada!"154 ${ }^{155}$. Contudo, as derradeiras palavras de Tolstói, balbuciadas de seus lábios no rastro de uma respiração ofegante, seriam condizentes com tudo aquilo que fora sua existência: "Buscar, sempre buscar!" 156 Tolstói, enfim, compreendia que todo o sacrifício, sofrimento, êxtase e glória de sua vida estaria ligado ao que ele jamais deixara de possuir: o apetite pela busca, do qual não tinha medo. Ainda quando encontrava o que vinha procurando, recomeçava seu movimento e voltava a buscar. Foi assim que faleceu Tolstói, no dia 7 de novembro de 1910, no alto dos seus 82 anos: à procura. Desse modo, ele superou a própria morte.

\footnotetext{
${ }^{153}$ TOLSTÓl apud TROYAT, Henri. Op. cit. p. 687

${ }^{154}$ TOLSTÓI apud SHIRER, William. Op. cit. p. 447

${ }^{155}$ No capítulo X de A morte de Iván Ilitch, ocorre o seguinte "diálogo" entre o personagem e sua voz interior: "O que é isso? Será verdade que é a morte? E a voz interior lhe respondia: "Sim, é verdade". Para quê essas torturas? E a voz respondia: "É assim mesmo, para nada". E, além disso, não havia mais nada". TOLSTÓI, Lev. A morte de Iván Ilitch e outras histórias. Tradução do russo: Tatiana Belinky. Barueri: Editora Manole, 2011. p. 93

${ }^{156}$ TOLSTÓI apud STEPUN, Fedor. Op. cit. p. 170
} 


\section{3.}

\section{MORTE E OBRA EM TOLSTÓI}

Até aqui, vimos não só o quanto vida e morte em Tolstói estão irremediavelmente atreladas, mas que os acontecimentos familiares da infância, em especial a perda da mãe, contribuíram em grande parte para a definição de sua personalidade dual. Esta personalidade, por meio da qual o racionalismo falava mais alto, fundaria a relação de aversão inoperante que Tolstói instituiria com a morte, incutindo-lhe um impiedoso desespero - uma sombra da qual ele sempre quis ver-se livre. Só a fé, no entanto, poderia resgatá-lo do breu no qual se isolara, mesmo que para mantê-la ele tivesse de viver uma existência coerente, reta, de acordo com seus preceitos morais, o que, por fim, determinou sua fuga em direção à liberdade de viver como bem quisesse (ou seja, concedendo um sentido à vida que a morte não poderia destruir) - e próximo aos seus. A morte, novamente, atropelá-lo-ia em seu caminho: dessa vez, quando ele tomara a decisão mais incontestável de sua vida. No leito de morte, entretanto, ele valorizaria a si mesmo não pelo que não havia sido ou conquistado, mas por aquilo que sempre fora: um homem em permanente busca. Entender o processo de articulação que Tolstói trava com a morte torna-se, portanto, indispensável para uma compreensão abrangente do seu trabalho.

Neste capítulo, veremos que a frase do autor "Eu sou tudo o que escrevi"157, agora que já investigamos trechos de sua biografia, fará enorme sentido quando analisarmos três de suas obras: A Morte de Iván Ilitch, que marca o "ápice do gênero novela em toda a literatura mundial" "158, Senhor e Servo e Três Mortes. As duas primeiras fazem parte da chamada "fase pós-conversão", quando, segundo Schnaiderman, Tolstói "atinge o máximo de perfeição num gênero que vinha praticando desde moço - a novela -, e que escreve alguns dos seus contos mais extraordinários". ${ }^{159}$ Nessa fase ele também produziria A Sonata a Kreutzer, O Diabo, Padre Sérgio, Depois do Baile, Falso cupom, etc.

Três mortes, conto escrito em 1858, retrocede ao momento em que Tolstói chegava a Iásnaia Poliana após ter dado baixa do exército em 1856. Trata-se de uma

\footnotetext{
${ }^{157}$ TOLSTÓI apud GUSTAFSON, Richard F. Op. cit. p. 6

${ }^{158}$ SCHNAIDERMAN, Boris. Op. cit. p. 26

159 Ibidem. p. 26
} 
leitura que remete às outras, uma vez que o autor entra em contato com a realidade camponesa, com o homem simples do povo, onipresente nessa tríade. Contudo, a questão social aqui, influenciada por Rousseau e imersa na poesia tolstoiana, cujo invólucro é a natureza, é substituída pela mística religiosa lá, sem, no entanto, esmorecer a noção central da humanidade aliada ao amor, evocando tal concepção das relações travadas com a morte em cada contexto.

\subsection{Observações gerais}

\subsubsection{O discurso monológico de Tolstói - Retornando a Bakhtin}

Bitsilli (2001) aponta que, ao delinear sua obra, os poderes espirituais de Tolstói estavam sempre voltados para um elemento: a morte. Esse foco, por sinal, determinava a totalidade de seu trabalho, sendo igualmente a chave para sua fixação mística na vida. Paulo Bezerra afirma o mesmo: Tolstói “achava que só devemos refletir sobre a morte quando temos em vista a vida em sua essência, porquanto" $" 160$ - e aqui ele se aproxima de Blanchot - "essa ou aquela atitude do homem em face da morte define a qualidade de sua vida e a possibilidade de encontrar um sentido para ela."161 Para o escritor, o enigma da morte era equivalente ao enigma da vida - ou, por outras palavras, caso fosse desvendado, o mistério da morte resolveria também o mistério da vida. Tolstói "passou a simbolizar a "vida" ${ }^{162}$. Tal leitura, profundamente humanista, é muito próxima à de Gustafson, para o qual a angústia de Tolstói diante da morte era um ardente e descomunal desejo pela vida. Bitsilli ressalta que as obras de Tolstói representavam um modelo simbólico da vida real na "emigração" (da residência no estrangeiro), na qual, de um lado, ele traçava seu senso de valores humanos e russos e, de outro, contemplava um mundo de cultura alheia, em que a morte em vida era uma realidade. Essa noção se conjuga àquilo que Gustafson chamou no caráter de Tolstói de "Residente" e "Estrangeiro".

Tolstói apresenta um movimento, em que luta rumo ao entendimento do processo pelo qual a morte confere sentido à vida, e outro, em que ele considera que a morte

\footnotetext{
${ }^{160}$ BEZERRA, Paulo. Alienação e Auto-Imolação em A Morte de Iván Ilitch. No prelo, 2011. p. 1

161 Ibidem. p. 1

${ }^{162}$ HARRIS, Jane. Op. cit. p. 74
} 
destitui a vida de sentido. Ele traz à tona, como vimos, uma inclinação mórbida: tem a curiosidade de observar processos de morte, como faz com Nikolai ou Maria - e até consigo mesmo - e, nessa esfera, também narra, com a minúcia que lhe é peculiar, tais processos. "Observando cuidadosamente como as pessoas próximas a ele morriam, é como se Tolstói se tornasse um participante do mistério da morte" ${ }^{\text {163 }}$ - argumenta Bitsilli.

Bakhtin, por seu turno, opõe-se às palavras de Bitsilli ou Gustafson, especialmente quando dá a entender que Tolstói está "longe de ser o poeta da vida vivida, tornando-se, de fato, o poeta da morte." "164 Avesso a determinados vícios do escritor, ele explica como o alicerce monológico no qual Tolstói se ampara incide na maneira falsa como ele representa a morte.

O discurso de Tolstói é criticado por Bakhtin, já que seu "ponto de vista monologicamente ingênuo penetra em qualquer lugar (...) subjugando tudo à sua unidade" ${ }^{165}$, sendo o artifício, para o estudioso, um leque de idealismo que compele à unidade de uma só consciência. Enquanto tal percepção domina, tudo é visto em termos de uma falsa unificação - como o espírito da nação, do povo, da história. "Essa unidade é falsa porque se trata apenas de uma sensação aparente; na verdade" - indica Emerson à luz de Bakhtin - "o monologismo demarca, abstrai, exclui, e é somente de dentro desse sistema hermético e estático que tudo pode ser visto como um". ${ }^{166}$ Nesse sentido, Bitsilli se aproxima a Bakhtin ao afirmar que a intuição da unidade do universo concernente a Tolstói determina sua visão de mundo, "a estrutura de seus enredos, seus personagens e a função destes na história"167. Na corrente oposta, em um universo dialógico, a unidade estaria na diversidade, e a verdade, a bem dizer, seria atribuída a cada indivíduo. Quando a verdade é impessoal, as personagens carregam as idéias que são postas em seus lábios pelo autor. Bakhtin, dessa maneira, discorda diametralmente de Tolstói ao acreditar que o verdadeiro aprendizado é dialógico, horizontal, ao passo que, para o escritor, ele estaria impresso em uma linha vertical. Em condições monológicas, portanto, as idéias não são representadas, mas distribuídas ou expressas diretamente - em última análise, as idéias dos outros deixam de existir.

\footnotetext{
163 Ibidem. p. 81

${ }^{164}$ EMERSON, Caryl. Op. cit. p. 69

165 Ibidem. p. 69

166 Ibidem. p. 69

${ }^{167}$ HARRIS, Jane. Op. cit. p. 84
} 
Na comparação entre Tolstói e Dostoiévski, o teórico observa que as personagens tolstoianas estão de posse de uma verdade que a todos transcende: personagem, leitor, enredo. É isso, aliás, que fornece a certos trechos da obra do autor um cunho "proverbial", no rastro de verdades sem dono e axiomáticas. Em contrapartida, as personagens de Dostoiévski endereçam (ou transmitem) uma idéia a alguém. Na visão de Bakhtin, a verdade impessoal reside no cerne do universo monológico de Tolstói, o que é deslocado para sua obra e para forma como ele representa a morte. A morte em Tolstói estaria impregnada desse teor. Em Três Mortes, por exemplo, as três mortes (da mulher nobre, do cocheiro e da árvore) estão conectadas apenas de modo "externo e mecânico"168. Emerson salienta: "Como os três heróis não estão conscientes uns dos outros, eles podem tornar-se personagens significativos uns para os outros somente em face de uma visão autoritária e autoral que engloba todos". ${ }^{169}$ Bitsilli complementa essa noção ao dizer que os personagens de Tolstói não representam idéias, mas diferentes formas de uma e da mesma vida - ou seja, tanto para Bitsilli quanto para Bakhtin Tolstói trabalha monologicamente. A distinção está em perceber que, para o primeiro, isso é tão somente uma característica do autor que, por sinal, esculpe sua obra vital, enquanto para o segundo, essa dimensão é falsa. Já para Gustafson, é justamente esse discurso que perfaz o Residente, a verdadeira vocação do escritor.

Diferentemente de Dostoiévski, que representa poucas mortes em suas histórias, experimentando um horror de outra sorte, Tolstói representa um grande número de mortes, realçando-as em todas as suas vicissitudes. Segundo Bakhtin, poderíamos até falar de sua paixão em estetizar a morte, visto que ele a exibe sob um ponto de vista tanto externo quanto interno - ou seja, dos recessos da consciência da pessoa que está em vias de morrer, "quase como um fato dessa consciência" $"$ " O interesse de Tolstói pela morte, como já apontou Lavrin, possui um pano de fundo egoísta: está vinculado ao bem da pessoa que morre - a morte advoga em causa própria -, não se constituindo em benefício daqueles que ficam. "Ele é na verdade profundamente indiferente à morte no que tange ao significado deste evento para os outros" ${ }^{, 171}$. No entanto, a morte traçada do ponto de vista interior não existe para ninguém: nem para aquele que morre, nem para os outros.

\footnotetext{
${ }^{168}$ EMERSON, Caryl. Op. cit. p. 73

169 Ibidem. p. 73

170 BAKHTIN apud EMERSON, Caryl. Op. cit. p. 73

${ }^{171}$ Ibidem. p. 73
} 
Tolstói, assim, explora sua posição privilegiada como criador, a despeito de sua visão totalizante reduzir a independência das personagens. "No evento da morte, ele pode estar dos dois lados da fronteira"172: do lado de quem morre e do lado de quem observa o agonizante. Não por acaso, ele acompanhava mortes e, no espaço nãoficcional, julgava saber o que se passava pela mente dos pré-defuntos. Sua filha Macha, segundo ele, estaria tendo uma "revelação". Desse modo, ele também solucionava a questão da morte para a personagem, que encontrava harmonia nesse desenlace. Tolstói se realizava em suas narrativas ao entregar a verdade, a luz, a graça, ao moribundo, assim como reparou seu comportamento ao corrigir, na literatura, o processo de morte que Dmítri tivera na vida real. Dostoiévski, por outro lado, não podia estar dos dois lados da fronteira para apreciar uma resolução dessa espécie. Para ele, a morte não resolvia nada; para Tolstói, ela fechava o quebra-cabeça que vinha montando. Em decorrência disso, Tolstói ignora a tese bakhtiana, destrinchada no primeiro capítulo deste trabalho, segundo a qual "O meu nascimento e a minha morte são eventos apenas para os outros, não para mim" ${ }^{\prime 17}$. Apenas o outro, sob esse prisma, poderia outorgar esse acabamento em nós, isto é: não podemos fazer isso por nós mesmos. Nesse âmbito, tais narrativas soam falsas para Bakhtin justamente porque nelas as cenas de morte estão envoltas em um entendimento luminoso que leva o moribundo a agarrar o mistério da vida, ou o sentido da vida, de modo solitário, na esteira de seus próprios solilóquios. Os outros parecem estar ali apenas como projeções de uma consciência, a exemplo da figura antagonista expressa pelo homem do povo, pelo camponês, pelo mujique russo. Não há diálogo. Reside, nesse processo de autossuficiência, uma mentira, uma vez que nenhuma personalidade pode ser controlada ou criada a partir de seu interior. "Podemos ser concluídos, apenas, a partir de uma perspectiva exterior" ${ }^{״ 17}$. Nessa trilha, para Bakhtin, Tolstói dispensa muito rapidamente o outro; e o teórico, não à toa, se volta para Dostoiévski, no qual a necessidade do outro é absoluta.

Sem sombra de dúvida, é no diálogo que habita o desenvolvimento pessoal. A prova clara disso é o indivíduo afetado pelo autismo ${ }^{175}$ que, por não conseguir relacionar-se com o outro - travar um diálogo com o próximo -, não se desenvolve, não

\footnotetext{
172 Ibidem. p. 74

${ }^{173}$ EMERSON, Caryl. Op. cit. p. 74

${ }^{174}$ BAKHTIN apud EMERSON, Caryl. Op. cit. p. 74

${ }^{175}$ Lorna Wing definiu o autismo como uma síndrome que apresenta comprometimentos em três importantes domínios do desenvolvimento humano: a comunicação, a sociabilização e a imaginação. A isto, ela deu o nome de tríade. Disponível em: <http://www.ama.org.br/html/info_conc.php>. Acesso: 09/08/2011.
} 
aprende, ou apresenta algum retardamento. Em casos mais críticos, o autista nada consegue criar, mas apenas reproduzir. Encarados sob esse ângulo, os apontamentos de Bakhtin acerca das personagens agonizantes de Tolstói, sempre prestes a ter uma revelação inaudita à beira do "cadafalso", soam contundentes. Por outro lado, é preciso considerarmos as intenções do autor no momento em que escreve. Tolstói era um homem de caráter profético, revolucionário, de muitas intenções, portanto, que se desdobrariam no esteio da leitura. Elas, não raro, insufladas pela ânsia de transformar seu público pelas vias do amor, sem dúvida justificam quaisquer "faltas", nos termos explorados por Bakhtin, do escritor de Iásnaia Poliana.

\subsubsection{Deus, o amor, a vida, o outro e o bem}

No conto De que vivem os homens ${ }^{176}$, escrito em 1885 , Tolstói conta a história de Semion, um sapateiro muito pobre que, enquanto volta para casa, sujeito ao frio, à fome e à miséria, é açoitado por uma imagem surpreendente e real: um homem que, desnudo e desfalecido, aferra-se à pilastra de uma capela. Quem é esse homem? Não importa. O que está em jogo para Tolstói nessa encruzilhada é a capacidade de ser (na acepção do verbo) humano inerente a Semion. Se ele optar pelo bem, demonstrando amor pelo homem, compadecendo-se pelo outro, ele estará optando pela vida. Do contrário, se ele for indiferente ao sofrimento do homem, ele estará voltado para si mesmo, escolhendo o mal, e, portanto, a morte. O anjo Mikhail, que se transubstancia em homem, no caso, é capaz de identificar tais mudanças nos semblantes dos personagens.

Mencionamos a narrativa porque ela demarca com muita propriedade e didatismo a lógica que permeia boa parte da obra de Tolstói. O primeiro parágrafo de Anna Kariênina, por exemplo, repousa sobre tal lógica: "Todas as famílias felizes se parecem, cada família infeliz é infeliz à sua maneira." ${ }^{177}$ Como já vimos, para Tolstói, "Deus é a vida", e a felicidade só pode existir quando estamos em comunhão com Deus, com a vida, com o bem, com o outro. Por isso, as famílias felizes se parecem entre si. Por seu turno, apartadas de Deus, vivendo cada qual segundo seus próprios parâmetros, as famílias infelizes constituem-se de membros isolados em seus mundinhos fechados,

\footnotetext{
176 Чем люди живы

177 TOLSTÓI, Liev. Anna Kariênina. Tradução do russo: Rubens Figueiredo. São Paulo: Cosac Naify, 2005. p. 17
} 
diferentes entre si, sem fomentar nenhuma iniciativa rumo ao bem, ao outro. Essas famílias, ou indivíduos, segundo o pensamento tolstoiano, estão mortas. São mortos em vida. Nesse sentido, Gustafson ressalta que a busca de Tolstói reside em transformar "o Estrangeiro que está às portas da morte em um Residente da vida"178. Passemos ao exame pormenorizado de suas obras.

\subsection{A Morte de Iván Ilitch}

Como em Anna Kariênina, cuja história se fundamenta em bases reais, a inspiração de Tolstói para escrever A morte de Iván Ilitch veio da morte de um conhecido chamado Iván Ilitch Miétchnikov. Este fora um promotor de justiça em Tula que falecera de câncer em 1881, aos 45 anos. Ironicamente ou não, Tolstói o descrevia como "um homem muito agradável"179 . No tempo em que permaneceu em Iásnaia Poliana, Miétchnikov se tornaria verdadeiramente ligado ao escritor - e talvez ele achasse que aquele homem não cultivasse nenhuma grande virtude para fasciná-lo tanto, o que o intrigava. Difícil saber. Outro dado, ressalta Robert Russell apoiando-se em artigo de N. F. Golubov, é que os pormenores médicos da doença de Miétchnikov, bem como a forma como morreu, coincidem quase inteiramente com aqueles que levaram a personagem da novela à sepultura. O que não significa que Miétchnikov e a personagem de Tolstói fossem a mesma pessoa, até porque Tolstói gostava de Miétchnikov. O episódio, na verdade, revela o quanto impressionava o autor a morte repentina de alguém, tendo ele aproveitado o mote para retratar um arquétipo do homem comum, "uma espécie de russo qualquer"180, tal qual pontua Russel.

\subsubsection{Capítulo Um}

O curioso nas páginas iniciais de A morte de Iván Ilitch, cujas cenas percorrem o período imediatamente após a morte do protagonista, é observar como Tolstói abre no

\footnotetext{
${ }^{178}$ GUSTAFSON, Richard F. Op.cit. p. 193

${ }^{179}$ RUSSEL, Robert. From Individual to Universal: Tolstoy’s “Smert’ Ivana Il'icha”. Tradução minha. The Modern Language Review. Vol. 76 no 3. Modern Humanities Research Association. Disponível em: <http://www.jstor.org/stable/3727398>. Acesso: 10/06/2011. p. 637

${ }^{180}$ Ibidem. p. 637
} 
texto janelas pelas quais o leitor pode entrever o que o espera nos próximos capítulos: as contingências que irão acometer Iván e o papel de cada personagem nesse processo. Em uma segunda leitura, vemos que toda a história está ali. Essas janelas são os olhos de Piotr Ivánovitch.

Ex-colega de trabalho de Iván, como aqueles reunidos no gabinete de Chebek, Piotr, em um primeiro momento, não se comporta de maneira diferente dos outros: também vibra ao pensar no lugar que o "amigo" deixa vago e desfruta de certo alívio, ao verificar de que foi Iván quem morreu, não ele. Gustafson acrescenta: "A missão da vida para ele é a busca de uma posição melhor, independentemente dos outros, e nisso ele se parece com os outros." ${ }^{\text {181 }}$ São nessas aparências, portanto, que toda a amizade é fundada, "pois essas pessoas são aquelas que gostam umas das outras por que elas se parecem entre si". ${ }^{182}$ A vida deve ser, desse modo, agradável e adequada, em um esforço de "se tornar parecido no intuito de ser querido" 183 Contudo, em face das conveniências sociais, Piotr decide comparecer ao velório. Lá, esbarra logo na entrada com Schwarz, que lhe soa excessivamente senhor de si a despeito do "caráter brejeiro" 184 , nada afetado pela situação e ávido pelo jogo, o whist da noite, o que indica ao leitor que espécie de pessoa era Iván Ilitch - uma farsa tal qual seus supostos amigos. Paulo Bezerra observa que o fato de os colegas de Iván tomarem conhecimento de sua morte pelo jornal "traduz (...) o sistema de relações afetivas e sociais que impera naquela repartição pública" ${ }^{185}$, o que "revela a fria indiferença burocrática pelo destino do colega durante sua prolongada doença" $" 186$.

Nessa trilha, Piotr depara com o mujique-copeiro Guerássim, o qual, exercendo o papel de enfermeiro - lembra Piotr -, havia despertado um sentimento de afeto peculiar em Iván. A essa altura, o leitor já pode cruzar informações de suma importância: apesar de se tratar de um janota da pior estirpe, encostado na Corte Judiciária, valendo-se, provavelmente, de um bom ordenado, Iván se identificava especificamente com o camponês que lhe servia.

Em seguida, Piotr, como em um plano-sequência, chega ao cômodo onde jaz o defunto. Tolstói não perde a oportunidade de descrever pormenorizadamente as




características do cadáver, salientando que em sua expressão ele repreende os vivos, o que desagrada Piotr, nitidamente perturbado pela "presença" de Iván. Algo da experiência da morte de Iván, dos desprazeres por que passou, insiste, desse modo, em se comunicar com Piotr e retirá-lo do mundo onde uma partida de whist é o que há de mais fenomenal, mas este, ainda que abalado, foge ao contato. Shwarz, o mundo de fantasia do qual Iván se livrara, está, naquele espaço, sempre ao encalço de Piotr, alertando-o e fazendo um contraponto com o universo real da morte, do serviço fúnebre, do odor da decomposição do corpo - e os dois hemisférios são bem demarcados por Tolstói.

No decurso das exéquias, ao conversar com Prascóvia Fiódorovna, Piotr entra em contato com a dor de Iván, um homem que conhecera intimamente desde garoto. Ele considera que não estaria isento de sofrer o mesmo, a qualquer hora, manifestando uma preocupação que se restringe tão somente a si: “(...) por um momento fícou apavorado" "187. Mas Schwarz está logo ali para fazê-lo crer que eles são "imortais". Ou, como pensaria Iván Ilitch algumas páginas adiante: Só Caio é mortal. Gustafson pontua: "Piotr Ivanovitch é aquele que está distante mesmo quando perto". ${ }^{188}$ Já Robert Russel adverte que o "sentimento de Piotr aqui antecipa os sentimentos de Iván Ilitch sobre a morte em geral, ou a morte de Caio de um lado, e sua própria morte de outro."189.

Prascóvia Fiódorovna continua a adular Piotr e, na primeira oportunidade, revelalhe seus reais e espúrios interesses: extrair, em face da morte do marido, o tanto quanto possível do dinheiro do Tesouro, e cobre-o de perguntas. A viúva, de súbito, mostra-se ao leitor: ela jamais conseguira aproximar-se de Iván com tato em seu caminho rumo ao ocaso - e esse é mais um sinal do sofrimento moral do qual foi vítima. Segundo Paulo Bezerra, como a ação da viúva se desenrola na sala contígua, em que o corpo do marido está sendo velado, "o autor põe a família de Iván Ilitch no mesmo sistema de consciência coletiva de seus colegas burocratas. Família e burocracia, juntas, fazem parte de um mesmo sistema de valores, do mesmo ciclo da morte no qual Iván Ilitch imolou-se em vida" $" 190$.

Outras figuras trafegam pelo estranho e cingido território que é a casa do morto: sua filha, que, como a mãe, olha para Piotr ávida para que aquele espetáculo macabro

\footnotetext{
${ }^{187}$ TOLSTÓI, Lev. A morte de Iván Ilitch e outras histórias. Tradução do russo: Tatiana Belinky. Barueri: Editora Manole, 2011. p. 25

${ }^{188}$ GUSTAFSON, Richard F. Op.cit. p. 155

${ }^{189}$ RUSSEL, Robert. Op.cit. p. 632

${ }^{190}$ BEZERRA, Paulo. Op. cit. p. 3
} 
termine e seu conto de fadas prossiga, e Volódia, o filho ginasiano, único da família que parece estar de fato comovido. Piotr, no entanto, não dá mais chances à atmosfera deprimente e se retira. Contudo, topa com Guerássim que, a uma indagação sua, puramente retórica, responde: "É a vontade de Deus. Para lá iremos todos"191. O leitor finalmente entende o que Guerássim tinha de diferente - e que Iván Ilitch, decerto, compreendera: ele não fazia parte do conto de fadas sustentado pelos outros e que, por algum momento, sabe-se lá em que circunstâncias, talvez na proporção em que morria, Iván deixou de apreciar. Os olhos de Piotr, assim, se fecham para o carteado.

Sobre essa horda de indivíduos que, tal qual Piotr, prescindem da humanidade em detrimento de uma diversão inócua, o filósofo dinamarquês Kierkegaard adverte:

E bem longe de, como supõe, não serem desesperados todos aqueles que não se sentem ou supõem, e de só o serem aqueles que o confessam, muito ao contrário, o homem que sem imitação afirma o seu desespero não está tão longe da cura, está mesmo mais próximo do que todos aqueles que não são considerados e não se julgam desesperados. Mas a regra é, precisamente (...) que a maior parte das pessoas vive sem grande consciência do seu destino espiritual... e daí toda essa falsa despreocupação, essa falsa satisfação em viver, etc., etc., que é o próprio desespero ${ }^{192} 193$.

Tolstói, por sua vez, acredita que o maior medo do homem não reside na morte, mas em uma vida falsa. A morte física acabaria por demonstrar aos homens a necessidade de algo que eles não possuem: uma vida verdadeira. E na trilha de Kierkegaard, pontua: "Esse é o motivo pelo qual o homem que não compreende a vida não gosta de pensar na morte. Para ele pensar na morte é o mesmo que admitir que ele não vive como demanda sua consciência". ${ }^{194}$ Novamente, esbarramos na idéia que dá

\footnotetext{
${ }^{191}$ TOLSTÓI, Lev. A morte de Iván Ilitch e outras histórias. Tradução do russo: Tatiana Belinky. Barueri: Editora Manole, 2011. p. 28

192 Grifos meus.

${ }^{193}$ KIERKEGAARD, Sören. O desespero humano. In: Col. Os Pensadores. São Paulo: Victor Civita, 1979. p. 206

194 TOLSTÓI apud PACHMUSS, Temira. The Theme of Love and Death in Tolstoy's the Death of Ivan Ilyich. Tradução minha. American Slavic and East European Review. Vol. 20, no 1. Association for Slavic, East European, and Eurasian Studies. Disponível em: <http://www.jstor.org/stable/3001246>. Acesso: 10/06/2011. p. 75
} 
corpo à aventura tolstoiana - isto é, a de que o entendimento da vida implica, necessariamente, sondar o campo minado da morte.

Segundo Martin Heidegger - que se inspirou na obra de Tolstói em seu empreendimento existencialista -, "morre-se", ou seja, trata-se de algo impessoal. As pessoas conhecem casos de morte aqui e ali, ouviram falar de algo, mas não é nada com o qual se envolvam. Assim se desenrolaria o modo de ser do ser-para-a-morte ${ }^{195}$ cotidiano. Quando Iván, no entanto, se refere a Caio, o homem abstrato, como mortal, muito embora ele e seus amigos não o sejam, ele está dizendo: "algum dia, por fim, também se morre mas, de imediato, não se é atingido pela morte". ${ }^{196}$ Assim, sobre a postura dos amigos e familiares no decurso do sofrimento de Iván, que se recusam a olhar a morte nos olhos, um vaticínio óbvio inscrito na aparência da personagem, Heidegger acrescenta:

É desta maneira que o impessoal busca continuamente tranqüilizar a respeito da morte. No fundo, essa tranqüilidade vale não apenas para o moribundo, mas, sobretudo, para aqueles que o consolam. (...) Não é raro perceber a morte dos outros um desagrado e até mesmo uma falta de tato social de que a publicidade deve se precaver. ${ }^{197}$

O moribundo, alerta Haddock, é a metonímia da presença da morte. Por este motivo, eles incomodam e são varridos da sociedade - para que esta "possa prosseguir fingindo sua imortalidade, apoiando-se na mortalidade abstrata de Caio, o ser que pode morrer"198.

Prosseguindo à análise do capítulo, Irving Halperin pergunta: "Por que a abertura da novela se dá com personagens secundários no palco?"199 Ou seja, por que a narrativa está cronologicamente invertida? Bom, segundo o próprio Halperin, essa estrutura está de acordo com a descoberta irrevogável feita por Iván no final da história: a de que "o fim aparente da consciência humana, a morte, é na realidade o começo da vida". ${ }^{200}$ Há uma "vida após a morte" para Iván, e isso não se vincula absolutamente a concepções

\footnotetext{
${ }^{195}$ A expressão ser-para-a-morte significa que todos somos indivíduos que vivemos para um dia morrer. 196 HEIDEGGER apud HADDOCK-LOBO, Rafael. O Ser e a Morte. Anuário de Filosofia São João Del-Rei, no 10, 2003. p. 280.

197 Ibidem. p. 281

198 HADDOCK-LOBO, Rafael. O Ser e a Morte. Anuário de Filosofia São João Del-Rei, no 10, 2003. p. 281.

${ }^{199}$ HALPERIN, Irving. The Structural Integrity of the Death of Ivan Ilitch. Tradução minha. The Slavic and East European Journal. Vol. 5 no 4. American Association of Teachers of Slavic and East European Languages, 1961. Disponível em: <http://www.jstor.org/stable/305122>. Acesso: 10/06/2011. p. 335

200 Ibidem. p. 335
} 
espíritas. Sendo o primeiro capítulo, encarado sob o prisma cronológico, o último episódio da história - o anúncio da morte de Iván Ilitch -, há indubitavelmente uma ênfase do papel da morte na narrativa: ela protagoniza. Trata-se de uma novela sobre a morte, sobre um morto. E o que importa, nessa trajetória, não é o fato de Iván ter morrido, mas a forma como ele morreu, o que fica claro no decorrer da leitura. Para Robert Russel, essa transposição "permite que Tolstói se refira à vida de Iván Ilitch já

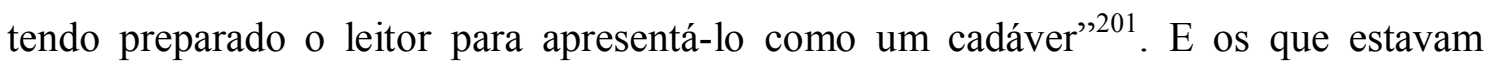
vivos, pelo visto, tinham uma existência tão estéril quanto aqueles que já a haviam finalizado.

\subsubsection{Uma personagem sempre "agradável" e "apropriada"}

Após o fim, Tolstói retrocede ao começo. E, em um primeiro momento, ele irá responder à pergunta a respeito de quem é, afinal, esse Iván Ilitch cujo velório foi por nós acompanhado pelos olhos de Piotr.

O pai de Iván, como ele, passara a vida subjugado à própria incompetência - que, não por acaso, encontrou um cano por onde escoar: a burocracia pública, da qual, graças ao tempo de serviço, títulos e posições agregadas, ele não poderia ser demitido. $\mathrm{O}$ segundo de três filhos, Iván Ilitch, dada a uma espécie de intuição classista, sempre seguira a vida como "manda o figurino". Tolstói pontua: "um homem bem dotado, alegre, gentil e sociável, mas severamente cumpridor daquilo que considerava seu dever; e reputava como dever tudo aquilo que era assim considerado pelos superiores hierárquicos. ${ }^{202} \mathrm{Na}$ realidade, ele era aquele tipo de indivíduo que, em decorrência de um confrangido medo inconsciente (como vimos em Kierkegaard), tenta dar à sua vida o tom do ambiente social, nem mais, nem menos, a fim de não dissonar.

As aparências que o guiavam na vida exterior, por mais inconcebível que isso possa parecer, também preenchiam sua existência interior - e ele não cultivava nenhuma elucubração existencialista de natureza mais densa, nem, por outro lado, mantinha dentro de sua casa, junto à mulher e aos filhos, o que seria o natural, uma personalidade mais emotiva, visceral. Não, Iván não tinha vísceras. Ele era liso, vazio,

\footnotetext{
${ }^{201}$ RUSSEL, Robert. Op.cit. p. 630

202 TOLSTÓI, Lev. A morte de Iván Ilitch e outras histórias. Tradução do russo: Tatiana Belinky. Barueri: Editora Manole, 2011. p. 30
} 
como suas camisas limpas ou as palavras francesas que emitia no momento oportuno, "com a aprovação das pessoas mais altamente colocadas"

Os adjetivos que Tolstói atribui a Iván - decente, comedido, bon enfant, agradável, tranqüilo, inteligente, vivaz, contido, formal, jovial, elevado, espirituoso, benévolo, correto -, reiterados copiosamente, são duplamente empregáveis, já que tudo o que Iván poderia guardar de mais basilar em sua alma constituía-se no que ele já exibia, na verdade, no plano externo. Ou seja, pondo-o pelo avesso, nenhuma mudança se faria visível. "A mecanização racional penetra até a alma do trabalhador" Marx. O texto, propositalmente, soa redundante, uma vez que não há nada a dizer sobre Iván além de palavras que gravitem ao redor de "apropriado" ou "agradável".

No capítulo III, Tolstói joga com essa idéia, quando descreve a incrível habilidade de Iván para "separar o lado oficial, sem misturá-lo com sua vida real"205 - o que seria um talento. E prossegue: “(...) até permitir-se às vezes, como que por brincadeira, mesclar relações humanas com relações de serviço"206 207 . Primeiro, Iván Ilitch jamais poderia relacionar-se de maneira humana com alguém (e muito menos "descartar o lado humano") porque ele não era dotado de nenhum resquício de humanidade. Iván era como uma pintura egípcia, só continha um lado. Depois, ele não poderia separar o "lado oficial" da "vida real", visto que deambulava por um conto de fadas, em que, por princípio, a chamada "vida real" inexiste. Descrevendo tanto o ambiente da casa quanto o do trabalho, Tolstói reforça o argumento de que Iván não apresentava gradações em sua personalidade:

Pouco depois, não mais do que um ano após o casamento, Iván Ilitch compreendeu que a vida familiar, embora apresentasse algumas comodidades, constituía, na realidade, uma coisa muito complexa e penosa, perante a qual, para cumprir seu dever, isto é, levar uma vida digna e aprovada pela sociedade, era preciso desenvolver certas relações, do mesmo modo como perante o próprio serviço público. (...) Ele exigia da vida conjugal apenas o conforto que ela podia oferecer das refeições caseiras, de dona de casa e de cama, e, principalmente, aquele decoro na aparência, determinado pela opinião pública. ${ }^{208}$

\footnotetext{
203 Ibidem. p. 33

204 MARX apud LUKÁCS, Georg. História e Consciência de Classe. São Paulo: Martins Fontes, 2003. p. 202

205 Ibidem. p. 49

${ }^{206}$ Ibidem. p. 49

${ }^{207}$ Grifos meus.

208 Ibidem. p. 38
} 
A coisa "complexa e penosa", à qual Tolstói se refere, seria esse lado humano que, por não conhecer, Iván Ilitch não entende. Por fim, ele resolve tratar disso como mais uma relação de serviço - ladainha por ele já decorada. Mais à frente, o escritor sublinha, corroborando o que já dissemos: "No mundo do serviço público concentrou todo o interesse da sua vida. E esse interesse o absorvia". ${ }^{209}$ Bezerra (2011) afirma que a diluição de Iván na estrutura do sistema jurídico é tão intensa que até a família se torna um estorvo perante sua carreira. Robert Russel ratifica nossa reflexão:

Nem na sua vida social, nem na sua vida oficial, Iván Ilitch e aqueles como ele aceitam outros seres humanos simplesmente como pessoas. As atitudes de superficialidade social e correção oficial cuidadosamente desempenhadas impossibilitam a humanidade. As pessoas são cadáveres, casos legais, apêndices, maus cheiros: qualquer coisa, menos seres humanos. ${ }^{210}$

Para Iván, expressar o lado humano, na verdade, correspondia a expressar o lado social, a conversar sobre conteúdos que não dissessem respeito diretamente ao aspecto oficial, apesar de, no que tange à forma, ele agir invariavelmente de modo igual: como um ente funcional. Em um determinado ponto, Tolstói arremata: “As alegrias do serviço eram as alegrias do amor-próprio, e as alegrias sociais eram as alegrias da vaidade; mas os verdadeiros prazeres de Iván Ilitch eram os prazeres do jogo de whist." Entre as expressões "alegrias do amor-próprio", "alegrias da vaidade" e "prazeres de Iván Ilitch" não há substancialmente diferença nenhuma. A repetição da idéia aqui implicada se dá no intuito de mostrar que não havia nenhuma variante no caráter de Iván Ilitch - ele era apenas uma coisa só e unilateral.

É notório, cabe dizer, como o texto de Tolstói é irônico ao relatar a história, especialmente antes da "queda", como uma narrativa que Iván Ilitch certamente consideraria "agradável", pela aparente ausência de perspectiva, enquanto, na verdade, a crueldade de Tolstói é arrebatadora. Um exemplo de tal ironia ocorre na medida em que a personagem, esse homem "capaz de separar seus deveres oficiais da sua vida privada"211 (que, por sinal, também inexistia, uma vez que ele passava em casa apenas

\footnotetext{
209 Ibidem. p. 39

${ }^{210}$ RUSSEL, Robert. Op.cit. p. 638

211 Ibidem. p. 33
} 
para "bater ponto" e para merecer o "respeito geral") é colocado como alguém mais louvável por tratar com "camaradagem" as pessoas que dele dependiam juridicamente. "Eis que ele, que podia esmagá-las, tratava-as amigavelmente, com simplicidade"212. Iván Ilitch até poderia ter uma postura digna, se se balizasse por valores éticos, morais, humanos, para, enfim, "respeitar" as pessoas independentemente do vínculo de trabalho que com elas possuía. Como sua existência, porém, era um emaranhado burocrático, uma mimetização risível do cacoete classista que a ele se avizinhava, o que o conectava a todos resvalava sob o pretexto do serviço, do ofício. A "camaradagem" se dava unicamente nesse plano. O salto estilístico do grande autor, no entanto, está (alimentando a farsa) na frase que vem em seguida: "Homens assim havia poucos naquele tempo" ${ }^{\text {213 }}$. Sim. Tolstói conta a história de Iván Ilitch como a personagem a contaria, e é importante notar que é daí que exala muito de sua ironia.

Seguindo essa linha, em um trecho da novela Tolstói escreve que Iván "pegou um romance de Zola” ${ }^{214}$. O que já se daria no âmbito do absurdo quase gogoliano - Iván se apossar de um Zola ${ }^{215}$-, é remediado por Tolstói - "mas não o lia, estava só pensando" 216 . É como se o escritor se sentisse devedor de uma imediata explicação ao leitor: “fiquem calmos, não me trucidem, ele não o lia! Ele não o lia!!!”, muito embora o fato descortine até que nível pode alçar um indivíduo dessa categoria para continuar soando "apropriado". Não há limites, visto que "parecer", nessa ciranda, é "ser", como vai observar Rousseau. Ademais, como mostraremos adiante, só um homem poderia ler Zola, e o pobre Iván Ilitch não era um homem - ou, pelo menos, não dava indícios de que fosse um.

\subsubsection{A desumanização de Iván}

A palavra reificação, que designa bem o processo pelo qual Iván extermina todo e qualquer valor humano de seu campo sensível, etimologicamente, provém do latim res, ou seja, coisa. Trata-se de um processo pelo qual algo, inclusive uma abstração,

\footnotetext{
212 Ibidem. p. 34

213 Ibidem. p. 34

214 Ibidem. p. 65

215 Émile Zola (1840 - 1902), escritor francês conhecido pela literatura naturalista e engajada e pelo caráter libertário.

216 Ibidem. p. 65
} 
transforma-se em coisa tangível materialmente calculável para encaixar-se na escala de produção ${ }^{217}$ a fim de que possa ingressar no mercado capitalista, onde tudo tem o valor de coisa. E por que tudo tem o valor de coisa no mercado? Porque - dito de outra forma - uma coisa é calculável e, apenas assim, possuindo um valor calculável, é que ela se torna um insumo para produção e pode, enfim, ser trocada, ser comercializada como produto. Para transformar algo em coisa é necessário extrair todos os valores nela contidos que não são calculáveis. Valem, nesse trânsito, apenas valores materiais. Valores humanos, a exemplo do amor de pai ou de mãe, são sumariamente desconsiderados, pois não podem ser calculados, o que o sistema capitalista não aceita. Dentro dessa lógica, tudo e todos são afetados: o homem, criando novos hábitos, valores, outra rotina, refazendo sua cultura, pode vir a tornar-se objeto, insumo, produto, pois, como vimos, para encaixar-se ${ }^{218}$ na dinâmica é preciso converter-se em coisa. Bezerra registra: "É bem verdade que Iván Ilitch não participa da produção de objetos materiais, base do processo de reificação, mas integra a superestrutura jurídica que dá sustentação ideológica ao sistema de relações econômicas e sociais." ${ }^{219}$

Passando a uma análise comparativa entre Tolstói e Brecht ${ }^{220}$, percebemos que, no sentido acima esmiuçado, há um fio que tece um elo entre as personagens Iván Ilitch e Galy Gay - este último da peça Um homem é um homem de Bertolt Brecht. Os dois são indivíduos que ganham "substância" na proporção em que as sociedades em que vivem apresentam suas demandas. Tais transformações são a um só tempo visíveis, decisivas e essenciais para o desenvolvimento de ambas as histórias, revelando, por conseguinte, dimensões cujas arestas se estendem - sejam elas psicológicas, como as tensões que afligem Iván, ou identitárias, no caso de Galy Gay.

Na peça Um homem é um homem, escrita em 1924, o dramaturgo conta a história de Galy Gay, um estivador que não sabe dizer "não", sendo, portanto, uma espécie de saco vazio útil como repositório à conveniência do comandante ocasional. Ambientada em 1925, na Índia, ela trata da metamorfose pela qual passa Gay, que de simples civil é transformado em um soldado abjeto. Após dizer à esposa que vai comprar peixe, ele é fisgado por três soldados que roubaram o dinheiro de um templo à custa da perda de um companheiro de nome Jeraiah Jip. O sargento já estaria em polvorosa, à cata daqueles

\footnotetext{
${ }^{217}$ Escala de produção: processo em que a matéria-prima se transforma em mercadoria.

${ }^{218}$ Aqui, no sentido de deformar uma forma para que caiba em algo.

219 BEZERRA, Paulo. Op. cit. p. 10

${ }^{220}$ Essa análise se faz no intuito de, na comparação, entender melhor o processo de desumanização que atravessa o personagem.
} 
saqueadores de templo. Por esse motivo, o trio de soldados precisaria urgentemente encontrar alguém para colocar no lugar do desaparecido - e para, sobretudo, desempenhar a função de quarto operador de metralhadora. Os soldados oferecem a Gay cigarros e cerveja em troca de que ele assuma a identidade do defunto - e ele, em nenhum momento, reluta em fazê-lo. Nesse rastro, concedem-lhe a propriedade de um elefante imaginário do exército. Ele então é preso por "propriedade ilegal", sentenciado e executado em um imbróglio no qual se efetua uma lavagem cerebral, fazendo que Gay abrace a identidade de Jip voluntariamente.

Seu discurso é o de um sujeito incapaz de cultivar o valor que seja, a menos que tanto mais vazio o indivíduo, mais estimado na sociedade de consumo ele seja, onde tudo é mercado, tudo é orgia capitalista, tudo é anti-cidadania, o que vai dar ensejo para que aqueles que o cercam o manipulem. Um homem como Galy Gay, afinal, é o consumidor por excelência, como aquele que deambula pelo shopping e é içado por diferentes lojas feito um peixe pelo anzol: qualquer produto lhe serve, qualquer perfil é o seu. A eterna insatisfação, ou sensação de falta, seria a lenha de tal fogueira.

É apelando aos instintos mais básicos, desse modo, como comer ou beber (o que o aproxima de um animal, portanto ${ }^{221}$ ) que Galy Gay assume a faceta do falecido Jeraiah Jip. Seria como se Gay, por ser pobre, fosse um criminoso em rota de fuga, tendo de assumir múltiplas identidades nesse percurso a fim de não ser capturado - ainda que, para isso, tenha de renegar a esposa, manchar por completo a sua reputação e, em seguida, morrer e ser sepultado. Ressuscita, enfim, besuntado na função de soldado. $\mathrm{O}$ homem, a despeito de deixar de "ser", não deixa de ser um homem perante a comunidade. O espírito gerido pelo Capital declara as suas contradições, chega ao seu ápice e, por impossibilidade de compra, Gay vende-se por inteiro, arreganhando a própria alma e tendo como única fonte e força de trabalho a capacidade de não-ser, a habilidade profícua de moldar-se estéril àquilo que lhe garantirá ao menos um prazer irrisório. Pautados na teoria do filósofo húngaro Georg Lukács, poderíamos dizer que, desde o início da história, Gay, inclusive pela forma como se dirige à mulher ${ }^{222}$, anseia desesperadamente fugir da Lei Social Natural ${ }^{223}$, à qual deve subserviência e, ainda que

\footnotetext{
${ }^{221}$ Paulo Bezerra observa como em A morte de Iván Ilitch, o protagonista desce a um nível zoomórfico, já que se comporta, segundo o narrador, como uma mosca atraída pela luz.

${ }^{222}$ Gay se dirige à mulher de forma empolada e tentando empregar uma linguagem rebuscada, o que é incoerente e "estranho" no que concerne a um simples estivador.

${ }^{223}$ É a lei que, em vez de ocorrer no espaço da natureza, ocorre no espaço da sociedade. O homem não tem qualquer controle sobre ela.
} 
o faça por meio das transformações que sofre ao longo da trama, Gay acaba descendo aos recessos dessa lei, conquanto a saída torna-se impossível em sociedade. Resta a Gay degolar o sujeito e refestelar-se na condição de objeto - que, por sinal, lhe cabe -, em que sua personalidade se extingue, precipitando aquilo a que Lukács chama "qualidades psicológicas" próprias à função exercida.

Subjetivamente, numa economia mercantil desenvolvida, quando a atividade do homem se objetiva em relação a ele, torna-se uma mercadoria que é submetida à objetividade estranha aos homens, de leis sociais naturais, e deve executar seus movimentos de maneira tão independente dos homens como qualquer bem destinado à satisfação de necessidades que se tornou artigo de consumo. ${ }^{224}$

A morte, no enredo brechtiano, aparece no fim do processo de desumanização, consolidando-o de modo definitivo. Galy Gay é indubitavelmente o retrato desse rito avassalador, já que celebra o próprio funeral, sem ter sequer meios de retroceder. Já no enredo tolstoiano, a morte também implicará desumanização, com a diferença de que, como vamos verificar, ele concede ao personagem uma oportunidade de re-humanizarse mediante a proximidade do fim. Tolstói se revela, desse modo, um escritor pró-vida. Ao dizer que "um homem é um homem", Brecht ainda considera aquela criatura postiça em que se transformou Galy Gay, em fuga incansável de si mesmo, homem - uma vez que apto a desenvolver seus papeis sociais -, ainda que um sujeito incurável. Trata-se de uma crítica à sociedade desprovida de uma solução positiva; ao passo que Tolstói, ao diagnosticar o problema, nos oferece também o antídoto.

Bezerra enxerga a mesma problemática em $A$ morte de Iván Ilitch. Na trilha de Lukács, ele define alienação à luz de Marx como uma "força autônoma que exerce sobre o indivíduo um domínio (...) hostil a seus desígnios humanos naturais, e sob seu efeito o homem passa de sujeito ativo a objeto do processo social" ${ }^{225}$. Nessa jornada do indivíduo rumo à desumanização, a qual Galy Gay assume sem maiores dramas, e Iván Ilitch, por seu lado, reproduz inconscientemente desde que herdou do pai - não a tonalidade da pele ou a cor dos olhos, mas a função -, a personagem de Tolstói depara com a divisão do trabalho e, por conseguinte, o trabalho abstrato. Tolstói deixa muito claro que, na arrancada de Iván Ilitch rumo ao cume da hierarquia burocrática, quando

\footnotetext{
224 LUKÁCS, Georg. História e Consciência de Classe. São Paulo: Martins Fontes, 2003. p. 200

${ }^{225}$ BEZERRA, Paulo. Op. cit. p. 4
} 
se efetiva de forma mais acirrada a divisão social do trabalho e interrompe-se a relação do trabalhador com o produto acabado (daí o termo trabalho abstrato), mais alheio Iván se torna em relação a si mesmo e a todos os atributos que o caracterizam como ser humano.

Ivan Ilitch, graças a essa troca de pessoas, ganhou inesperadamente, no seu antigo ministério, a nomeação para um cargo dois níveis acima do dos seus companheiros. (...) Todo o ressentimento em relação aos seus antigos desafetos e a todo o ministério desvaneceu-se, e Iván Ilitch estava totalmente feliz.

(...) Iván Ilitch contara (...) como todos os seus inimigos tinham sido humilhados, e como agora se desfaziam em lisonjas diante dele, como o invejavam pelo posto, e, em especial, como era amado em Petersburgo.

(...) E agora que tudo se resolvera tão bem, e que ele e a mulher concordavam quanto às metas e, além disso, pouco viviam juntos ${ }^{226}$, eles se entendiam tão amigavelmente como não acontecia desde os primeiros anos da vida de casados. ${ }^{227}$

Enquanto Prascóvia Fiodoróvna está apaixonada, Iván se casa apenas porque lhe soa adequado, não ferindo a diretiva que estabelecera para si próprio segundo a qual a vida deve ser tranqüila, agradável, alegre, leve, sempre decente e aprovada pela sociedade. Bezerra aponta que, em sua vida conjugal, qualquer possível elemento de afeto é substituído pelos ornamentos da casa, pelos relevos da mobília, pelas quinquilharias decorativas, pelo fetiche - decorrente da idolatria do consumidor pelo produto. Ele perde três filhos (experiência bastante conhecida por Tolstói) e ignora solenemente tal contingência (pois o valor dessas perdas não pode ser calculado), sendo o ano mais "penoso",228 de sua vida, na verdade, aquele em que seus vencimentos ficam aquém de suas despesas e, o que é ainda mais tenebroso, as pessoas da alta sociedade o esquecem. Compreensível: em seu coração trafegam apenas os vícios de uma peça da geringonça social, e é sobre esse órgão flácido que Iván comodamente se alegra: no que ele julga ser melhor para sua ascensão, opera a diástole; na ruína de todos os outros, ribomba a sístole. "Esse panorama" - Russell comenta - "em que o nascimento e a

\footnotetext{
${ }^{226}$ Grifos meus.

227 TOLSTÓI, Lev. A morte de Iván Ilitch e outras histórias. Tradução do russo: Tatiana Belinky. Barueri: Editora Manole, 2011. p. 44

228 Ibidem. p. 41
} 
morte dos filhos são vistos mais como marcas do passar do tempo do que como importantes eventos de uma vida individual, reduz tudo ao que tem sido chamado de "uma forma de trivialidade indiferenciada",229.

O fato de Iván julgar-se poderoso, sentindo que todos agora estão em suas mãos, leva, nas palavras de Bezerra, "ao extremo sua desumanização"230.

Trata-se da internalização da autoridade social, das normas e formalidades do sistema na consciência e também no inconsciente de Iván Ilitch, (...) da transformação do amador na coisa amada pela internalização do eu de Iván Ilitch no próprio sistema jurídico burocrático, na diluição total do homem na função $(. . .)^{231}$

Esse é o fim do processo de desumanização (ou reificação) de Iván Ilitch e, portanto, sua morte em vida, um pouco mais sutil e menos palpável que a desventura de Galy Gay, que simula sua morte e muda de nome, de identidade. A alma de Iván é cooptada pela burocracia e o "homem" desaparece a perder de vista seja qual for a esfera da vida. Neste caso, um homem não é mais um homem.

\subsubsection{Quando a morte é a vida}

Certo dia, enquanto está às voltas com mais uma fina iguaria doméstica, Iván tropeça e se machuca. Tolstói narra o evento:

(...) Estava tão envolvido nisso que, muitas vezes, ele mesmo fazia mudanças: empurrava os móveis e trocava cortinados. Certa vez, ao subir na escadinha, para mostrar ao tapeceiro obtuso como queria o drapeado, falseou o pé e caiu; mas, como homem ágil e forte, segurou-se e apenas bateu de lado na maçaneta da esquadria. ${ }^{232}$

\footnotetext{
${ }^{229}$ RUSSEL, Robert. Op.cit. p. 634

${ }^{230}$ BEZERRA, Paulo. Op. cit. p. 7

${ }^{231}$ Ibidem. p. 7

232 TOLSTÓI, Lev. A morte de Iván Ilitch e outras histórias. Tradução do russo: Tatiana Belinky. Barueri: Editora Manole, 2011. p. 46
} 
Segundo Irving Halperin, o simbolismo da queda de Iván é simples: "ele cai do pináculo de seu orgulho e vaidade"233. Mas o autor, de início, não dá valor ao acidente, e este parece ser narrado apenas para mostrar, de outra forma, a euforia e disposição do Iván Ilitch (coisa) diante das outras coisas com as quais se relaciona. No capítulo IV, Iván começa a sentir alguns sintomas, ainda precários, que darão início ao processo em que o trem de sua vida se tornará arredio ao trilho a ele imposto e, por fim, irá descarrilar. Temira Pachmuss (1961) relata que, ao ser afetado pela "civilização", Iván Ilitch é impedido de entrar em contato com sua solidão e, nesse sentido, escapa da vida real. "A base de seu relacionamento com a natureza era corrupta; no entanto, ainda que capaz de escapar da vida real, ele não poderia escapar da morte"234. A morte, aqui, está intrinsecamente ligada à realidade. A ameaça de morrer, o sofrimento que emanará dessa certeza, fará que Iván recupere o senso de realidade por completo. A morte, portanto, para Tolstói, é um vínculo que se estabelece com a vida real, imune a contos de fadas como aquele que envolvia o personagem.

Em Anna Kariênina, por exemplo, a ligação que Tolstói faz entre morte e realidade se dá de forma sucessiva, sendo a morte não só uma forma de despertar para vida real, mas o prenúncio da realidade. Na história, um trem, ao recuar na estação onde Anna e Vrónski se vêem pela primeira vez, entrecruzando olhares enfeitiçados, esmaga um vigia. "É um mau presságio" 235 - diria Anna estremecida da cabeça aos pés. O acontecimento da morte abala a "vida aparente" que, na nobreza retratada por Tolstói, se consagra como a única vida permitida. Há um "clima" envolvente, precedente à tragédia, que ali prevalece. Pulverizado nos valores, hábitos, aquisições e enfatizado na sofisticação dos modos e educação esmerada, é como se tais embustes falassem por si próprios, guardando uma importância tácita e incontestável tanto maior a superficialidade, encerrando os mais elevados modelos de vida urbana, cujos parâmetros, por sinal, são reconhecidos no sotaque e fleuma de uma nobilíssima casta. Uma redoma muito parecida, não por acaso, com aquela da qual Iván Ilitch era prisioneiro.

Em um momento posterior, Vrónski, ao participar de uma corrida de cavalos, distrai-se durante o percurso e desaba junto com sua égua, que fere gravemente a

\footnotetext{
${ }^{233}$ HALPERIN, Irving. Op. cit. p. 336

234 PACHMUSS, Temira. Op. cit. p. 77.

235 TOLSTÓı, Liev. Anna Kariênina. Tradução do russo: Rubens Figueiredo. São Paulo: Cosac Naify, 2005. p. 77
} 
coluna $^{236}$ e tem sua morte selada pelo próprio montador. Ele desfere no animal um tiro de pistola. O "real", mais uma vez, pavoneia-se. Alheio à atmosfera romântica, ao incompatível delírio do casal frente ao way of life reinante, ele se insurge espatifando sonhos e demonstrando a impossibilidade absoluta deles. Zygmunt Bauman, "o teórico da modernidade", dá o tom:

Como observou Arthur Schopenhauer, a "realidade" é criada pelo ato de querer; é a teimosa indiferença do mundo em relação à minha intenção, a relutância do mundo em se submeter à minha vontade, que resulta na percepção do mundo como "real", constrangedor, limitante e desobediente. $^{237}$

A vontade de Iván, portanto, que a princípio é permanecer no universo do conto de fadas a qualquer custo, debate-se com um mundo em que as doenças, inclusive as enfermidades fatais, existem; e a realidade, para ele, por meio, inicialmente, de incômodos físicos, dores, e, a seguir, em função do comportamento dos médicos diante de sua desgraça, começa, pouco a pouco, a retirar o véu. A presença da realidade é tão incisiva por meio da morte, que ele, a despeito de inúmeras tentativas, não consegue fugir por muito tempo de seu contágio insidioso.

É a pragmática Prascóvia que, descontente com seu comportamento irritadiço, sugere que o marido vá consultar-se com um médico. "Ele foi." - narra Tolstói - "Tudo se deu como ele esperava; tudo aconteceu como sempre (...)"238. Contudo, é justamente nesse ponto que Iván Ilitch percebe-se, pelo menos, outro. O modo empolado e imperativo do doutor - ele já podia reconhecer - era como o dele em sua toga de juiz. Só que, perversamente, ele agora era o réu - o paciente. Era ele que estava nas mãos de um sujeito que, enfurnado em um monte de "pedágios", não iria "chegar" para esclarecer sua principal dúvida: "se a sua situação era perigosa ou não"239, se ele era culpado ou inocente, livrando-o de certa angústia. Para Halperin, os médicos parecem

\footnotetext{
${ }^{236}$ Em Anna Kariênina, é interessante notar a simbologia utilizada por Tolstói. No primeiro caso, na estação, com o recuo do trem, o corpo do vigia é mutilado. "Dizem que foi cortado em dois" - anuncia um cavalheiro. No segundo caso, a coluna da égua de Vrónski é partida ao meio, daí a impossibilidade de curá-la. Essas mortes que dividem tanto o homem quanto a égua em dois lados, certamente aludem ao relacionamento de Anna e Vrónski, que está condenado à separação física na vida real. TOLSTÓı, Liev. Anna Kariênina. Tradução do russo: Rubens Figueiredo. São Paulo: Cosac Naify, 2005. p. 77

${ }^{237}$ BAUMAN, Zigmunt. Modernidade Líquida. Rio de Janeiro: Zahar, 2001. p. 24

${ }^{238}$ TOLSTÓI, Lev. A morte de Iván Ilitch e outras histórias. Tradução do russo: Tatiana Belinky. Barueri: Editora Manole, 2011. p. 54

${ }^{239}$ Ibidem. p. 55
} 
estar bastante seguros da periculosidade do diagnóstico de Iván, mas temem comprometer-se em face de um veredicto.

A vida de Iván Ilitch, afinal, como atesta Tolstói, não importava. Muito mais interessante - e afeito ao conto de fadas, cabe lembrar - seria especular acerca da doença que o acometia. As hipóteses, que jamais evadem essa condição de hipótese, vão bem a calhar. Uma moléstia chamada "rim flutuante" sugere um órgão separado do corpo, à solta na atmosfera, à deriva em um mar de hemácias, como Iván estava dissociado do mundo real. Já um apêndice inflamado relativiza a inutilidade do apêndice que, nesse caso, serve para matar - imagem que também dialoga com o universo de Iván Ilitch, que, embora não participe da vida real, entra em contato com ela diante da possibilidade da morte. Ele, portanto, como seu apêndice, que não servia para nada de real, serve agora para a morte.

Ao analisar os tratamentos dispensados pelos médicos a Iván Ilitch e, igualmente, pela personagem aos réus e usuários da justiça, Bezerra faz uma declaração incisiva: "a cultura do culto exagerado das formalidades jurídico-burocráticas e das formalidades médicas, com o conseqüente desprezo pelo ser humano e suas ansiedades, é uma cultura da morte, um sistema de morte" ${ }^{, 40}$. E, nesse viés, acrescentaríamos: o sistema mercadológico, de que todas essas instituições derivam, seria, por si só, um sistema de morte. É esse o discurso que parece grunhir pelas entrelinhas de Tolstói.

Depois da consulta, Iván conclui que está mal e que "para o doutor, e quiçá para todos os outros, tanto fazia que ele, Iván Ilitch, estivesse mal"241. Por mais que ele tente refugiar-se da verdade, tomando medicamentos e, depois, fazendo de conta que os males que o afligem vão passar, a angústia cresce à medida que a realidade, como o sol ao alvorecer, desponta. Por essa altura, a personagem começa a necessitar da ajuda do outro da forma que jamais havia concebido. Iván, como Tolstói descreve em Uma confissão, postara-se por anos na posição do indivíduo - pelo autor tipificado em uma lista de três outros - que não cogita a existência da morte e ignora o futuro.

Nenhum artifício do conto de fadas, antes tão útil a um sem-número de fins para Iván Ilitch, como o jogo de cartas ou os bibelôs da casa, consegue já salvá-lo das vorazes dores da enfermidade - ou seja, eles deixam de surtir efeito no diâmetro dominado pela morte. Alguma coisa nele insiste em não ser mais "coisa calculável"

\footnotetext{
${ }^{240}$ BEZERRA, Paulo. Op. cit. p. 13

241 TOLSTÓI, Lev. A morte de Iván Ilitch e outras histórias. Tradução do russo: Tatiana Belinky. Barueri: Editora Manole, 2011. p. 55
} 
(aqui também no sentido de manipulável, certa, segura, precisa), e isso destrói aos poucos seus nervos. De absoluto - é como se Tolstói proferisse, fiando-se em sua conversão -, só Deus. Em certa medida, talvez um tanto rudimentar, Iván passa por um processo semelhante ao do próprio Tolstói.

Quando os amigos chegam para uma partida de whist, tudo aquilo que um dia lhe parecera perfeito, como um slam, soa-lhe absurdo agora diante do inominável mal-estar que freme sua ilharga. Segundo Russel, tal passagem não se trata de uma mera cena, mas de um "incidente representativo deliberadamente escolhido para marcar um ponto" 242 - o que nos faz rememorar Bakhtin quando afirma que, ao optar por um discurso monológico, Tolstói dispõe idéias nos lábios das personagens e distribui verdades impessoais.

No trabalho, mais uma vez Iván Ilitch se reconhece: dessa vez em Schwarz; um janota não muito diferente daquilo que ele fora dez anos antes, imerso em irritante vitalidade comme Il faut ${ }^{243}$. Na verdade, aponta Russel, “O abominável Schwarz, que alguns críticos tem comparado a Mefistófeles ${ }^{244}$, é uma ampla projeção do próprio Iván Ilitch e dos outros de seu círculo social” ${ }^{, 245}$.

"Era impossível iludir-se" - registra Tolstói - "algo terrível, novo, e tão significativo como nada mais significativo ocorrera em sua vida acontecia agora com Iván Ilitch. E só ele sabia disso"246. Iván testemunha toda a máquina da qual fora entusiasta devotado voltar-se abruptamente em sua direção. Devastado pela realidade, pela morte, ou pela vida que lhe feria os olhos em virtude do excesso de luz, ele recorre à família - instituição cujos cuidados nunca requisitara antes, mas que agora, estranhamente, julga conveniente procurar. Ali, entretanto, à semelhança do consultório médico, ninguém entende ou deseja entender os tormentos sofridos por Iván, visto que, graças também a seus esforços, se converteram naquilo que ele um dia fora: uma coisa. Paulo Bezerra emenda:

A esse sistema acrescenta-se o tipo de família burguesa que Iván Ilitch construiu à sua imagem e semelhança, tão indiferente às angústias que o martirizavam que a mulher, além de culpá-lo pela doença (...), só

\footnotetext{
${ }^{242}$ RUSSEL, Robert. Op. cit. p. 634

${ }^{243}$ Como manda o figurino.

${ }^{244}$ Mefistófeles representa, no folclore alemão, a figura do diabo, do demônio, de Lúcifer.

${ }^{245}$ RUSSEL, Robert. Op. cit. p. 632

246 Ibidem. p. 60
} 
lamenta sua morte porque esta a deixará sem os vencimentos do marido. $^{247}$

Como se não bastasse, nesse contexto - adverte Bezerra - a presença moribunda do adoentado é equiparada pelos membros de sua família aos problemas e acontecimentos usuais da casa, como o cardápio para o jantar, as visitas recebidas, o estilo das cortinas ou uma cadeira quebrada. Nessa "via crúcis" rumo ao calvário, há uma vantagem: Iván, de súbito, começa a pensar, a articular idéias, a fazer conjecturas e tem um momento-chave de descoberta. O narrador escreve: "O apêndice, o rim - disse para si mesmo. - Não é do apêndice, nem do rim, que se trata. Trata-se da vida... e da morte"248 249. É uma virada. As "coisas" começam a apontar, finalmente, para problemas reais, de valor inestimável. Interessante observar, no entanto, que nesse estágio Iván Ilitch ainda supõe que tenha realmente "vivido". E que nessa sua suposta vida "Havia luz e agora são trevas",250; quando é justamente o contrário: agora o Sol erguia-se quase a pino e a luminosidade predominava.

Observe-se que no final do quarto capítulo, o narrador menciona que a consciência da doença torna Iván Ilitch um homem solitário: "E ser obrigado a viver assim, à beira do perecer, sozinho, sem um único ser humano que pudesse compreendêlo e lamentá-lo"251 252. Não há outro ser humano, é o que ele diz. No final do sexto capítulo, no entanto, dessa vez consciente da morte, tendo compreendido algo tangente a seu estado, ele não está já sozinho - há alguém com Iván: "E ele entrava no gabinete, deitava-se e ficava novamente a sós com ela. Olho no olho com ela, e nada a fazer com ela. Somente fitá-la e sentir-se gelar." ${ }^{253}$ A morte é algo tão alheio ao desumano mundo que o cerca, onde todos são "animais" que não a reconhecem, como ele próprio urrara em desespero, que ela repele tudo o mais e converge suas forças para um só lugar, sendo, por Iván, personificada: a morte é humana. Sua presença não está difusa pelas desavenças e pelos penduricalhos que fazem que ele a ignore por alguns segundos, mas disposta de maneira concentrada, condensada. Para Iván, de tão estranho ao seu "antigo" meio, trata-se de algo quase palpável. Não é à toa que Bakhtin declara que a

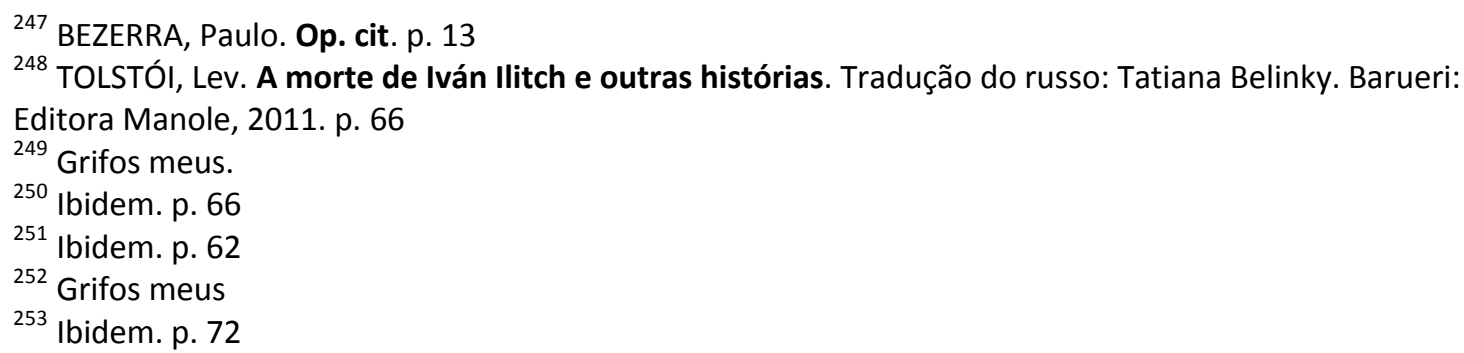


morte, em Tolstói, se dá na consciência da pessoa que está em vias de morrer quase como um fato dessa consciência.

No momento que poderia ser o mais catastrófico e humilhante para Iván Ilitch, quando passa a depender de outra pessoa para limpar suas evacuações, surge o mujique Guerássim. A partir daí, ele nem está sozinho, nem está a sós com ela, mas está com um ser humano. Percebemos, nesses trechos, a ocorrência do paralelismo. Para Tolstói, nas palavras de Aleksandra Tolstói, "os camponeses eram as pessoas reais - aquelas que trabalhavam com suas mãos e alimentavam o mundo com o que elas produziam; elas estavam próximas à natureza e, portanto, mais próximas de Deus." ${ }^{254}$ Guerássim vem referendar esse pensamento como o camponês que chega à cidade e não perde as raízes que fizeram dele um verdadeiro ser humano, com quem Iván agora pode dialogar:

- Isto decerto te é desagradável, eu acho. Desculpa-me. Eu não posso.

- Mas o que está dizendo, senhor? Os olhos de Guerássim brilharam, e ele mostrou seus jovens e alvos dentes num sorriso. - Que é que tem isso? $O$ seu caso é de doença.

Guerássim, homem do povo, não dá margem a possíveis entraves que possam obstacularizar o acesso ao ventre de sua alma. Nesse âmbito, também se comunica profundamente com o ser humano que naquele hiato de angústia pré-morte é despertado em Iván. De um lado, vemos a opressão psicológica por tanto tempo causada pela civilização e, de outro, a liberdade compartilhada por indivíduos que, dadas as condições como vivem (e resistem), estão imunes à torpe lógica que pontua um universo irreal.

Dada a sua humanidade, Guerássim consegue fazer aquilo que médico nenhum conseguira: amenizar as dores físicas de Iván e, por conseguinte, as dores morais. Ao permitir sem reservas que Iván apóie os pés em seus ombros, ele se recusa a compactuar da mentira que todos encenam ao redor do patrão, uma vez que não admitem aquilo que já tamborilava no coração de Iván: ele morreria dentro em pouco. Naquele horizonte, o moribundo era perversamente excluído, e a morte, por seu turno, não era algo natural. De natural e real, no entanto, havia Guerássim. “Guerássim - só ele - era o único que

\footnotetext{
${ }^{254}$ TOLSTOY, Alexandra. Tolstoy and the Russian Peasant. Tradução minha. Russian Review, Vol 19, no 2. Blackwell Publishing, 1960. Disponível em: <http://www.jstor.org.stable/126737>. Acesso: 11/08/2011. p. 151
} 
compreendia essa situação e se condoía dele. E por isso Iván Ilitch só se sentia bem na companhia de Guerássim. ${ }^{, 255}$ À medida que as pessoas do séquito usual de Iván se acercam das mais grotescas condutas para não vê-lo, Guerássim facilmente se aproxima, como o mais simples a ser feito.

- Todos vamos morrer. Por que, então, não fazer um esforço? disse ele, expressando com isso que não sentia o peso daquele trabalho, justamente porque o fazia por um moribundo e tinha esperança de que, na sua hora, alguém fizesse o mesmo serviço por ele. ${ }^{256}$

Guerássim é um indivíduo in natura, espalha "em volta de si um agradável odor de alcatrão das botas grossas e do frescor do ar hibernal" 257 , usa avental de cânhamo e camisa limpa de chita, é asseado, vigoroso, corta lenha, labora junto à natureza, tem as mangas arregaçadas e, no compasso de sua bondade, sorri: por isso, seus dentes alvos estão sempre à mostra. Tolstói pinta seu ideal de camponês e associa a natureza à vida humana. Por outro lado, toda a existência de Iván Ilitch acontecera em espaços fechados, "em casa ou escritórios de uma classe particular"258. Russell registra: "Iván Ilitch, sua família e colegas não têm nenhum contato com o mundo natural, sendo os fenômenos naturais - as árvores, a grama e até o clima - irrelevantes para as motivações sociais de suas vidas" ${ }^{259}$. A vida real também chega a Iván Ilitch por meio do contato com a terra que ele tem por intermédio de Guerássim. Em certa medida, o mujique traz ar fresco a seu senhor, garantindo-lhe uma sobrevida, reanimando seu espírito morto.

Quando Iván recapitula momentos de sua vida, tudo o que lhe soava antes tão alegre, repentinamente, parece ter absorvido o hálito da morte. Sobrevém-lhe à mente as primeiras lembranças da infância: "Ali, na infância, havia algo de verdadeiramente agradável, com o que se poderia viver, se isso voltasse" ${ }^{, 260}$. Não é à toa que seu filho mais novo, Vássia, é o único da família a compadecer-se do pai ${ }^{261}$. O narrador faz, no

\footnotetext{
${ }^{255}$ TOLSTÓI, Lev. A morte de Iván Ilitch e outras histórias. Tradução do russo: Tatiana Belinky. Barueri: Editora Manole, 2011. p. 77

256 Ibidem. p. 78

${ }^{257}$ Ibidem. p. 74

${ }^{258}$ RUSSEL, Robert. Op. cit. p. 635

259 Ibidem. p. 635

${ }^{260}$ TOLSTÓI, Lev. A morte de Iván Ilitch e outras histórias. Tradução do russo: Tatiana Belinky. Barueri: Editora Manole, 2011. p. 91

261 "Na concepção de Tolstói, a infância é a era de ouro na qual, se alguém pertence à certa classe, é desviado pela sociedade. (...)" É por isso que Vássia, "ainda que capaz de sentir amor e pena, está a ponto de ser defletido pela sociedade, ao posso que sua irmã já foi”. RUSSEL, Robert. Op. cit. p. 639
} 
entanto, um aparte, dizendo que "aquele ente que vivera algo agradável já não existia"262 $^{\text {. Wasiolek }}{ }^{263}$ reconhece que não há coincidência nenhuma no fato de a dor que tortura seu corpo deflagrar em sua mente memórias da infância de natureza sensível e, sobretudo, pessoal. "É por meio das reminiscências da infância que Iván Ilitch restabelece sua visão única do mundo"264. Há um despertar físico também, que ocorre no embalo das dolorosas lembranças do marroquim, dos brinquedos ou do sabor das "ameixas francesas, enrugadas, cruas e secas"265. A decepção, entretanto, de saber que sua vida deslizava como uma pedra rumo ao sem sentido do sofrimento, atordoava-o, somando-se à angústia do mistério relativo à vida e à morte. Por que, afinal, tinha de sofrer daquele jeito? Para que havia de morrer se tinha vivido nos limites da "legalidade, correção e decoro" "266 ? Até que lhe salta à mente: "E se de fato toda a minha vida, a vida consciente, não foi como devia ter sido?"267. Ele percebe, de rompante, que sua vida fora um encadeamento banal de sabotagens, um arroubo de "trivialidade indiferenciada", "um enorme equívoco" 268 - aponta o narrador - "que encobria tanto a vida como a morte". ${ }^{269}$ Essa era a mais terrível verdade para Iván, mas ainda não se tratava da liberdade - ou, em outras palavras, da possibilidade para a morte, no sentido que Blanchot deu à expressão.

Nos estágios terminais da doença, quando Iván Ilitch começa a se esgoelar semiconsciente, o narrador descreve como o personagem se debate em um saco negro, "no qual o enfiava uma força invisível e invencível" ${ }^{270}$. Provavelmente, ele se desesperasse pela recusa em aceitar que era aquela a única realidade a ele reservada. Russel assinala, entretanto, a sofisticada e bela metáfora contida por detrás dessa imagem, que, na verdade, estaria fazendo referência às dores do parto. No processo de morte, Iván regressa a situações infantis, solicitando ajuda para defecar, por exemplo, o que culmina "na repetição da experiência do nascimento",271. A morte de Iván Ilitch, com efeito,

\footnotetext{
${ }^{262}$ TOLSTÓI, Lev. A morte de Iván Ilitch e outras histórias. Tradução do russo: Tatiana Belinky. Barueri: Editora Manole, 2011. p. 91

${ }^{263}$ Edward Wasiolek, professor de Literatura Comparada e Eslava da Fundação Avalon, é autor do livro Tolstoy's Major Fiction, no qual analisa as principais obras do autor russo.

${ }^{264}$ RUSSEL, Robert. Op. cit. p. 639

${ }^{265}$ TOLSTÓI, Lev. A morte de Iván Ilitch e outras histórias. Tradução do russo: Tatiana Belinky. Barueri: Editora Manole, 2011.p. 95

${ }^{266}$ Ibidem. p. 96

267 Ibidem. p. 98

268 Ibidem. p. 99

269 Ibidem. p. 99

${ }^{270}$ Ibidem. p. 101

${ }^{271}$ RUSSEL, Robert. Op. cit. p. 636
} 
marca seu renascimento. O que ainda o enreda àquela vida e o faz comportar-se de maneira demasiado histérica, rebelando-se contra o fim, é o fato de sua "sagração" como ser humano não ter sido finalizada. A morte inspira-lhe horror, como inspira em todos aqueles que o cercam, menos em Guerássim. Para Iván Ilitch romper seu elo com a mentira, ele precisa encarar o evento da morte com naturalidade. Paulo Bezerra acrescenta:

Ainda lhe falta uma coisa: superar a concepção de morte banalizada em seu meio, em sua cultura, onde ela é reduzida a um desagradável acaso, a algo indecente que só provoca dor e pavor. Desde que tomou consciência da gravidade da doença começou sua luta contra todos ao redor pelo direito à morte, mas só depois de superar aquela concepção idiota e concluir que a morte é a conseqüência mais natural do viver (...) é que conquista sua própria concepção de morte e consegue morrer. $^{272}$

À essa solução, entretanto, Iván Ilitch só chega quando está prestes a morrer, encenando um grand finale respaldado sobre um quê de miraculoso e epifânico. Tolstói registraria, em 1898, que "No instante da passagem [da vida à morte] fica evidente, ou pelo menos se sente, a realidade mais presente" ${ }^{273}$. Na novela, Iván Ilitch, que já havia passado por várias etapas de entendimento da realidade, entra num processo de purificação, revelação, admiração ${ }^{274}$, ou iluminação ${ }^{275}$, no qual a morte, da maneira que seu círculo comme Il faut entende, deixa de existir. Por meio do amor, ele se une ao infinito que Tolstói menciona em Uma confissão, ele se torna Residente. "A morte de Iván Ilitch é uma história emblemática de crise e conversão"276 277 - aponta Gustafson, e acrescenta: "ela nos conta sobre a descoberta da vida em face da morte. Trata-se da imagem ficcional da "suspensão da vida"”,278 da qual Tolstói parte em Uma confissão.

\footnotetext{
${ }^{272}$ BEZERRA, Paulo. Op. cit. p. 14

273 TOLSTÓI apud STEINER, George. Op. cit. p. 187

274 "Esses instantes em que a luz da utopia penetra, por um momento, na obscuridade do sujeito, Bloch chama-os admiração". LÉVINAS apud HADDOCK-LOBO, Rafael. O Ser e a Morte. Anuário de Filosofia São João Del-Rei, no 10. São João Del-Rei, 2003.

${ }^{275}$ Outros personagens de Tolstói, como Nikolai Liévin, Anna Kariênina ou o príncipe Andriéi de Guerra e $P a z$, a um passo da morte, também se defrontam com momentos de iluminação semelhantes ao de Iván Ilitch. A experiência do amor vinculada à iminência da morte é uma constante em Tolstói.

${ }^{276}$ GUSTAFSON, Richard F. Op.cit. p. 159

${ }^{277}$ Grifos meus

${ }^{278}$ Ibidem. p. 159
} 
Poucos dias antes de sua própria morte, o autor ditaria à sua filha Aleksandra: "Quanto mais o homem ama, mais real ele se torna." 279 E é disso que trata a novela: Iván passara por um rito do qual vai do desamor, que é a morte, para o amor, a vida. Para Tolstói, "O amor é a realidade última"280. Ser humano é ser capaz de amar, e o sentido da vida estaria repousado sobre essa sólida superfície. As fases da transformação da personagem, segundo Halperin, estão bastante claras no decorrer da história: do desespero Iván passa ao amor e, por último, à redenção. Sob essa perspectiva, os aspectos da metamorfose que, de acordo com Patterson, Tolstói enfrenta em Uma confissão não são muito diferentes: (1) o encontro com a morte, (2) o acesso de desespero, (3) a luta pela possibilidade e (4) o movimento de fé. Este último aspecto, no caso de Iván Ilitch, pode ser identificado como a redenção por meio da purificação. Há, nessa trilha, como houve em Tolstói, um "sair de si mesmo" e um "voltar-se para o outro". Nesse sentido, Tolstói deseja, por meio de sua "parábola”, levar uma verdade ao mundo, tornando a experiência particular do personagem uma experiência universal. A literatura estava, neste caso, a serviço do que o autor acreditava e condizente com o que ele se propusera.

Vale observar ainda que, no que toca aos camponeses, o benefício da iluminação é desconsiderado pelo autor, já que eles, distantes da civilização, sempre estiveram de posse do mais genuíno amor. Sendo, de antemão, puros, não há nada neles a purificar.

\subsection{Senhor e Servo}

Cerca de 10 anos após escrever A morte de Iván Ilitch, Tolstói, aos 66 anos, escreve, em 1894, Senhor e Servo. Destituída dos pesados suplícios por que passa Iván, que a tudo embebe de angústia pegajosa, essa novela possui um tom menos rancoroso, menos arquejante - à exceção das bufadas de Baio -, ainda que esbarre em questões semelhantes. Ler A Morte de Iván Ilitch, por mais edificante que seja, é como despertar de um pesadelo. Ler Senhor e Servo, porém, é como, aliviado pelos tropeços da estrada, guarnecida, no entanto, de uma natureza exuberante, chegar a casa e descansar. A morte, neste caso, serve não só para a transformação do personagem principal, Vassíli Andrêitch Brekhunóv, mas para salvar uma outra vida, a do camponês Nikita. "Essa

\footnotetext{
${ }^{279}$ TOLSTÓI apud HALPERIN, Irving. Op. cit. p. 338

${ }^{280}$ PACHMUSS, Temira. Op. cit. p. 82
} 
tardia narrativa é uma emblemática jornada de descoberta e uma parábola sobre o caminho para o amor"281 - ressalta Gustafson.

\subsubsection{Relações}

Vassíli Andrêich era o referido senhor de uma aldeia onde também exercia a função de curador da Igreja. Ambicioso, "no dia seguinte ao S. Nicolau de inverno"282 conta o narrador -, ele estava ávido para fazer uma viagem a fim de fechar negócio referente à compra de um bosque em Goriátchkino. Sua ânsia de chegar àquele lugar e adquirir a terra antes de outros possíveis interessados era enorme, e ele não podia mais esperar. Conseguiu juntar três mil rublos para dar como adiantamento pelo bosque, e Nikita, o servo, foi atrelar o cavalo.

Nikita era um mujique de 50 anos de idade que, recentemente, ao contrário dos outros serviçais, após uma bebedeira, fizera a promessa de não beber e a cumpria. $\mathrm{O}$ mujique nutria "uma índole bondosa e afável", honestidade e amor pelos animais. Todos na região gostavam dele, ainda que para Vassíli Andrêitch a maior satisfação de tê-lo por perto fosse seu preço barato.

Vassili Andrêitch pagava a Nikita não oitenta rublos, que era o que valia um trabalhador como ele, mas apenas uns quarenta, que, sem fazer as contas, entregava-lhe aos poucos, e mesmo assim, não em dinheiro, mas em mercadorias, a preços altos de seu próprio armazém. $^{283}$

Boris Schnaiderman aponta que há, em Tolstói, uma referência à Dialética do Senhor e do Escravo, de Hegel. Tolstói estaria seguindo a concepção hegeliana da dependência do senhor em relação ao escravo, embora sem colocá-la em termos da mesma dialética. "O escravo é o mais forte, o mais sábio e, numa situação difícil tornase capaz de se sacrificar pelo senhor, mas este, que é o mais fraco, o mais ganancioso e

\footnotetext{
${ }^{281}$ GUSTAFSON, Richard F. Op.cit. p. 197

282 TOLSTÓI, Lev. A morte de Iván Ilitch e outras histórias. Tradução do russo: Tatiana Belinky. Barueri: Editora Manole, 2011. p. 107

283 Ibidem. p. 109
} 
mesquinho, acaba não resistindo à adversidade, pois não possui a tranqüilidade (...) do povo." 284

$\mathrm{Na}$ reflexão de Hegel, o senhor é uma consciência que se relaciona consigo mesma através de outra consciência. Essa outra consciência residiria no ser material do escravo, e é através deste que o senhor goza de sua vida. Disso decorre que, servindo-se do escravo como se ele fosse uma extensão de seu corpo com o fito de transformar a natureza, o senhor perde todo o contato com a natureza e passa a depender do escravo.

Como aponta o narrador, porém, "Vassíli Andrêitch acreditava sinceramente que beneficiava Nikita" ${ }^{285}$. Gustafson registra que Brekhunóv não tem dúvidas a respeito de sua virtude como senhor. Para um senhor comerciante - diz Gustafson - "o mundo que a ele pertence é a soma total de suas aquisições (...). O senhor é alguém que foi removido das relações humanas" ${ }^{286}$. E Nikita, por sua vez, apesar de saber perfeitamente que era enganado, fingia acreditar em seu senhor.

A mulher de Vassíli também via Nikita como uma espécie de extensão das vontades do marido e, preocupada com o mesmo, sugere que o servo o acompanhe na viagem. Mas, apesar de muito abusar do servo, Vassíli Andrêitch acredita que não precisa dos outros, sem a consciência nítida de que sem Nikita ele nem sequer pode atrelar o cavalo. Como fica claro no decorrer da história, ele vive do passado e para o futuro. Já Nikita vive no presente. Nikita não tem propriedades nem aspirações. Não pode viver do passado porque não tem um, como também não há nenhum futuro pelo qual ele deseje viver. "Ele está onde está, vive onde vive e faz o que faz"287. É um trabalhador que depende de suas ações presentes para sobreviver e para manter o equilíbrio da natureza a seu entorno, da qual os animais que tanto ama são parte essencial. Em Uma confissão, ao aproximar-se do campesinato, Tolstói percebe essa dimensão: a vida do povo é "aqui e agora", ao passo que ele geme a cada minuto ao cogitar o que lhe reserva o futuro: a morte. Schopenhauer credita esse comportamento direcionado ao futuro e de negação do presente à morte. Por não ter conhecimento verdadeiro da morte, o animal gozaria "imediatamente de todo o caráter imperecível da espécie, na medida em que só se conhece como infinito" ${ }^{288}$, como ente habitante do

\footnotetext{
${ }^{284}$ SCHNAIDERMAN, Boris. Op. cit. p. 28

285 TOLSTÓI, Lev. A morte de Iván Ilitch e outras histórias. Tradução do russo: Tatiana Belinky. Barueri: Editora Manole, 2011. p. 109

${ }^{286}$ GUSTAFSON, Richard F. Op.cit. p. 197

${ }^{287}$ Ibidem. p. 198

${ }^{288}$ SCHOPENHAUER, Arthur. Op. cit. p. 59
} 
agora. A razão seria responsável por ter concedido ao homem a certeza da morte e, nesse tráfego, a preocupação insensata com o futuro. Mais próximo da natureza, o mujique não se ocupa com a morte, à semelhança dos animais, ao passo que a vida mental de Brekhunóv consiste em "somar o passado e calcular o futuro"289. Que importa se seu filho é ou não amado? O principal é que ele seja "herdeiro" - palavra que expressa três idéias: morte, legado e futuro.

O narrador revela, em atos cotidianos, a ausência de alteridade em Vassíli, que, ao não se relacionar com o presente, não se relaciona com o humano. Quando ele sobe no trenó, por exemplo, ocupa "quase toda a traseira curva do veículo"290, enquanto Nikita acomoda-se na frente, do lado esquerdo e "com uma perna para fora"291.

\subsubsection{A jornada}

Vassíli e Nikita partem da aldeia chamada Kriésty (кресты), cujo significado em russo é "Cruzes", rumo a Goriátchkino. O ambiente da estrada, entretanto, não é tão afável quanto eles imaginavam, pois a neve, que recrudesce conforme eles avançam, começa a encobrir os sinais de localização. Vassíli se perde por não conseguir já visualizar os marcos. Nikita, assim, tem de descer do trenó para reencontrar a trilha encoberta, descobrindo que eles estão sobre o campo da plantação de Zakhárov. Finalmente, seguindo as orientações de Nikita, Vassíli e o servo chegam a algum lugar: a aldeia de Gríchkino.

Como "De Gríchkino até Goriátchkino a distância era apenas de umas cinco verstás" 292 - informa o narrador -, Vassíli retoma seu otimismo. Na aldeia, eles esbarram com Issái, um mujique famoso por roubar cavalos. Este explica a direção a Vassíli, enquanto ele enfatiza seu desejo de não pernoitar na aldeia, o que seria o mais indicado em face das condições do tempo, e Nikita, um homem da natureza como Issái, não deixa de perceber isso.

Eles prosseguem na jornada: Vassíli Andrêitch, Nikita e Baio, o cavalo. Nesse caminho, o trio alcança companheiros de estrada em um trenó com três mujiques e uma

\footnotetext{
${ }^{289}$ GUSTAFSON, Richard F. Op.cit. p. 198

290 TOLSTÓI, Lev. A morte de Iván Ilitch e outras histórias. Tradução do russo: Tatiana Belinky. Barueri:

Editora Manole, 2011. p. 116

291 Ibidem. p. 116

292 Ibidem. p. 125
} 
mulher. O narrador assinala: "Um dos homens açoitava com um vara o lombo coberto de neve do seu cavalinho"293. Nikita, amuado, os chama de brutos pelo que fazem ao animal, enquanto Vassíli se sente reanimado, não tardando em castigar, por seu lado, Baio. Eles se perdem de novo, contudo. E, de novo, Nikita desce à cata de sinais na estrada, mas nada encontra. "De novo é uma palavra-chave na história"294 - comenta Gustafson. Quando é assim, o mujique deixa a natureza agir: "Se deixares o cavalo andar sozinho, ele leva a gente. Dá-me as rédeas." 295 Quando é assim, na verdade, a autoridade passa do senhor ao servo - o qual serve à natureza e dela se serve - e, nesse rastro, do servo à natureza. Eles voltam à estrada no embalo de Baio e, de súbito, percebem estar novamente em Gríchkino. A atmosfera circundante dava seu recado: “fiquem aqui". Vassíli resolve pedir ajuda em uma casa da aldeia.

A tal casa tem um quê de paraíso, dada a vodka servida, o chá oferecido em abundância e saído fervilhante do samovar, o aconchego e a simpatia da família. Os anfitriões, aliás, apelam para que Vassíli e Nikita ali pernoitem, já que com a neve, o vento e a escuridão a estrada era demasiado perigosa. Vassíli, entretanto, respondia: "Não dá, mano, são os negócios! (...) Se eu perder uma hora, não a recupero em um ano - acrescentou, lembrando-se do bosque e dos comerciantes que podiam arrebatar-lhe essa compra." 296 O futuro admoestava-o como um vozerio em sua mente. Enquanto isso, Nikita regenera-se na percepção do agora, completamente envolvido pelo chá que aquecia seu corpo enregelado. Contudo "não tinha a menor disposição para partir, mas se acostumara há muito tempo a não ter vontade própria e a servir os outros, de modo que ninguém reteve os viajantes.” Petrúchka, o mujique da casa, levá-los-ia até a um determinado ponto, e, depois, seria por conta deles.

\subsubsection{Da perdição à salvação}

À medida que percorrem o caminho indicado, e que deveria desembocar em uma floresta, eles mais uma vez se perdem. E, claro, Nikita desce do trenó, espezinhado pela intempérie, para deambular por ali. "Uma três vezes ele sumiu de vista"297 - adverte o

\footnotetext{
293 Ibidem. p. 127

294 GUSTAFSON, Richard F. Op.cit. p. 199

295 TOLSTÓI, Lev. A morte de Iván Ilitch e outras histórias. Tradução do russo: Tatiana Belinky. Barueri:

Editora Manole, 2011. p. 129

${ }^{296}$ Ibidem. p. 137

${ }^{297}$ Ibidem. p. 146
} 
narrador. Nesse ínterim, Nikita cai em um barranco e, a despeito de conseguir dele sair, o mujique não vê mais jeito de sair daquele lugar, uma vez que, caso se desloquem, o destino será o buraco. Quando o problema diz respeito ao presente, o Servo volta a ganhar a autoridade, e a Vassíli não resta alternativa, a não ser resmungar calado. Nikita pensa no bem comum - o do cavalo, o de Vassíli e, por último, o dele. E o Senhor, ainda com os olhos no futuro, acredita que vai morrer congelado se ali ficar, ao que Nikita responde: "E daí? O que vier, não dá pra recusar.,"298

Nikita demonstra um carinho especial pelo cavalo, cobrindo-o com um forro e, em seguida, aninha-se em uma cova na neve que cobre com palha, de modo que Vassíli, sozinho no trenó, começa a ter pensamentos repetidos.

Pensava sempre sobre a mesma coisa, sobre aquilo que constituía a única meta, o sentido, a alegria e o orgulho da sua vida: dinheiro. Quanto dinheiro já ganhara, e quanto ainda poderia ganhar; quanto dinheiro ganharam e possuem outras pessoas, suas conhecidas, e como ele, assim como elas, poderá ainda ganhar muito dinheiro. (...) Tinha esperança de ganhar, com esse bosque, de uma só vez, uns dez mil rublos. ${ }^{299}$

Vassíli rumina em torno do sonho de ser milionário, e a intensidade de sua emoção é proporcional à hostilidade da natureza ao seu redor, como se ele tivesse de fazer jus a tudo aquilo por que passava - afinal de contas, sua persistência, para ele, era admirável. Ora ele acredita que não devia ter ouvido Nikita, ora que o melhor teria sido mesmo ficar em Gríchkino ("mas como ele poderia prever?"), até que sua atividade mental se torna uma terrível mixórdia e, absorvido pela torrente de pensamentos, ele consegue adormecer. Ao despertar, entretanto, acredita que já é quase dia, mas não: a noite mal começara. "Pôs-se a calcular de novo os seus lucros (...) a vangloriar-se perante si mesmo", mas, como Iván Ilitch, diante da ameaça da morte, aqueles pensamentos não surtiriam mais qualquer efeito. A ameaça se delineia a princípio como um "medo sorrateiro" 300 e um arrependimento profundo por não ter permanecido em Gríchkino. À semelhança de Iván, que se dá conta que seu problema não se trata de rim ou apêndice, mas de vida ou morte, Vassíli diz consigo: "Deixa pra lá o tal bosque,

\footnotetext{
298 Ibidem. p. 149

299 Ibidem. p. 153

${ }^{300}$ Ibidem. p. 157
} 
tenho negócios suficientes sem ele, graças a Deus (...). Dizem que os ébrios é que morrem gelados (...). E eu bebi" ${ }^{301}$.

Até que o acesso de desespero, como uma fase de um processo que culminará na redenção, o acomete. Aos tropeços, ele monta em Baio e embrenha-se alucinado pelo breu. Para Vassíli, parar e esperar seria impossível. Era preciso manter-se em movimento, mesmo que este fosse circular, ou, a bem dizer, neurótico. "A fim de aplacar seu medo, Brekhunóv faz o que sempre fez: ele se ocupa em seguir adiante." salienta Gustafson.

Nesse ponto, Tolstói contrapõe as ações de Vassíli às de Nikita. E é notória a simbiose entre o servo e a natureza. Tal qual um tronco ou um galho de uma árvore, como examinaremos mais adiante em Três mortes, Nikita aceita a morte como um evento inerente à natureza da qual ele faz parte, cujo dom é transformar uma espécie de vida em outra e, assim, reinventar-se infinitamente - vislumbrando o perecer de uma perspectiva macro, como alguém que sobrevoa o planeta. Só o indivíduo egóico, nesse sentido, conheceria a palavra fim.

Ele, como todos aqueles que convivem com a natureza, era paciente e capaz de esperar calmamente durante horas e até dias, sem sentir inquietação ou irritação. Ouvira o patrão chamá-lo, mas não respondera porque não queria responder nem se mover. Embora ainda se sentisse aquecido (...), Nikita sabia que esse calor não duraria muito (...) A idéia de que poderia e, provavelmente, até deveria morrer nesta noite já lhe ocorrera, mas não lhe pareceu nem tão desagradável nem especialmente assustadora. ${ }^{302}$

Nikita sente que seu Senhor, na realidade, não é e jamais fora Vassíli, mas é o "Patrão maior, Aquele que o enviou para esta vida"303. Em Tolstói, a verdade se fortalece - e se torna mais óbvia - em função da proximidade da morte. Sabendo estar com Deus, Nikita, congelando, decide ir para o interior do trenó.

Enquanto isso, o círculo vicioso de Vassíli tem início. Coisas pretas começam a projetar-se à sua frente, e ele as segue atordoado e cego, arrebentando com o que o cavalo ainda tem de vida. Baio, porém, também já não lhe obedece, deixando-o só “no

\footnotetext{
301 Ibidem. p. 159

302 Ibidem. p. 162

${ }^{303}$ Ibidem. p. 162
} 
monte de neve" ${ }^{304}$. O pânico aumenta e os pensamentos se embolam. Agora, Vassíli não tem mais nada - e até seus servos, Baio e Nikita, o abandonaram. Seus negócios soam sem propósito. Ele percebe que a realidade o assunta: a nevasca, a escuridão, o medo. A morte, como vimos em A Morte de Iván Ilitch, permite que a vida real promova uma desforra: "Esta era uma neve real, a que lhe açoitava o rosto, e o cobria, e gelava a sua mão direita (...) e era um deserto real, este no qual ele agora se encontrava solitário, real como aquele artemisal, à espera da morte inevitável, iminente e sem sentido „305 306 . É uma tomada de consciência. Vassíli resolve seguir as pegadas do cavalo, e estas, como não podia deixar de ser, o levam de volta ao trenó e a Nikita.

Ao encontrar Nikita, este pressente a morte e lhe confidencia, pedindo perdão, o desejo de que o pouco que tem passe à mulher ou ao filho. É quando Vassíli, após remover a neve do trenó, deita-se em cima do servo "cobrindo-o não só com a sua peliça, mas com todo o seu corpo quente e afogueado." ${ }^{, 307} \mathrm{O}$ narrador conta que um estado de espírito jubiloso tomou a alma de Brekhunóv. E seu júbilo, naturalmente, vinha de dar a vida por outro ser humano, o que o levava a sentir sua humanidade plenamente.

Partindo de artigo de Richard A. Cohen, podemos fundamentar essa emoção que invade Brekhunóv ao morrer pelo outro, o que prenuncia seu encontro com Deus, em Emmanuel Lévinas. Em Ser e Tempo, Martin Heidegger descobre que a relação do ser humano com a morte é de suma importância para que aquele depare com seu "mais basilar, próprio, genuíno e autêntico ser" 308 . Essa "compreensão do ser", proveniente da relação com a morte, seria, portanto, essencial para o ser ele mesmo, que se acomodaria nesse alento pessoal. Por isso, Heidegger chama uma relação autêntica do ser humano com a morte de ser-para-morte. Aí estaria a chave para o entendimento do sentido do ser. Apenas no ser-para-morte, argumenta Cohen, "que a temporalidade do próprio ser - e o contexto historico-ontológico dentro do qual este ser encontra seu sentido último seria desvelada" ${ }^{309}$. Nada nos seria, nesse rastro, mais próprio do que a nossa própria

\footnotetext{
304 Ibidem. p. 166

305 Ibidem. p. 167

${ }^{306}$ Grifos meus.

${ }^{307}$ Ibidem. p. 170

${ }^{308}$ COHEN, Richard A. Levinas: Thinking Least about Death: Contra Heidegger. Tradução minha. International Journal for Philosophy of Religion. Vol. 60, no 1/3, Self and Other: Essays in Continental Philosophy of Religion. Springer, 2006. Disponível em: <http://www.jstor.org/stable/27646177>. Acesso: 25/09/2011. p. 23

309 Ibidem. p. 23
} 
morte. A morte, como vimos em Blanchot, inauguraria uma possibilidade: "a possibilidade da impossibilidade de qualquer existência." 310

Ainda de acordo com Cohen, diríamos que "Levinas irá nos forçar a repensar o sentido da morte ${ }^{, 311}$. Lévinas descobre que, mais apropriadamente, a questão da morte não é ontológica, mas ética. "Levinas está contestando radicalmente todo o edifício ontológico heideggariano e está oferecendo em seu lugar uma visão alternativa da ética como primado filosófico" - complementa Cohen.

Menos como um evento significativo para o próprio ser, Lévinas pensa na morte em outros termos: na verdade, como uma dinâmica relativa à morte de outra pessoa. Considerando, assim, mais a morte do outro do que a morte de si mesmo, tomando o necessário cuidado para que a morte do outro prevaleça em detrimento da de si próprio, "até o ponto culminante de morrer pelo outro" "312313 - enfatiza Cohen - "que o sujeito humano alcança sua real humanidade, e conseqüentemente a altura apropriada de um sentimento de si moral e socialmente responsável."314 Para Lévinas, uma pessoa de humanidade elevada é para-o-outro. O ser-para-o-outro, portanto, ao contrário do serpara-morte, não é somente alguém que discerniu o entendimento do seu próprio ser, mas é um ser moralmente responsável, moralmente melhor, ciente da incumbência de responder humanamente ao sofrimento do outro, "independentemente de se os outros estão ou não estão respondendo responsavelmente"315.

Eu considero que o Humano consiste precisamente em abrir-se para a morte do outro, em se preocupar com sua morte... Mas antes de mais nada, já não é mais uma questão de ir em direção ao outro quando ele está a morrer, mas de responder à mortalidade dos vivos com sua presença. Essa é a conduta ética em sua inteireza. ${ }^{316}$

Voltando à história, é isso que testemunhamos. O outrora nada ético Vassíli Andrêitch ter uma postura das mais éticas, refestelando-se no Humano a que se refere Lévinas, uma vez que encarna, ali, sob a nevasca, o ser-para-o-outro, dando a própria vida por outro ser humano. Ele "compreende que isso é a morte" - relata o narrador -

\footnotetext{
${ }^{310}$ HEIDEGGER apud COHEN, Richard A. Op. cit. p. 23

${ }^{311}$ COHEN, Richard A. Op. cit. p. 25

312 Ibidem. p. 25

${ }^{313}$ Grifos meus.

314 Ibidem. p. 26

315 Ibidem. p. 26

${ }^{316}$ LÉVINAS apud COHEN, Richard A. Op. cit. p. 26
} 
"mas não fica nem um pouco aborrecido com isso" "317. Nesse rastro, "ele é Nikita e Nikita é ele"318. A purificação, aqui, como o último estádio do movimento de fé, ou de humanização, não se dá de forma muito diferente da de Iván Ilitch. Vassíli Andrêitch condena aquele outro que ele fora, encontra a possibilidade para morte e, portanto, a liberdade, fazendo-se presente: "Ele não sabia o que eu sei agora. Agora não há erro. Agora eu sei"319.

Nikita não perece ali, é salvo, confirmando que Vassíli Andrêitch de fato morrera pela vida dele, como se aquele tivesse feito uma transferência de vida, uma doação a este em um ato de extremo altruísmo. Nikita, assim, tem a chance de morrer de velhice, entre os entes queridos, desejando partir rumo ao infinito. O Humano em Senhor e Servo se revela em todas as suas nuanças, superando a perder de vista o vigor da humanização conquistada por Iván Ilitch, visto que no conto agora trabalhado o Humano se consagra em ato à sombra do nível mais apoteótico do amor: Vassíli Andrêitch dá a vida por Nikita. O Humano joga-se na frente do outro no momento em que os fuzis estão prestes a disparar, protege o outro com seu corpo cálido, aconchegante, recolhendo-o a uma dimensão uterina, remontando, assim, à origem, ao renascimento, à ressurreição, ao formigueiro, à bem-aventurança do amor materno. À semelhança de Guerássim, que teve seus efeitos impressos na alma de Iván Ilitch, só um ser humano pode fazer de um homem Humano.

\subsubsection{Imagens}

Elizabeth Traham demonstra o quão simbólica e mística pode ser essa tardia narrativa de Tolstói. Ela aponta, por exemplo, o protagonismo que o número três exerce na história: Brekhunóv leva três mil rublos no bolso; Ele, Nikita e Baio somam três; três vezes eles se perdem e três vezes Nikita desce para procurar o caminho; eles tem três encontros ao longo da viagem: com Issái, com três camponeses em outro trenó e fazem uma parada numa casa em Gríchkino; Nikita some três vezes de vista; Brekhunóv tenta

\footnotetext{
${ }^{317}$ TOLSTÓI, Lev. A morte de Iván Ilitch e outras histórias. Tradução do russo: Tatiana Belinky. Barueri: Editora Manole, 2011. p. 174

${ }^{318}$ Ibidem. p. 174

${ }^{319}$ Ibidem. p. 174
} 
acender o cigarro por três vezes e, conseguindo na última, fuma três cigarros, deixando três restantes no maço. Há muito mais desses exemplos "cabalísticos" no texto, mas o interessante é perceber como a recorrência do número três perfaz um circulo vicioso ao copiar-se continuamente, aventando uma dinâmica da qual, aliás, eles não são capazes de evadir-se. Tudo parece mover-se em círculos na história - os personagens sempre voltam ao lugar de onde partiram, havendo uma reiteração frenética das contingências. Traham, contudo, percebe no número três uma alusão ao crucifixo. E de fato, quando Brekhunóv se deita sobre Nikita, ele pode fazê-lo ajustando o corpo em formato de cruz, esticando os braços para segurar a peliça.

O despertar religioso de Brekhunóv se torna uma peregrinação da aldeia de Kresty (Cruzes) para a Cruz, quase uma reiteração do Caminho de Cristo ao Calvário. A crise pessoal de Brekhunóv (...) se torna a experiência de um momento existencial, a culminação da luta do homem com a natureza tanto externa quanto internamente. (...)

(...) Sacrificando a si mesmo por esse homem, Brekhunóv reitera o sacrifício de Cristo, e em sua última visão Cristo vem a ele em pessoa, aceitando, assim, o sacrifício. ${ }^{320}$

Gustafson considera Senhor e Servo uma tentativa do escritor de expor em imagens sua bexperiência mais profunda com a fé. Segundo Gustafson, como A Morte de Iván Ilitch, trata-se de "dar uma forma narrativa a um dilema tolstoiano"321 que estaria enunciado no trecho a seguir, parte do texto $O$ que é minha fé? ${ }^{322}$, escrito dez anos antes da história:

Estou perdido em uma nevasca. Uma pessoa me assegura, e parece a ela também, que fogos e uma vila estão um pouco mais à frente. Mas isso só nos parece assim porque nós queremos que seja assim. Quando nós vamos em direção aos fogos eles não estão lá. Mas outra pessoa se vai através da neve. Ela dá algumas voltas, reaparece na estrada e nos grita "Não vá a nenhum lugar, os fogos estão nos seus olhos; você se perderá em qualquer lugar e irá perecer. A estrada firme

\footnotetext{
${ }^{320}$ TRAHAM, Elizabeth. L. N. Tolstoj's Master and Man - A Symbolic Narrative. Tradução minha. The Slavic and East European Journal, Vol. 7, ํo 3. American Association of Teachers of Slavic and East European Languages, 1963. Disponível em: < http://www.jstor.org/stable/305336 >. Acesso: 07/09/2011. p. 259 e 264.

${ }^{321}$ GUSTAFSON, Richard F. Op.cit. p. 201

322 В чем моя вера
} 
está bem aqui, eu estou parado em pé nela, e ela vai nos guiar para fora". Agora isso não é muito. Quando nós acreditávamos nos fogos brilhando nos nossos olhos cegos, havia sempre logo adiante uma vila, uma cabana aquecida, salvação, descanso enquanto aqui há somente uma estrada firme. Mas se dermos ouvidos ao primeiro certamente iremos congelar, enquanto que se dermos ouvidos ao segundo certamente sairemos. ${ }^{323} 324$

Mais uma vez, aqui, surge aquela personalidade conflitante, sabidamente tolstoiana, cujo embate se faz entre razão e emoção e que, em um terreno agridoce anterior, não se resolvia, gerando terrível tormento - o que foi esmiuçado em Uma confissão. Agora, no entanto, esse excerto metafórico em primeira pessoa sugere que a nevasca é um emblema da vida e, nesse contexto, surgem dois sujeitos diferentes: "um representa seus desejos, o outro a certeza do caminho; um representa sua personalidade, o outro o eu divino; um orienta para a morte, o outro para uma trilha oposta à da morte. ${ }^{, 325} \mathrm{Na}$ narrativa, contudo, segundo Gustafson, esses dois sujeitos são postos em relevo, caracterizando duas pessoas: Brekhunóv, a "personalidade" e Nikita, o "eu divino". O encontro de Brekhunóv com Nikita, assim, após uma série de despertares cumulativos do primeiro, leva Brekhunóv a encontrar o caminho para o amor da mesma forma que o próprio Tolstói descobre que sua missão "não é o ensino, a família, a arte ou ser um senhor, mas a convocação divina interior de amar seu vizinho como a si mesmo." 326

O mais interessante, entretanto, é que tal história, a partir do leimotiv nebuloso da nevasca, esse entre-lugar onde as certezas se evaporam e o que resta é a confiança no porvir, já vinha sendo delineada há tempos por Tolstói, quando em 1854, ele vivenciou uma tempestade de neve durante uma viagem de 22 horas que empreendera. Nevasca (Метель), a narrativa baseada nesse acontecimento, foi publicada em 1856 priorizando a descrição dos sinais da natureza, incluindo os animais e, sobretudo, o faro dos cavalos

\footnotetext{
${ }^{323}$ TOLSTÓl apud GUSTAFSON, Richard F. Op.cit. p. 201

${ }^{324}$ Original em russo: Я заблудился в снежную метель. Один уверяет меня, и ему так кажется, что вот они -- огоньки, вот и деревня; но это только так кажется и ему и мне, потому что нам этого хочется, а уж мы ходили на эти огоньки, и их не оказалось. А другой пошел по снегу: походил, вышел на дорогу и кричит нам: "Никуда не ездите, огоньки у вас в глазах, везде заблудитесь и пропадете, а вот крепкая дорога, и я стою на ней, она выведет нас". Это очень мало. Когда мы верили огонькам, мелькавшим в наших ошалелых глазах, была уже вот-вот и деревня, и теплая изба, и спасенье, и отдых, а тут только крепкая дорога. Но если послушаемся первого, наверно замерзнем, а если послушаемся второго, наверное выедем. ТОЛСтОЙ, Л.Н. В чем моя вера? Disponível em: <http://tolstoy.lit-info.ru/tolstoy/religiya/moya-vera/v-chem-moya-vera-1.htm>. Acesso: 28/09/2011.

${ }^{325}$ GUSTAFSON, Richard F. Op.cit. p. 201

${ }^{326}$ GUSTAFSON, Richard F. Op.cit. p. 202
} 
que, instintivamente, em oposição ao homem civilizado, encontram um caminho, uma saída, em meio ao aparente caos.

Senhor e Servo, dessa forma, foi a saída encontrada por Tolstói para o problema que vinha ruminando e amadurecendo desde a época em que percebeu que a nevasca, na realidade, era uma metáfora da vida. E a solução dessa encruzilhada, como vimos, além de deixar a natureza assumir o controle, seria amar o próximo e, se fosse o caso, dar a vida por ele - em um ato que desvela o que há de mais humano no homem.

No conto De que vivem os homens, como já mencionamos, Semion - não perdido em uma nevasca, mas envolvido por um clima invernal hostil e miserável - oferece a um homem desprovido de qualquer proteção o pouco que tem, levando-o para casa. Nessas horas - diria Mikhail (o homem salvo que, ao final, revelou-se um anjo) -, o brilho nos olhos não é apenas o efeito do humor aquoso alojado entre a córnea e o cristalino, mas, por assim dizer, um fluido de Amor e Vida sendo produzido a piscadelas.

\subsection{Três mortes}

Nos dois contos analisados anteriormente, vimos o predomínio de um Tolstói Residente, inundado por uma influência espiritual calcada na figura de Deus. Nele, entretanto, o grande mestre do autor ainda não era esse ente abstrato, saturado de amor e afeito a polêmicas, mas um homem concreto chamado J.-J. Rousseau que, não por acaso, também lhe inspirava o bem em todas as suas facetas. As conclusões a que Tolstói chega durante o percurso de Três mortes, portanto, farão eco às expostas até o momento.

Tolstói aponta que, ao lado dos Evangelhos, Rousseau foi sua maior influência desde os 15 anos de idade. Sua devoção era tanta que, além de ter devorado todos os 20 volumes do filósofo, carregava-o em seu peito, em uma corrente que continha uma imagem pendurada. Por isso, antes de adentrarmos a história do conto, percorreremos um pouco o ideário de Rousseau, baseando-nos sobretudo no celebrado Discurso sobre a origem e os fundamentos da desigualdade entre os homens, cuja ascendência sobre Tolstói é premente, na tentativa de desvendar, em parte, o que em Rousseau tanto deslumbrou o escritor russo. 


\subsubsection{Rousseau}

Em seu Discurso sobre a desigualdade, Rousseau responde a uma questão proposta em 1754 pela Academia de Dijon: "Qual é a origem da desigualdade entre os homens; ela é autorizada pela lei natural?"327. Ele dispõe o problema em termos bem simples e inteligíveis. Em um segundo momento, esses termos seriam revistos por outros pensadores, como Karl Marx ou Friedrich Hegel, tornando-se mais sofisticados. "Com o intuito de demonstrar que a sociedade não se originou na natureza, Rousseau reconstrói a história de que o homem descende de um estado associal. Onde não existe sociedade, não pode haver desigualdade entre os homens (...)." 328

Ele indaga, por exemplo, logo de início, que espécie de vida, a civil ou natural, estaria mais sujeita "a tornar-se insuportável àqueles que a usufruem"329. E conclui que, no âmago do que entendemos por civilização, estaríamos rodeados por pessoas insatisfeitas, ao passo que no seio da vida selvagem, isenta dos malefícios da existência social, ninguém nem sequer pensaria em queixar-se da vida ou em cometer suicídio. "Nada seria tão miserável quanto o homem selvagem ofuscado pelas luzes, atormentado pelas paixões" ${ }^{330}$, comenta Rousseau, não coincidentemente, à maneira de Tolstói.

Nesse rastilho, Rousseau acentua, em seu texto, a idéia de piedade. Essa idéia se aproximaria muito da concepção de amor tolstoiana, cuja maior característica residiria em fazer o bem ao próximo. Tal piedade, ou comiseração, seria maior à medida que o animal espectador se identificasse com o animal sofredor. Tal identificação (ou reconhecimento), com efeito, teria sido muito mais estreita no estado de natureza, uma vez que no estado de raciocínio o homem estaria envolto por barreiras que dificultariam seu reconhecimento com o animal que sofre. "É a razão que engendra o amor-próprio e é a reflexão que o fortalece; é ela que faz o homem ensimesmar-se; é ela que o separa de tudo quanto o incomoda e o aflige. É a filosofia que o isola",331. Schopenhauer complementaria tal proposição, afirmando que a razão é responsável também por ter

\footnotetext{
327 ANSCHUETZ, Carol. The Young Tolstoi and Rousseau's Discourse on Inequality. Tradução minha. Russian Review, Vol. 39, № 4. Blackwell Publishing, 1980. Disponível em: <http://www.jstor.org/stable/128809>. Acesso: 13/06/2011. p. 406

${ }^{328}$ Ibidem. p. 406

${ }^{329}$ ROUSSEAU. J.-J. Discurso sobre a origem e os fundamentos da desigualdade entre os homens. São Paulo: Martins Fontes, 2005. p. 186

${ }^{330}$ Ibidem. p. 187

331 Ibidem. p. 192
} 
atrelado o homem à noção de que a morte está sempre em seu encalço, tornando a vida sem sentido. Para a razão, segundo Schopenhauer, seria preferível o "não-ser": o triunfo do conhecimento sobre a Vontade de vida, que é o núcleo de nosso próprio ser, redundaria na morte.

Já o homem selvagem, por não valer-se desse cultivo da razão, entregar-se-ia "estouvadamente ao primeiro sentimento de humanidade" 332 , sem nada que pudesse refreá-lo. Tolstói fala de forma semelhante dos camponeses em Uma confissão, valorizando o "conhecimento irracional" e a fé que lhes é própria, em oposição ao "conhecimento racional" e à educação da aristocracia, que se afasta de Deus e, nesse ínterim, de uma visão da morte como algo natural - ainda que, como nos alerta Schopenhauer, a reação à ameaça de ser aniquilado seja algo inerente a todos os seres vivos; com o que, veremos adiante, Rousseau discordará.

A piedade atuaria, assim, "moderando em cada indivíduo a atividade do amor de si mesmo", concorrendo para a "conservação mútua de toda a espécie",333. Ela seria mais fundamental na conservação do gênero humano do que qualquer tipo de raciocínio. Por isso é que é nesse sentimento natural que devemos "procurar a causa da repugnância que todo homem experimentaria ao fazer o mal" ${ }^{\text {334. }}$.

Sob essa perspectiva, Rousseau atribui as desigualdades ao advento da sociedade, da civilização, uma vez que muitas das diferenças concernentes aos homens são consideradas naturais somente por obra do costume, quando, em verdade, seriam uma mácula intrinsecamente social. O ser, para Rousseau, tornou-se mau ao se tornar sociável - até por que não existiam categorias morais no estado de natureza.

Ele identifica, portanto, sugere Carol Anschuetz (1980), o estado de natureza com uma espécie de Éden. Neste, como Adão, o homem vivia sem pecados, até que um dia comeu o fruto proibido e passou à perdição. Na formulação de sua doutrina, Agostinho, observa Anschuetz, chega originalmente à conclusão de que Adão era incapaz de pecar ou de morrer, o que refuta mais tarde. Rousseau, contudo, "afirma precisamente o que Agostinho nega" ${ }^{, 35}$, ou seja, que "o homem originalmente não era capaz de pensar e, se não incapaz de morrer, pelo menos incapaz de temer a morte" ${ }^{, 336}$. Essa idéia teria uma grande influência na vida e obra de Tolstói, uma vez que ele partilhava igualmente da

\footnotetext{
332 Ibidem. p. 192

333 Ibidem. p. 192

334 Ibidem. p. 193

${ }^{335}$ ANSCHUETZ, Carol. Op. cit. p. 408

${ }^{336}$ Ibidem. p. 408
} 
noção de que o homem próximo do estado de natureza, mujiques como Nikita ou como Tio Khviédor, por exemplo, não temeriam a morte. Afinal, a morte é natural.

A sociedade civil teria surgido a partir do momento em que alguém bradou: "Isto é meu"337 - profere o filósofo -, encontrando, por sua vez, pessoas que nisso acreditaram. Fundava-se a propriedade, sendo a família, cabe dizer, uma espécie equivalente de instituição. Antes disso, à época do longevo estado de natureza, o que prevalecia era o interesse comum, nascido da necessidade mútua de bem-estar, e a igualdade que se valia, sobretudo, do fato do homem não viver em um ambiente propício a "escolhas", ao uso da razão. Vejamos, então, como Rousseau narra as mudanças ocorridas ao longo da história.

À medida que as idéias e os sentimentos se sucedem, que o espírito e o coração se exercitam, o gênero humano continua a domesticar-se, as ligações se estendem e os laços se apertam. Acostumam-se a reunir-se de fronte das cabanas ou à volta de uma grande árvore; o canto e a dança (...) tornaram-se diversão. Cada qual começou a olhar os outros e a querer ser olhado por sua vez, e a estima pública teve um preço. (...) $O$ mais belo, o mais forte, o mais hábil (...) e foi esse o primeiro passo para a desigualdade e para o vício ao mesmo tempo; dessas primeiras preferências nasceram, de um lado a vaidade e o desprezo, do outro a vergonha e o desejo (...). ${ }^{338}$

Cumpre observar que a sociedade em formação solicitava do homem novos atributos. Isso quer dizer que outros valores se implantaram e "a bondade conveniente ao puro estado de natureza já não era o que convinha"339. A piedade perdia espaço conforme crescia o apreço pelo ganho material pessoal, um propósito instituído pela civilização. A introdução da propriedade deflagrou a necessidade do trabalho e, conjuntamente, abençoou a escravidão. A miséria e a fartura passaram a co-existir.

A liberdade inerente ao estado de natureza foi sendo, nesse contexto, gradualmente alienada em prol das incongruências da vida civil, cujo maior emblema residiria no direito à propriedade. "O homem (...) passou a estar (...) sujeito a toda a natureza, sobretudo a seus semelhantes, de quem num sentido se torna escravo, mesmo

\footnotetext{
${ }^{337}$ ROUSSEAU. J.-J. Op. cit. p. 203

338 Ibidem. p. 211

${ }^{339}$ Ibidem. p. 212
} 
em se tornando seu senhor, ${ }^{, 340} 341$. O sujeito mudaria a forma de relacionar-se com as pessoas de acordo com a posição que elas ocupariam em sua escala de interesses sociais. Ele se torna prisioneiro de seus bens, limitando o alcance de suas faculdades normais por meio de "próteses". Ao promover a exclusão, a cerca separa, destrói o diálogo, aparta, inibindo as relações autênticas, o contato, o desabrochar da piedade, aniquilando tudo quanto existe em si próprio - ou seja, tudo que nos caracteriza como humanos. O ter, como um vírus, parasita o ser, nutrindo-se dele e, por conseguinte, esvaziando-o. O ser é prescindível na sociedade na qual os valores contrários à natureza humana comandam. Nesse round, enfatiza Rousseau no auge do absolutismo francês, "ser e parecer tornaram-se duas coisas totalmente diferentes"342. Isto é, "parecer" passou a ser entendido como "ter", e este a confundir-se com um falso "ser"; ao passo que o verdadeiro "ser" foi pulsar solitário, encurralado e constrangido, baforando esparsos sinais de fumaça nos confins da alma adjacente. A sociedade assistia à sua própria ruína no advento das guerras, e não havia como voltar atrás. A instituição da justiça só veio consagrar esse panorama, "destruindo", nas palavras de Rousseau, "em definitivo a liberdade natural" ${ }^{343}$, tornando a propriedade e, portanto, a desigualdade, um direito irrevogável, e relegando o gênero humano ao trabalho, à servidão e à miséria. "Vê-se facilmente como o estabelecimento de uma única sociedade tornou indispensável o de todas as outras e como, para fazer frente a forças unidas, foi preciso unir-se por sua vez. $(\ldots)^{, 344}$.

Em sua obra, Rousseau aponta como as aparências, engendradas pelas paixões fictícias, agem como combustível da sociedade, visto que os mais ricos e poderosos, em bem menor número do que a multidão de miseráveis, estimam o que podem adquirir tão somente pelo fato de que só eles podem adquirir. A felicidade desses é de tal caráter que se tornariam infelizes caso o pobre pudesse ter acesso ao que eles têm. A identificação entre o poderoso que ingere caviar (o animal espectador) e o pedinte famélico (o animal sofredor) é, portanto, nenhuma, zero, nula. O cidadão vive do juízo dos outros e daí provém o sentimento de sua própria existência, à semelhança de Iván Ilitch.

Segundo Anschuetz, nesse sentido, Rousseau enxerga o livre-arbítrio como uma fonte de corrupção. Ele "absolve o indivíduo da culpa do pecado original, enquanto

\footnotetext{
340 Ibidem. p. 218

${ }^{341}$ Grifos meus.

342 Ibidem. p. 217

343 Ibidem. p. 222

${ }^{344}$ Ibidem. p. 230
} 
imputa uma culpa coletiva ao homem em sociedade. $" 345$ Para o filósofo, a necessidade de fazer escolhas se revelou como uma perda do estado em que o homem estava isento de fazê-las. "O pecado original se tornou, para Rousseau, o pecado da escolha" ${ }^{346}$. Em Tolstói, desse modo, vemos o adulto, que é livre para escolher entre o bem e o mal, corromper-se progressivamente; e a criança que, livre da escolha, é pura tal qual o mujique. Como já vimos na análise de $A$ morte de Iván Ilitch, "A fase adulta se transforma em um estado de exílio da perda do irrecuperável Éden da infância"347. Não podemos esquecer como o livre-arbítrio leva Anna Kariênina a ser trucidada pelos ferros pesados do trem. Ou que personagens como Guerássim, Tio Khviédor ou Nikita, de fato, estão na vida à espera dos acontecimentos, com os quais lidam muito bem, incluindo o evento da morte, não podendo, até pela situação em que vivem, fazer escolhas. E que até o ancião Tolstói morre em virtude de uma escolha mal feita às raias do desespero. Semion, do conto De que vivem os homens, entretanto, faria uma escolha guiado por Deus - e esta, de tão importante, mudaria os rumos de sua vida para sempre. O mujique, quando escolhe, escolhe certo.

A gente do povo remete à infância de Tolstói, quando ele se acotovelava com os irmãos em um "formigueiro" e nada mais parecia importar. O mujique é uma criança cuja mãe é a divina natureza. Quando em Infância o narrador sofre com a morte da mãe, ele, na verdade, "lamenta a perda do estado em que ele não conhecia a tristeza" "348 observa Anschuetz. O estado de natureza, para Tolstói, assim, é onde mora o bem, o justo, o ideal, a realidade, as escolhas fáceis e simplórias, o amor, a vida, os vivos, a Mãe, Deus, o presente, o outro, o infinito e a possibilidade.

A morte, como veremos em Três mortes, não é tão somente uma forma de reaver os valores do estado de natureza por intermédio da tomada de consciência que se dá no momento da iluminação (ou purificação) da personagem; mas um modo de distinguir as pessoas no que tange ao sentido que imputam à própria vida. A experiência da morte varia conforme o grupo social em que se efetiva. O sentido da vida, a partir daí, irá se deslocar na medida em que for delineada a paisagem, cenário ou ambiente no qual está integrado o moribundo. Enquanto para o camponês, mais próximo do estado natural, esse sentido é um, para o cidadão urbano, distante desse parâmetro, ele é outro. Aos 30

\footnotetext{
${ }^{345}$ ANSCHUETZ, Carol. Op. cit. p. 410

${ }^{346}$ Ibidem. p. 411

${ }^{347}$ Ibidem. p. 411

348 Ibidem. p. 412
} 
anos, Tolstói continuaria, de maneira ainda mais pungente, a procurar o sentido da vida por meio da morte.

\subsubsection{A história}

Três mortes é um enredo costurado por três histórias em que a morte é a protagonista. Victor Chklóvski atenta-nos para o uso do paralelismo em Tolstói: “(...) Para elaborar o tema da morte, para acioná-la, ele achou necessário justapor três motivos - a morte de uma dama, a morte de um servo, a morte de uma árvore" ${ }^{, 349}$. Em comum, há a experiência da morte.

Na primeira narrativa, uma senhora da sociedade, que mais parece a contraparte feminina de Iván Ilitch, segue com sua comitiva de duas carruagens pela estrada real. Essa mulher, que o narrador compara com a criada que segue ao lado, está "nitidamente" doente. "Uma, a senhora, magra e pálida. A outra, a criada, gorda de um corado lustroso" ${ }^{\$ 50}$. Irritadiça, a senhora resmunga por qualquer coisa. É claro que vai morrer, embora continue a manter seus hábitos esnobes e aristocráticos. Um médico entra em cena e atua da mesma forma que os médicos de A Morte de Iván Ilitch. "Nenhum deles se importa comigo - disse consigo mesma"351. Ela está à beira da morte, isolada, estéril e não há nenhum indício de amor em seu horizonte. Seu refúgio está em negar a morte, embora seu diagnóstico seja dos piores: ela "não tem pulmões",352 aponta o narrador. Tolstói, também aqui, usa a doença para expressar uma condição humana. Na verdade, a senhora já está morta há tempos, pois sem pulmões é impossível respirar, assim como extraída das relações humanas é inconcebível viver. Ela não é capaz de inspirar o ar, transformá-lo e devolvê-lo à natureza. Ela não possui nenhuma relação com o mundo em que vive e, por isso, nem sequer existe. A doença, na verdade uma tuberculose, mostra-a pelo avesso. Ela deseja ir para o exterior na esperança de curar-se, mas a morte não está em algum lugar, está nela e, por essa via, não há como escapar. A possibilidade da morte desespera-a e causa-lhe vergonha, enquanto rezar, em

\footnotetext{
${ }^{349}$ CHKLÓVSKI, Victor. Os paralelos em Tolstói. Tradução do russo: André Pinto Pacheco. In: O diabo e outras histórias. São Paulo: Cosac Naify, 2000. p. 276

${ }^{350}$ TOLSTÓI, Liev. O diabo e outras histórias. Tradução do russo: Beatriz Morabito, Beatriz Ricci, Maira

Pinto. São Paulo: Cosac Naify, 2000. p. 29

351 Ibidem. p. 32

352 Ibidem. p. 33
} 
seu caso, é inútil. Tolstói, no conto, apresenta essa personagem, cuja maior expressão seria Iván Ilitch - ou seja, uma pessoa que vive de aparências, só se relaciona de forma artificial, ou como "manda o figurino", com tudo que está a seu redor e que, na verdade, está morta. "Iván Ilitch se parece com Maria Dmítrievna" - pontua Gustafson - "Ele também leva uma vida voltada para si mesmo e não entendeu a vida mortal.” 353

Já em casa, a senhora sucumbe aos poucos, enquanto, para o marido, a mãe de Maria Dmítrievna não pode encarar o fato da morte. O padre, por sua vez, exibe o pior dos vaticínios, insistindo que a mulher ainda pode curar-se com ervas. A velha, contudo, reconhece a impossibilidade de cura da filha. $\mathrm{O}$ marido, perdido diante daquele cenário que não pode encarar, foge do quarto. As crianças, brincando, não podem ver o monstro em que se transformou a mãe na iminência da morte. A morte é um monstro. E ali, mesmo após a extrema-unção, a mulher quer recorrer às ervas. A ela não é concedida a iluminação que salvaria tantas personagens de Tolstói. "Um mês depois erigiu-se um jazigo de pedra sobre a sepultura da morta. Sobre a do cocheiro ainda não havia nenhuma campa, apenas uma relva verde clara brotava do montículo de terra (...) ${ }^{, 354}$ - o narrador expõe o quão diferentes eram esses dois seres, inclusive com relação à natureza que lhes protegiam o cadáver. Paulo Bezerra sublinha o fato de que a morte da senhora “ocupa onze páginas da história [de 14 páginas], um espaço proporcional àquele que sua classe social ocupa na sociedade, portanto, repetindo na narrativa a mesma distribuição injusta de espaço que caracteriza a sociedade de castas",355.

A segunda narrativa, desse modo, se passa na movimentada isbá dos cocheiros onde para a carruagem de Maria Dmítrievna -, vívida pelo trabalho que enseja e pelo efervescente entra-e-sai de gente. O moribundo dessa vez é o cocheiro tio Khviédor. As botas novas que possui são cedidas a um segundo cocheiro, Serioga, o cocheiro da senhora, que as pede sem o mínimo de receio ou vergonha e, assim, deixa de lado seu calçado velho. Botas que, como em De que vivem os homens, não servem a um homem morto, cujos pés não podem mais tocar a terra e desgastá-las, cujo trabalho se interrompe, e que, por fim, diríamos no Brasil, vai "bater as botas". Nesse universo, fala-se da morte como se fala do almoço - ela é parte da vida. "Ninguém vai enterrá-lo

\footnotetext{
353 GUSTAFSON, Robert. Op. cit. p. 320

${ }^{354}$ TOLSTÓI, Liev. $O$ diabo e outras histórias. Tradução do russo: Beatriz Morabito, Beatriz Ricci, Maira Pinto. São Paulo: Cosac Naify, 2000. p. 45

${ }^{355}$ BEZERRA, Paulo. Tolstói contista. In: O diabo e outras histórias. São Paulo: Cosac Naify, 2000. p. 9
} 
com botas novas. ${ }^{356}$ - afirma a cozinheira. Tio Khviédor, após passá-las, contudo, pede que Serioga ponha uma lápide em seu túmulo em agradecimento ao ato de caridade. Sob esse ângulo, tio Khviédor, a despeito de aceitar sua morte, deseja ser lembrado no futuro. "Nisso, ele difere da árvore no final da história. A árvore obviamente não pode saber que está morrendo e não tem a consciência de que viveu e deve ser lembrada; ela simplesmente morre" ${ }^{357}$.

A morte de tio Khviédor está inserida na paisagem de idas e vindas da casa, sendo praticamente desejada pela cozinheira da isbá, que não vê sentido no prolongamento da vida sob o signo de tamanho sofrimento. Quando ele se vai, há, em lugar da hipocrisia elitista, um alívio explícito, auto-proclamado, uma vez que o ocorrido se dá de maneira digna. Mas a morte, para um mujique, não é a morte. E Nástia, a cozinheira, sonha que tio Khviédor ter-se-ia levantado para rachar lenha e, ajudando-a, cheio de vigor, diz que está bem. A morte não existia, e foi o que Nástia vislumbrara no sonho.

Disso, passamos à terceira narrativa, calcada no rastro da morte de uma árvore, cuja madeira irá servir para fazer uma cruz para a sepultura de tio Khviédor. Serioga, que ficara com as botas do cocheiro morto, arranca um tronco de árvore a machadadas. Ainda mais instintiva e desprovida de quaisquer sistemas de valores, a natureza não impõe resistências a essa execução acidental e, como um arranhão na pele que se cicatriza rapidamente, logo outras copas, ramalhetes, raízes e sementes irão fluidificar a ferida, reparar os poros abertos, galgar o espaço vazio; evidenciando que à luz do estado de natureza já descrito por Rousseau, uma, duas ou três mortes, que sejam, fazem parte de um conjunto maior em que, submetidas às leis do amor, serão substituídas, ou transformadas, por outras formas de vida.

Povo e natureza representam para Tolstói um duplo refúgio; o povo o faz sentir-se livre da presença dos seus pares nobres, a natureza, longe da realidade absurda, da mediocridade do mundo urbano. (...) $O$ binômio povo natureza, marca fortíssima e muito recorrente em sua obra, traz ecos inequívocos da teoria de Rousseau. ${ }^{358}$

Para Tolstói, há uma equivalência entre Deus, a natureza e o amor. Por isso seria insensato pensar em alguém temente a Deus sem que esteja em contato íntimo com a

\footnotetext{
${ }^{356}$ TOLSTÓI, Liev. O diabo e outras histórias. Tradução do russo: Beatriz Morabito, Beatriz Ricci, Maira Pinto. São Paulo: Cosac Naify, 2000. p.37

${ }^{357}$ GUSTAFSON, Robert. Op. cit. p. 319

${ }^{358}$ BEZERRA, Paulo. Tolstói contista. In: O diabo e outras histórias. São Paulo: Cosac Naify, 2000. p. 10
} 
natureza. Esta, da mesma forma, permitiria a relação do homem com sua própria natureza humana.

Fechamos o capítulo, portanto, com a análise desse conto que, a despeito de anterior às novelas $A$ morte de Iván Ilitch e Senhor e Servo, retorna a elas tanto no que se refere a seus personagens quanto no que concerne a seu tema. As idéias expressas ulteriormente parecem estar resumidas nesse conto. Iván Ilitch morre aqui, ainda que sem a tomada de consciência, Nikita está impresso na figura de tio Khviédor, e, por último, a árvore, símbolo da natureza, nos ensina como a morte pode residir em um simples abrir e fechar de olhos, no quebrar de uma onda no mar, e até no nascimento, desde que estejamos com o coração aberto para o outro. Tanto mais para o outro e menos para nós mesmos, a morte deixa de existir, visto que o que vivenciamos, de fato, é um fundir-se do homem à natureza, que deixa sem receios a noção de indivíduo para se mesclar ao macrocosmo. A representação da morte na obra de Tolstói, respondendo à pergunta que nos fizemos no início desse trabalho, se dá, sobretudo, contrariando o que diz Bakhtin, como uma forma verdadeira de celebrar a vida, no intuito de fazer que a idéia fúnebre de morte adquira novos significados, pautando-se na realidade mais profunda, até que a morte, como a entendemos comumente, já não exista. 


\section{4.}

\section{CONSIDERAÇÕES FINAIS}

Da perda da mãe ao encontro com Deus, do Estrangeiro ao Residente, do finito ao infinito, do senhor ao servo, do desespero à possibilidade, do ser-para-morte ao serpara-o-outro, do formigueiro para o mundo e, por fim, alçado aos ombros do povo, Tolstói evade-se de uma condição em que a morte deixa de ser algo insólito para se tornar uma mera passagem constituinte de nossa jornada. Ou melhor: algo que em vez de extinguir o Humano, o desperta, como no caso de Iván Ilitch; o eleva ao cume, como acontece com o senhor; e serve de parâmetro comparativo entre os mais ou menos afeitos ao meio em que vivem, como ocorre no conto Três mortes. A morte é, assim, para Tolstói, a dimensão da vida, a medida de nossa própria alma, conforme deixamos ou não de nos "haver" com ela. "Um homem livre preocupa-se com tudo, menos com a morte" 359 - disse acertadamente Spinoza. E isso significa que para esse homem pouco importa quando ou como ele morrerá, já que, à semelhança do que afirma Blanchot que balizou nossa pesquisa até aqui -, para ele a morte é possível e, nesse trânsito, inerente a sua natureza.

Tolstói sabia que só encontraria a liberdade ao desafiar o horror da morte, que poderia viver apenas superando-a, agindo, como nos parece, por meio dela. Por isso, suas personagens, sobretudo quando dialogam com a morte, precisam deslocar-se a esse nível no qual deixam de "preocupar-se" com ela, ou de experimentá-la em vida, pois "Ela não existe mais" $" 360$. Ela jamais existiu, aliás. E é justamente essa conclusão que nos devolve a capacidade de sermos o que um dia fomos antes de nos deixarmos atar pelo nó górdio da civilização (e, por conseguinte, pela morte): humanos; de sermos, afinal, o que somos - unicamente porque nenhum temor já nos aprisiona: estamos livres no ventre da espécie. Ouvimos o sibilo dos entes alados, o farfalhar da mata, o tremular da copa das árvores e fitamos os olhos na réstia de luz que, dentro em pouco, se agigantará. Somente, contudo, quando topamos com alguém que nos é semelhante que nos reconhecemos. “(...) e lhe parece que ele é Nikita e Nikita é ele, e que sua própria

\footnotetext{
${ }^{359}$ SPINOZA apud COHEN, Richard A. Op. cit. p. 22

${ }^{360}$ TOLSTÓI, Lev. A morte de Iván Ilitch e outras histórias. Tradução do russo: Tatiana Belinky. Barueri: Editora Manole, 2011. p. 104
} 
vida não está dentro de si, mas dentro de Nikita. (...) 'Nikita está vivo, quer dizer que eu também estou vivo",361.

Ao desvencilhar-se da ameaça iminente da morte, Vassili Andrêitch deixa seu fulgor humano desabrochar e, sob esse ângulo, não deseja outra coisa a não ser estar pelo outro, ser-para-o-outro, e tudo o mais que isso possa prever: dar a vida pelo servo, pelo vizinho, pela aldeia, pelo mundo. Mas não é mesmo a morte, porque a morte já não existe - proclamou Iván Ilitch -, é precisamente vivenciar a liberdade de ser um homem por inteiro, presente e sensível àquilo que, há poucos instantes, lhe evocava apenas o insípido alheio. Como outro homem, exatamente como nós, pode suscitar-nos o repúdio ou a indiferença? - Tolstói parece inquirir entre um parágrafo e outro.

Não por acaso, para Iván Ilitch a morte é alguém, é ela, é palpável, é humana. A morte de fato é humana - pois revela o que há de mais humano no homem. Em Tolstói, a morte assume outros contornos afora o corriqueiro. É um atributo para aqueles que não partilham do amor, do bem, da felicidade real, do estado de natureza - estariam, com efeito, todos mortos. É medida da quantidade de seiva vital existente em um indivíduo, visto que designa o quanto deste indivíduo já foi pervertido pelas paixões, pela vileza, pelos mortos-vivos que, especialmente nas cidades, perambulam absortos em "nada". É um convite à realidade. Em Tolstói, morre-se em vida, pois o acesso ao que há de mais essencial é, inadvertidamente, obstruído desde que nos perdemos como Adão no jardim do Éden. Dessa maneira, quanto menos se identifica com outro ser humano, desconsiderando a piedade rousseauniana, mais o homem se afasta de sua verdadeira condição, definhando perante a própria espécie. É essa identificação que dá o tom - o tônus da humanidade, cujo maior atributo é a alteridade. Se alguém morre pelo outro é, opostamente ao que possa sugerir, sinal de que vive pelo outro, reconhecendose plenamente nesse outro por meio do qual semeia a graça da humanidade. Se o homem livre de Spinoza não se preocupa com a morte, ele não se preocupa em morrer e, menos ainda, em estar morto. A morte, reiteramos, não existe nessa arena. $\mathrm{O}$ homem, portanto, vive tudo o que pode viver, até que essa vida encontre seu limite, e ele, a palpitar, ainda possa gerar o derradeiro fluido vital, oferecendo sua existência pelos que ficam. Inclusive nessa situação-limite a vida encontra para Tolstói alguma serventia humana e, por esse motivo, é vida e não morte.

\footnotetext{
${ }^{361}$ TOLSTÓI, Lev. A morte de Iván Ilitch e outras histórias. Tradução do russo: Tatiana Belinky. Barueri: Editora Manole, 2011. p. 174
} 
Enquanto investigávamos a aventura empreendida por Tolstói, também pavimentávamos um caminho. Iniciamos nossa "jornada de descoberta" ainda cegos, tateando pelo vasto universo da criação literária. Ali, algo a respeito do papel da morte no espaço relegado ao escritor começou a delinear-se graças à orientação de guias do porte de Bakhtin e Blanchot.

Mais à frente, já munidos de certo esclarecimento, fomos sondar a presença da morte na vida de Tolstói, trilha que se mostrou significativa na medida em que percebemos que sua personalidade era talhada pela morte. Razão e emoção duelaram difícil saber qual delas saiu vitoriosa. Essa contenda, no entanto, abriu-nos os olhos para dois tipos de caráter: o Residente e o Estrangeiro.

Em Uma confissão, no afã de ser apenas um, o escritor confidenciou-nos sua busca rumo a uma possibilidade para morte, o que o consagrou à fé divina. Tal busca remeteu-nos àquelas descobertas primárias, levando-nos a fechar um ciclo: Tolstói morre à procura, à cata, borbulhando de vida e sem respostas definitivas.

Em seguida, mais seguros com relação ao lugar onde pisávamos, passamos a um terreno instável outra vez: a análise de três obras literárias. Encontramos temas que se repetiam, aspectos comuns entre as obras, preocupações semelhantes, outros pensadores se fizeram audíveis, outras teorias, e a necessidade de ensinar o homem a tornar-se humano, sobretudo quando em face da morte, foi a tônica. Um triângulo foi por nós esboçado: vida - morte - vida. Essa pareceu ser a rota feita pelas personagens salvas, pela estrutura das tramas. Tolstói ansiava tornar universal o particular de suas histórias.

Os contos, contudo, demandam algo novo: uma análise maior, mais detida, mais comprometida com o presente, que jamais conseguiríamos empreender totalmente em um espaço onde estamos sujeitos ao alvorecer de cada manhã. Obtivemos, sem dúvida, um punhado de respostas no que concerne à representação da morte na obra de Tolstói, o título de nosso trabalho, ainda que tenhamos muito mais por examinar, especialmente quando nos referimos à integridade da obra do autor, formada por 90 tomos. Estamos conscientes de que não sabemos nada da vida, mas de que aprendemos, dia-a-dia, com os outros.

Às conclusões a que chega Tolstói soam simples, embora decorram de um movimento interior de densidade infinita. Esperamos que nossa empreitada possa ser, pelo menos, um lampião ou atalho para alguém que, nessa matéria, se descobrir cego. Nesse sentido, faço um agradecimento "deslocado" aos pesquisadores contemporâneos 
David Patterson, Robert Russel, Robert Gustafson e Paulo Bezerra, que, sem o saber, me encorajaram em momentos cruciais. Ao mestre Lev Tolstói, os leitores.

\subsection{Somos todos "Iváns Ilitchs"?}

\section{"Nunca houve um documento de cultura que também não fosse um documento da barbárie" 362 Walter Benjamin}

Não há como passar por todo esse rolo compressor de desumanidade funesta, ainda que daí o autor tenha feito brotar vida, sem nos abalarmos com o cenário por ele pintado: homens que são coisas; cidades governadas pelo desamor; mortos-vivos ambulantes - sendo que esses homens indiferentes e taciturnos, na verdade, somos nós mesmos, e essas metrópoles mal-cheirosas são aquelas onde habitamos, em um estádio ainda pior do que aquele descrito por Tolstói. Como agir diante da constatação de que a sociedade caminha a passos largos para um estado de morte? E como, efetivamente, lidar com a morte sob esse bárbaro panorama?

Na sociedade em que vivemos "meio a contragosto", deparamos, de um lado, com a banalização da morte que, em primeira e última análise, é a banalização da vida; e, de outro, com a falência dos sentidos, a histeria, o trágico espetáculo invariavelmente gerado pelo evento da morte, tal qual Tolstói denuncia, que encontra seu lugar ao afastar-se da "vida", do cotidiano, das pessoas, por assim dizer, sãs. A morte é banida, seu processo ocultado, procedimentos científicos baixos são cogitados - no mercado negro ou em hospitais respeitados - para evitá-la, e o luto, tão essencial ao espírito, é extinto. Não obstante, essa civilização que aniquila o homem em nome do lucro, da aparência de felicidade e da fuga do que soa desmoralizante, interdito, fazendo do medo da morte uma patologia recorrente cujos sintomas recaem em tremores, taquicardia e pensamentos intrusivos, fincou suas raízes no século de Tolstói, legando-nos o dissabor da pressa, da técnica, do antinatural e de uma noção totalmente falsa do que seria "gozar a vida", como se nossos níveis de serotonina, endorfina e adrenalina, custe o que custar, tivessem de estar, não raro, nas alturas. A "trivialidade indiferenciada" não chacinaria

${ }^{362}$ BENJAMIN. Walter. Magia e técnica, arte e política. São Paulo: Brasiliense, 1996. 
apenas sorrisos, mas empilharia corpos humanos a perder de vista, que, por sua vez, seriam endereçados às estatísticas como metas de desempenho fabril.

$\mathrm{Na}$ história, vemos que em fins do século XIX, a modernidade já mostrava a sua face, e, sobretudo, as suas vísceras, instituindo um cenário no qual os costumes mais antigos entravam em colapso com as novas tecnologias e, por sua vez, com as abruptas mudanças provenientes da revolução industrial e abundantes nas cidades. Não é à toa que a I Guerra Mundial é uma disputa de territórios por um mercado truculento que crescia em proporção geométrica. Ben Singer, dissertando sobre Nova Iorque, aponta que

A serenidade da vida do selvagem no passado acentuou a selvageria verdadeira do presente metropolitano. A colisão entre duas ordens de experiência - pré moderna e moderna - também figurou em diversas imagens que representaram as colisões reais entre carroças puxadas por cavalos - o meio tradicional de transporte - e seu substituto moderno, o bonde elétrico. ${ }^{363}$

Alguns desses cartuns ilustram carros de bonde que devastam tudo o que encontram pela frente e imediações, atropelando indivíduos e aniquilando todos os resquícios de vida humana. Ben Singer ressalta que, apesar de a morte natural também ter suscitado medo na era pré-moderna, por causa, por exemplo, da escassez de alimentos ou da difículdade de contenção das epidemias (que, por sinal, ceifaram as vidas dos filhos de Tolstói), a morte acidental, de caráter violento, repentino $e$ aleatório, parece ter recrudescido e focalizado esse medo. Nesse rastro, dos trens ${ }^{364}$

\footnotetext{
${ }^{363}$ SINGER, Ben. Modernidade, hiperestímulo e o início do sensacionalismo popular. In: O cinema e a invenção da vida moderna. São Paulo: Cosac Naify, 2004. p. 102

364 Para Dostoiévski, as ferrovias distinguem-se não só como um advento da modernidade, mas esta última e o trem surgem como facetas da morte:

“- Mas outro aparte perspicaz e incisivo! - aceitou Liébedev. - Mas, repito, não é dele que se trata agora. A nossa questão é se as fontes da vida não se enfraqueceram com o aumento das...

- Estradas de ferro! - goelou Kolia.

- Comunicações ferroviárias não, jovem e impetuoso mancebo, mas sim por causa dessa tendência da qual as estradas de ferro são, por assim dizer, a expressão mais vivaz e dinâmica. Há quem diga que elas correm aí afora com todo seu estrépito, fumaça e velocidade em prol do bem-estar da espécie humana. Eis que acode um pensador dado a elucubrações, como diria ali o meu nobre amigo e pondera: "Esta humanidade quanto mais barulhenta e comercial fica, menos paz de espírito desfruta!" "Perfeitamente, mas bendito seja o ruído dos vagões levando pão para a humanidade! Três e quatro vezes bendito, pois tal estrépito resolve a fome, ao passo que a paz espiritual não resolve o problema do estômago!" retruca violentamente um segundo pensador dialético, desses que se bamboleiam pelas assembléias; brada e se retira triunfante... A mim, porém, vil que sou, pequenino conforme me conheço, a mim não me engambelam os vagões que levam pão para a humanidade! Sim, porque os vagões que levam pão
} 
passamos aos carros que, apesar de nos granjear a independência locomotiva, são ainda mais velozes e homicidas, tanto mais se temos de manter nossos índices de felicidade artificialmente elevados - como sempre, entretanto, em nome da propriedade, jamais computamos esses dados desumanos. Carros continuam sendo fabricados aos montes, atulhando o meio urbano, salientado a desigualdade e contribuindo, como inúmeros outros fatores, para o estado de morte. A guilhotina, outra geringonça "técnica", legitimou os campos de extermínio da II Guerra, sendo a arraia miúda, os fracos, os rotulados "etnicamente inferiores" os maiores alvos dessas invenções.

Essa morte, proveniente de uma sociedade negligente com relação ao humano, portanto, já não podia ser, desse modo, naturalizada, encarada como parte da vida tal é a morte de um enfermo. E Tolstói jamais a naturalizou. Contra a banalização da morte/vida suscitada predominantemente pelas guerras - pela intolerância ao humano -, o pensador levou adiante sua teoria de resistência pacífica à violência, que consiste em não responder à violência com a violência, segundo o preceito de Cristo no Sermão da Montanha ("Não resistais ao mal"). A esse respeito, ele escreve o extenso ensaio $O$ Reino de Deus está em Vós.

Em Cossacos - Novela do Cáucaso, por exemplo, um episódio sanguinário em que sucumbe todo um exército de tchetchenos é providencial a fim de compreendermos como Tolstói encarava a questão da morte coletiva, o paroxismo desse "trivial" a que fizemos menção: "Os Cossacos, ofegando, separavam os mortos e tiravam-lhes as armas. Cada um desses tchetchenos ruivos era um ser humano, a cara de cada um tinha a sua expressão individual" 365366.

Tolstói não acreditava em massacres, nem em certa ordem de fatalidades "sem causas”, e, exatamente por isso, julgava inaceitável a morte de centenas, de milhares e até de milhões de pessoas de uma só vez. Cada indivíduo era um ser humano inigualável, com desejo, trajetória e personalidade próprios, de modo que matar a todos simultaneamente não era apenas cometer um genocídio, digamos assim, o que lhe arrepiava os pêlos, mas negar a cada um o emergir autêntico do ser que em nossas almas habita.

para a humanidade, se não estiverem cautelosamente consignados sob uma base moral, podem estar friamente excluindo da felicidade desse pão uma outra parte considerável da humanidade, aquela donde esse pão foi tirado, ora esta é muito boa! E isso há de suceder com freqüência!"DOSTOIÉVSKI, Fiódor. O Idiota. José Olímpio: Rio de Janeiro, 1951. p. 479

365 TOLSTÓ, Lev. Cossacos - Novela do Cáucaso. Tradução do russo: Nina Guerra e Filipe Guerra. Lisboa: Relógio D’Água, 2010. p. 153

${ }^{366}$ Grifos meus 
No que toca ao assombro causado pela morte individual, vemos que o filósofo romano Cícero, no século I a. C., nos instiga a cultivar uma postura afirmativa frente à morte, defendendo o que ele chama de uma "educação para morte". Segundo ele, deveríamos nos preparar desde a adolescência para o momento de partir. A maturidade, desse modo, seria uma fase de compreensão da morte, ou de sabedoria diante da vida, pois, vivendo em cada momento a nossa própria morte, conseguiríamos permanecer serenos ao deparar com a possibilidade do ocaso. A conclusão é tolstoiana: "Cada um de nós deve morrer, com efeito; hoje mesmo, talvez."367 Aceitar é superar tanto a minha morte quanto a do outro.

O sociólogo Norbert Elias nos alerta para um problema atual, ainda que tão enfatizado por Tolstói no século XIX, de que, ao negarem a morte, as pessoas também se recusam a conceder ao moribundo a afeição e ajuda de que ele tanto precisa nesse desenlace, como o fez o mujique Guerássim a Iván Ilitch. Isso decorreria do fato de que “A visão de uma pessoa moribunda abala as fantasias defensivas que as pessoas constroem como uma muralha contra a idéia de sua própria morte ${ }^{״ 368}$. Sob esse ângulo, como perscrutamos através de Tolstói e Lévinas, é preciso estar para o outro não apenas no momento de sua morte, mas no decurso de sua vida, resistindo, portanto, ao atroz desumano que nos interpela por todas as vias em uma sociedade infecunda, erigida para “coisas", não para pessoas.

Repetimos nossas indagações: Como agir diante da constatação de que a sociedade caminha a passos largos para um estado de morte? E como, efetivamente, lidar com a morte sob esse bárbaro panorama sem que engrossemos o coro de tom monocórdio dos "Iváns Ilitchs"? Não bastaria, com efeito, forjarmos uma "educação para morte" com o fito de "manter a calma", nem tampouco ficar remexendo ad infinitum no baú das causas e culpas como se a sociedade estivesse no divã de um psicanalista. A fim de que a morte participe da vida novamente, retornando ao natural, é necessário que a vida, antes, resgate a sua verdadeira natureza. A vida também se distanciou do que lhe é próprio, e vida e morte são interdependentes. Se a vida, portanto, não se tornar progressivamente mais humana, e as pessoas, sob esse aspecto, não estiverem engajadas em alimentar o amor, de modo a cultivar relações diáfanas, autênticas, éticas, ainda que os milhares de "anteparos" sociais que nos impõem nos

\footnotetext{
${ }^{367}$ CÍCERO apud HADDOCK-LOBO, Rafael. Op. cit. p. 283

${ }^{368}$ ELIAS apud FAUSTINO, Jean Carlo. A Morte de Ivan Ilitch: onde Tolstói, Dostoiévski e Norbert Elias se encontram. No prelo, 2012.
} 
façam pensar em desistir de lutar nos alvéolos de um sistema que nos soa tão alheio, não há como reavermos nosso genuíno ser.

Eis que, imaginaria o poeta concretista, a morte deita abaixo suas duas últimas letras, perdendo-as, e atrai, para sua margem esquerda, aquele $a$ pronominal que, na proa do intervalo, a seguia. Sem o pronome feminino, transforma-se em substantivo masculino: nasce $o$ amor. $\mathrm{Na}$ esteira do amor ao próximo, portanto, o importante seria resistir: "Buscar, sempre buscar!" - bramaria Tolstói. Parece ter sido isso o que, no apelo didático de suas obras, o grande autor quis ensinar-nos. 


\section{5.}

\section{BIBLIOGRAFIA}

ANSCHUETZ, Carol. The Young Tolstoi and Rousseau's Discourse on Inequality. Russian Review, Vol. 39, nº 4. Blackwell Publishing, 1980. Disponível em: $<$ http://www.jstor.org/stable/128809>. Acesso: 13/06/2011.

ARIÈS, Philippe. História da Morte no Ocidente. Rio de Janeiro: Ediouro, 2003.

BAKHTIN, Mikhail. Estética da Criação Verbal. Tradução do russo: Paulo Bezerra. São Paulo: Martins Fontes, 2006.

BAUMAN, Zigmunt. Modernidade Líquida. Rio de Janeiro: Zahar, 2001.

BENJAMIN. Walter. Magia e técnica, arte e política. São Paulo: Brasiliense, 1996.

BERNARDINI, Aurora Fornoni. O exorcismo da libertinagem em Tolstoi. $O$ Estado de São Paulo: Caderno 2, São Paulo, p. 8, 21 jan. 2001.

BEZERRA, Paulo. Alienação e Auto-Imolação em A Morte de Iván Ilitch. No prelo, 2012.

BEZERRA, Paulo. Tolstói contista. In: O diabo e outras histórias. São Paulo: Cosac Naify, 2000.

BLANCHOT, Maurice. O espaço literário. Rio de Janeiro: Editora Rocco, 2011.

BRECHT, Bertolt. Um homem é um homem. Belo Horizonte: Autêntica, 2007.

CHKLÓVSKI, Victor. Os paralelos em Tolstói. Tradução do russo: André Pinto Pacheco. In: O diabo e outras histórias. São Paulo: Cosac Naify, 2000. 
COHEN. Richard A. Levinas: Thinking Least about Death: Contra Heidegger. International Journal for Philosophy of Religion. Vol. 60, $\mathrm{n}^{\mathrm{o}} 1 / 3$, Self and Other: Essays in Continental Philosophy of Religion. Springer, 2006. Disponível em: $<$ http://www.jstor.org/stable/27646177>. Acesso: 25/09/2011.

DOSTOIÉVSKI, Fiódor. O Idiota. Rio de Janeiro: José Olímpio, 1951.

EMERSON, Caryl. The Tolstoy Connection in Bakhtin. PMLA, Vol. 100, $\mathrm{n}^{\circ} 1$. Modern Language Association, $1985 . \quad$ Disponível em: $<$ http://www.jstor.org/stable/462201>. Acesso: 20/06/2001.

FAUSTINO, Jean Carlo. A Morte de Iván Ilitch: onde Tolstói, Dostoiévski e Norbert Elias se encontram. No prelo, 2012.

FLEW, Antony. Tolstoi and The Meaning of Life. Ethics, Vol. $73 \mathrm{n}^{\mathbf{0}} 2$. The University of Chicago, 1963. Disponível em: <http://www.jstor.org/stable/2379552>. Acesso: 13/06/2011.

GUSTAFSON, Richard F. Leo Tolstoy - Resident and Stranger. New Jersey: Princeton University Press, 1986.

HADDOCK-LOBO, Rafael. O Ser e a Morte. Anuário de Filosofia São João Del-Rei, nº 10. São João Del-Rei, 2003.

HALPERIN, Irving. The Structural Integrity of the Death of Ivan Ilitch. The Slavic and East European Journal. Vol. $5 \mathrm{n}^{\mathrm{o}}$ 4. American Association of Teachers of Slavic and East European Languages, 1961. Disponível em: $<$ http://www.jstor.org/stable/305122>. Acesso: 10/06/2011.

HARRIS, Jane. A Humanist Reading of Tolstoy: The writings of Petr H. Bitsilli. Tolstoy Studies, Vol. 4, Toronto: Tolstoy Society of North America, 2001.

KIERKEGAARD, Sören. O desespero humano. In: Col. Os Pensadores. São Paulo: Victor Civita, 1979. 
LAVRIN, Janko. Tolstoy, an approach. New York: The Macmillian Company, 1946.

LUKÁCS, Georg. História e Consciência de Classe. São Paulo: Martins Fontes, 2003.

MCLEAN. Hugh. In Quest of Tolstoy. Brighton: Academic Studies Press, 2008.

MIRSKY, D. S. Tolstoy. The Slavonic and East European Review, Vol. 7. no 19. Modern Humanities Research Association, 1928. Disponível em: $<$ http://www.jstor.org/stable/4202241>. Acesso: 29/06/2011.

PACHMUSS, Temira. The Theme of Love and Death in Tolstoy's the Death of Ivan Ilyich. American Slavic and East European Review. Vol. 20, $\mathrm{n}^{\circ}$ 1. Association for Slavic, East European, and Eurasian Studies. Disponível em: $<$ http://www.jstor.org/stable/3001246>. Acesso: 10/06/2011.

PATTERSON, David. The Movement of Faith as Revealed in Tolstoi's “Confession". The Harvard Theological Review, Vol. $71 \mathrm{n}^{\mathrm{o}}$ 3/4. Harvard Divinity School, 1978. Disponível em: <http://www.jstor.org/stable/1509617>. Acesso: $15 / 07 / 2011$.

PLATÃO. Fédon. São Paulo: Editora Rideel, 2005.

QUINTERO N. C. E. Os diários de juventude de Liev Tolstói, tradução e questões sobre o gênero de diário. 2010. 155 f. Dissertação (Mestrado) - Faculdade de Filosofia Letras e Ciências Humanas, Universidade de São Paulo, 2010.

ROUSSEAU. J.-J. Discurso sobre a origem e os fundamentos da desigualdade entre os homens. São Paulo: Martins Fontes, 2005.

RUSSEL, Robert. From Individual to Universal: Tolstoy's “Smert' Ivana Il'icha". The Modern Language Review. Vol. 76 n 3. Modern Humanities Research Association, 1981. Disponível em: <http://www.jstor.org/stable/3727398>. Acesso: $10 / 06 / 2011$. 
SCHNAIDERMAN, Boris. Leão Tolstói - Antiarte e Rebeldia. São Paulo: Brasiliense, 1983.

SCHNAIDERMAN, Boris. O legado de Tolstói. Folha de São Paulo, 9 de dez. de 2000. Jornal de Resenhas, $n^{\circ}$ 69, p. 10.

SCHOPENHAUER, Arthur. Metafísica do amor, Metafísica da morte. São Paulo: Martins Fontes, 2004.

SHIRER, William. Amor e Ódio. São Paulo: Paz e Terra, 1997.

SINGER, Ben. Modernidade, hiperestímulo e o início do sensacionalismo popular. In: O cinema e a invenção da vida moderna. São Paulo: Cosac Naify, 2004.

SPENCE, G. W. Tolstoy's Dualism. Russian Review, Vol. 20, No. 3. Blackwell Publishing, 1971. Disponível em: <http://www.jstor.org/stable/126400>. Acesso: 29/06/2011.

STEINER, George. Tolstói ou Dostoiévski. São Paulo: Perspectiva, 2006.

STEPUN, Fedor. The Religious Tragedy of Tolstoy. Russian Review, Vol. 19, $\mathrm{n}^{\text {o }}$ 2. Blackwell Publishing, 1960. Disponível em: $<$ http://www.jstor.org/stable/126738 >. Acesso: 23/07/2011.

TOLSTÓI, Lev. A morte de Iván Ilitch e outras histórias. Tradução do russo: Tatiana Belinky. Barueri: Editora Manole, 2011.

TOLSTÓI, Lev. Cossacos - Novela do Cáucaso. Tradução do russo: Nina Guerra e Filipe Guerra. Lisboa: Relógio D’Água, 2010.

TOLSTÓI, Lev. Infância. Tradução do russo: Noé Silva. No prelo, 2012.

TOLSTÓI, Liev. Anna Kariênina. Tradução do russo: Rubens Figueiredo. São Paulo: Cosac Naify, 2005. 
TOLSTÓI, Liev. O diabo e outras histórias. Tradução do russo: Beatriz Morabito, Beatriz Ricci, Maira Pinto. São Paulo: Cosac Naify, 2000.

TOLSTÓI, Liev. Os últimos dias. Tradução do russo: Anastassia Bytsenko, Belkiss J. Rabello, Denise Regina de Sales, Graziela Schneider e Natalia Quintero. São Paulo: Penguin Companhia das Letras, 2011.

TOLSTÓI, Liev. Resposta à resolução do Sínodo de 20-22 de fevereiro de 1901 e às cartas recebidas nessa ocasião. In: Padre Sérgio. Tradução do russo: Beatriz Morabito. São Paulo: Cosac \& Naify, 2001.

TOLSTOY, Alexandra. Tolstoy and the Russian Peasant. Russian Review, Vol 19, $\mathrm{n}^{\mathrm{o}}$ 2. Blackwell Publishing, 1960. Disponível em: $<$ http://www.jstor.org.stable/126737>. Acesso: 11/08/2011.

TOLSTOY, Lev Nikolayevich. A Confession. Tradução do russo: Louise Maude e Aylmer Maude. Disponível em: <http://www.ccel.org/ccel/tolstoy/confession.pdf $>$. Acesso: 15/06/2011.

TOLSTOY, Lev. Boyhood. Tradução do russo: C.J. Hogarth. Disponível em: $<$ http://www.gutenberg.org/files/2450/2450-h/2450-h.htm>. Acesso: 14/07/2011.

TRAHAM, Elizabeth. L. N. Tolstoj's Master and Man - A Symbolic Narrative. The Slavic and East European Journal, Vol. 7, $\mathrm{n}^{\circ}$ 3. American Association of Teachers of Slavic and East European Languages, 1963. Disponível em: < http://www.jstor.org/stable/305336 > . Acesso: 07/09/2011.

TROYAT, Henri. Tolstoy. New York: Grove Press, 1967.

ТОЛСТОЙ, Л.Н. В чем моя вера? Disponível em: <http://tolstoy.litinfo.ru/tolstoy/religiya/moya-vera/v-chem-moya-vera-1.htm>. Acesso: 28/09/2011. 